\title{
ANALISIS PEMAHAMAN KEWANGAN DALAM KALANGAN MAHASISWA AKADEMI PENGAJIAN ISLAM UNIVERSITI MALAYA
}

\section{Financial Understanding Analysis among Academy of Islamic Studies' Undergraduates in University of Malaya}

\author{
Ana Shakirah Md Sapir ${ }^{1}$ \\ Zainul Abidin Abdul Halim²
}

\begin{abstract}
With manyuniversitystudents receiving formalfinancialeducation, more individual have become significant understanding on their own money management. As a result, they able to successfully manage their own tuition fees, cost of living and entertainment without their parents' guidance. This paper explored financial understanding of undergraduates at Academy of Islamic Studies University of Malaya (APIUM). Specifically, this paper investigated their demographic profiles and its relationship with their understanding on zakāh, takaful and free-interest loans offered by Islamic financial institutions. In addition, this paper also investigated on their spending behaviour. Characteristics such as field of study, source of education funds, education financing and their spending priority were examined to determine the main drivers behind the receiving of zakāh, subscribing
\end{abstract}

\footnotetext{
1 PhD Candidate, Faculty of Business and Accounting, University of Malaya, 50603, Kuala Lumpur, Malaysia, anashakirah.kdu@gmail.com

2 PhD Candidate, Faculty of Usuluddin, Abdelmalek Essaadi University, Tetouan, Morocco, zaynulislam94@gmail.com
} 
monthly takaful, engaging in interest-based loans as well as their spending behavior. We assumed that financial literacy defined by OECD has become our underlying framework for this paper. Findings indicated that undergraduates with full sponsored by their family have different view about receiving zakāh funds, subscribing takaful, engaging in free-interest loan, and spending on entertainment cost. It is expected that this study would be expanded to more undergraduates who come from rich family backgrounds. It is expected that this study may help university to develop appropriate program of financial education suitable for undergraduates of various demographic profiles including those who come from rich family.

Keywords: financial literacy, financial knowledge, financial understanding, undergraduates, zakāh, riba, takaful, PTPTN

\section{PENGENALAN}

Pemahaman kewangan di negara-negara barat sudah lama dibincangkan. Ini kerana pemahaman kewangan yang jitu dapat meningkatkan tahap kewangan individu menjadi lebih baik kerana semua keperluan dan kehendaknya dapat dipenuhi tanpa perlu merasai kerisauan untuk membelanjakan wang mereka. Mereka bukan sahaja dapat membelanjakan wang pada masa sekarang, tetapi juga mereka sentiasa memastikan kewangan yang mencukupi pada masa mereka ditimpa musibah. ${ }^{3}$ Walau bagaimanapun, pemahaman mengenai pengurusan kewangan peribadi bagi mereka yang beragama Islam terbatas. Ia masih dapat dilihat bahawa individu Muslim masih lagi tidak menjalankan kewajipan dalam

3 The Consumer Financial Protection Bureau, 'Measuring Financial WellBeing: A Guide to Using the CFPB Financial Well-Being Scale,' https://www. consumerfinance.gov/data-research/research-reports/financial-well-being-scale/, dicapai pada 13 Ogos 2016. 
menunaikan zakat ${ }^{4}$ dengan sempurna, tidak melanggani takaful ${ }^{5}$ dan juga tidak tahu membezakan pinjaman yang ditawarkan oleh bank konvensional ${ }^{6}$ dan juga perbankan Islam. Contohnya, Kementerian Kewangan Malaysia telah mengumumkan jumlah simpanan dalam perbankan Islam Malaysia bernilai RM 115.1 bilion pada tahun 2019, jadi dianggarkan sejumlah RM2.9 bilion zakat simpanan dapat dikutip oleh institusi zakat seluruh Malaysia $(2.5 \% \mathrm{x}$ RM 115.10 bilion). ${ }^{7}$ Malangnya, Pusat Pungutan Zakat Wilayah Persekutuan melaporkan bahawa hanya sejumlah RM 46 juta sahaja yang berjaya dipungut daripada sumber harta berupa wang simpanan di bank, ${ }^{8}$ memberi gambaran hanya $1.6 \%$ dari jumlah anggaran zakat harta simpanan wang di bank yang berjaya dikutip oleh Pusat Pungutan Zakat Wilayah Persekutuan (RM 46

$4 \quad$ Zakat berasal dari perkataan Bahasa Arab yang bererti bertambah. Dari segi istilah fiqh pula ia adalah nama khas bagi harta dengan kadaran tertentu yang diambil dari bentuk harta yang tertentu dengan cara tertentu untuk diberikan kepada golongan tertentu. Lihat: Ibrāhim Ibn Muḥammad al-Bajurī, Hāshiyah al-Bajurī 'ala Sharh al- 'Allāmah Ibn Qașìm al-Ghazzī 'ala Matn Abī Shuja', vol. 2, ed. Maḥmūd Ṣāliḥ al-Hadīdī (Jeddah: Dar al-Minhaj, 2016), 313.

5 Takaful berasal dari perkataan Bahasa Arab al-kafalah (الكفالة). Perkataan ini memberi makna tanggungjawab memberi nafkah, atau mematerai perjanjian, atau memberi jaminan. Setelah itu, perkataan al-kafalah dibentuk sesuai acuan kata tafā 'ul (تفَاعَل) menjadi lafaz takaful yang membawa erti jaminan dan tanggungjawab dari kedua-dua pihak yang mematerai perjanjian. Konsep takaful ini bukan hanya terbatas kepada pengurusan kewangan, bahkan ia juga terdapat dalam politik dan kemasyarakatan. Lihat Muḥammad bin Aḥmad al-Șāliḥ, al-Takāful al-Ijtimā' 'i fì al-Sharī'ah al-Islāmiyyah (Arab Saudi: Kerajaan Arab Saudi, 1993), 14. Akta Takaful 1984 yang mendefinisikan takaful sebagai "suatu skim yang berasaskan persaudaraan, perpaduan dan bantuan bersama yang menyediakan pertolongan dan bantuan kewangan kepada peserta jika diperlukan yang dengannya peserta samasama bersetuju untuk memberi sumbangan bagi maksud itu." Makna yang sama juga didapati dalam definisi takaful yang dinyatakan oleh Jabatan Kemajuan Islam Malaysia (JAKIM): "Takaful ialah, suatu skim yang berdasarkan prinsip ta 'awun, jamin menjamin atau bantuan bersama. Ia memberikan perlindungan bersama aset dan harta serta menawarkan perkongsian risiko bersama sekiranya salah seorang ahlinya mengalami kerugian." Lihat laman sesawang Jabatan Kemajuan Islam Malaysia (JAKIM), 'e-Muamalat: Portal Rasmi Muamalat dan Kewangan Islam,' Jabatan Kemajuan Islam Malaysia, http://e-muamalat.islam.gov.my/ms/soalanlazim/takaful, dicapai pada 26 September 2019.

6 Keuntungannya berasaskan faedah yang dikenakan ke atas jumlah pinjaman yang diberikan kepada peminjam.

7 Ministry of Finance (MOF), Malaysian Economic Outlook 2019 (Putrajaya, Malaysia: Ministry of Finance, 2019).

8 Pusat Pungutan Zakat (PPZ MAIWP), Laporan Kewangan Zakat 2005-2017 (Kuala Lumpur, Malaysia: PPZ MAIWP, 2019) 
juta / RM 2.9 bilion). Individu Muslim juga dilihat tidak mempunyai tabung simpanan jangka masa yang efektif untuk kecemasan atau kemalangan. Ini dapat dilihat daripada statistik 2017 yang dilaporkan oleh Malaysian Takaful Association bahawa $85 \%$ individu Muslim di Malaysia tidak melanggani takaful sebagai persediaan kecemasan dan tabungan masa depan. ${ }^{9}$ Walaupun alasan utama tidak melanggan takaful pada minimum harga RM 50 sebulan kerana peningkatan kos sara hidup yang tinggi, tetapi apabila perbandingan dibuat dengan langganan Netflix ${ }^{10}$ oleh $78 \%$ rakyat Malaysia, ${ }^{11}$ pengkaji lebih cenderung untuk mengatakan perbelanjaan kewangan individu masa kini lebih terarah kepada hiburan.

Perbincangan mengenai pemahaman kewangan individu juga dapat diperhatikan dengan gelagat individu membuat pinjaman. Laporan Bank Negara pada tahun 2016 menunjukkan bahawa masyarakat Malaysia berhutang sekitar RM 940.4 bilion atau 88\% daripada Keluaran Dalam Negara Kasar dan ia semakin meruncing pada tahun 2019. ${ }^{12}$ Di dalam laporan yang sama, Bank Negara melaporkan pinjaman perumahan adalah tujuan utama bagi $56 \%$ peminjam, diikuti dengan $16 \%$ individu membuat pinjaman kenderaan manakala selebihnya pinjaman peribadi bagi menyelesaikan permasalahan ketidakmampuan membayar hutang kad kredit yang tinggi. Walaupun The Organisation for Economic Co-operation and Development $(O E C D)^{13}$ melaporkan $97 \%$ penduduk Malaysia mempunyai gelagat kewangan yang baik iaitu menyisihkan sumber pendapatan yang diterima setiap bulan untuk

$9 \quad$ Malaysian Takaful Association, 2017 Report (Kuala Lumpur: Malaysian Takaful Association, 2017).

10 Rangkaian 'video streaming' dari Amerika Syarikat yang telah mengembangkan capaiannya ke 130 buah negara di seluruh dunia, dan 78\% rakyat Malaysia dilaporkan teruja menggunakan khidmat Netflix ini.

11 Malaysian Communications and Multimedia Commission's (MCMC), '2018 Internet Users Survey' https://www.mcmc.gov.my/skmmgovmy/media/General/ pdf/Internet-Users-Survey-2018.pdf, dicapai pada 1 Mei 2020.

12 Laporan Bank Negara Malaysia 2016, 2017, 2018, 2019. https://www.bnm.gov. my/index.php?ch=en_publication\&pg=en_ar\&lang=en\#tab1, dicapai pada 1 Mei 2020 .

13 Satu organisasi antarabangsa yang ditubuhkan pada tahun 1961 bagi meransang kemajuan ekonomi antrabangsa dan usahasama perdagangan antara negara negara anggota OECD. Lihat laman sesawang rasmi The Organisation for Economic Cooperation and Development (OECD), 'Who we are,' https://www.oecd.org/about/, dicapai pada 6 Ogos 2020. 
disimpan, ${ }^{14}$ namun, penemuan OECD pada tahun 2012 ini dibidas oleh para penganalisa yang memfokuskan kajian mereka terhadap tabiat kewangan penduduk Malaysia. Pengkaji lepas yang memfokuskan kajian mereka di Malaysia mendapati simpanan di dalam akaun simpanan peribadi untuk melayakkan seseorang bagi kemudahan memohon kad kredit atau membuat pinjaman peribadi. Lebih membimbangkan, 47\% generasi muda di Malaysia yang bergelar eksekutif muda sekitar lima tahun yang lepas, ${ }^{15}$ mempunyai jumlah hutang kredit kad tinggi yang digunakan untuk pembelian yang tiada manfaat untuk jangka masa panjang seperti pembelian kasut berjenama, beg tangan yang mahal, gajet terkini dan barang runcit. ${ }^{16}$ Selain itu, ramai generasi muda yang baru memulakan pekerjaan atau perniagaan, terperangkap dengan hutang peribadi yang tinggi disebabkan tekanan untuk berbelanja besar bagi majlis perkahwinan. ${ }^{17}$ Situasi kewangan pemuda dan pemudi Malaysia ini bertambah genting apabila mereka dikurniakan cahaya mata yang lebih memerlukan belanja kewangan. ${ }^{18}$

Para pengkaji kewangan sedar bahawa pemahaman mengenai kewangan mempunyai hubungan signifikan dengan tabiat kewangan. ${ }^{19}$ Maka, ramai pengkaji memfokuskan kajian mereka kepada kumpulan mahasiswa yang menuntut di Institusi Pengajian Tinggi. Pemilihan mahasiswa sebagai responden sasaran kajian disebabkan pemahaman kewangan mahasiswa dapat menentukan kuasa pengguna bagi masa akan datang. ${ }^{20}$ Kebiasaannya,

14 Atkinson, Adele. \& Messy. Flore-Anne, 'Measuring Financial Literacy: Results of the OECD/International Network on Financial Education (INFE) Pilot Study,' OECD Working Papers on Finance, Insurance and Private Pensions, no. 15 (Paris, France: OECD Publishing, 2012), 15.

15 Asian Institute of Finance, 'Understanding Gen Y: Bridging the Knowledge Gap of Malaysia's Millennial,' http://www.aif.org.my/about-aif, dicapai pada 1 Mei 2020 .

16 Zafar U. Ahmed., Ishak Ismail., M. Sadiq Sohail., Ibrahim Tabsh \& Hasbalaila Alias, 'Malaysian Consumers' Credit Card Usage Behavior,' Asia Pacific Journal of Marketing and Logistics, vol. 22/4 (2010): 528.

17 Ho, Fiona, 'Wedding Loans: The Worst Decision You Could Make,' https://www. imoney.my/articles/wedding-loans-the-worst-decision-you-could-make, dicapai pada 1 Mei 2020.

18 Sinar Harian, 'Masalah Kewangan Punca Kes Cerai Tinggi,' https://www. sinarharian.com.my/article/29843/berita/Nasional/Masalah-kewangan-puncakes-cerai-tinggi, dicapai pada 1 Mei 2020.

19 Puspita, G. \& Isnalita, 'Financial Literacy: Pengetahuan, Kepercayaan Diri dan Perilaku Keuangan Mahasiswa Akuntasi,' Riset \& Jurnal Akuntansi, vol. 3/2 (2019): 117.

20 Felipe, Ceribeli, \& Lana, 'Investigating the Level of Financial Literacy of University Students,' RACE, vol. 16/2 (2017): 845. 
selepas tamat pengajian, sebahagian besar mahasiswa akan bergelar eksekutif muda yang bergaji tetap. ${ }^{21}$ Bagi graduan beragama Islam, faktor mempunyai pendapatan tetap setiap bulan ini memudahkan mereka untuk membuat keputusan kewangan sama ada untuk menyimpan atau membelanjakan wang tersebut. ${ }^{22}$ Jumlah simpanan mereka nanti menentukan kelayakan mereka untuk membayar zakat dan juga langganan takaful. Manakala tabiat berbelanja dengan pendapatan yang ada bakal menjadi indikator sama ada mereka cenderung untuk membuat pinjaman atau tidak. ${ }^{23}$ Bagi mahasiswa Islam, pengetahuan untuk membezakan di antara pinjaman konvensional atau pinjaman berasaskan perbankan Islam adalah kritikal. Ini berdasarkan kepada tegahan Islam untuk tidak terjebak di dalam transaksi kewangan yang berasaskan riba. ${ }^{24}$

Walaupun demikian, sebilangan para pengkaji kewangan juga tidak sependapat untuk mensasarkan mahasiswa sebagai responden kajian. Mereka berhujah dengan mengatakan bahawa mahasiswa adalah golongan yang masih melalui proses pembelajaran, sedangkan pemahaman kewangan memerlukan seseorang mempunyai pengalaman hands-on untuk mengendalikannya. ${ }^{25}$ Golongan mahasiswa juga dilihat tidak mempunyai pendapatan tetap setiap bulan dan kuasa membuat keputusan dalam pengurusan kewangan juga agak terhad kepada jumlah dana pendidikan yang diterima saja. ${ }^{26}$ Pilihan mahasiswa Islam sebagai responden mengenai kefahaman zakat juga dilihat tidak sesuai kerana mereka bukanlah golongan pembayar zakat harta, ${ }^{27}$ dan sebahagian

21 Lusardi, S. Mitchell \& Curlo, 'Financial Literacy among the Young: Evidence and Implications for Consumer Policy,' The Organisation for Economic Cooperation and Development (OECD) https://www.dartmouth.edu/ alusardi/ Papers/Financial_literacy_young.pdf, dicapai pada 1 Mei 2020.

22 Yakob, Janor, \& Khamis, 'Tahap Literasi Kewangan dalam Kalangan Pelajar Universiti Awam: Kajian di Universiti Kebangsaan Malaysia,' Jurnal Personalia Pelajar, vol. 18/1 (2015): 75.

23 Cude, Lawrence, Lyons, Metzger, LeJeune, Marks, \& Matchtmes, 'College Students and Financial Literacy: What They Know and What We Need to Learn,' (Paper presented, Eastern Family Economics and Resource Management Association, Conference 2006, Austin, Texas).

24 Merujuk kepada Riba al- Nasi'ah iaitu faedah yang dikenakan ke atas pinjaman.

25 Frijins, Gilbert, \& Red, 'Learning by doing: The Role of Financial Experience in Financial Literacy,' Journal of Public Policy, vol. 34, no. 1 (2013): 123.

26 Abdullah, Mohammed, Salleh, Rashid, \& Kamal, 'Financial Literacy among UiTM's Students,' Journal of Applied Environmental and Biological Sciences, vol. 7/58 (2017): 32.

27 Wahid, Mohd Noor, \& Ahmad, 'Kesedaran Membayar Zakat: Apakah Faktor Penentunya?’ International Journal of Management Studies, vol. 12/2 (2005): 171-189. 
besar masih lagi tidak melanggani takaful sebagai tabungan. Malah mereka juga masih tidak tahu untuk membezakan antara pinjaman konvensional dan perbankan Islam kerana tiada pengalaman membuat pinjaman perumahan dan pinjaman kenderaan. Namun, pengkaji berpendapat golongan mahasiswa adalah kumpulan sasaran terbaik untuk meramalkan tabiat berbelanja dalam tempoh terdekat. Kajian mendalam mengenai profil demografik mahasiswa jurusan pengajian Islam bakal mendedahkan maklumat baru tahap kefahaman kewangan mereka yang sememangnya berbeza dengan mahasiswa Islam jurusan lain. Ini kerana sekiranya pemahaman kewangan mereka dapat dikenal pasti, maka pihak yang berautoriti masih mempunyai kesempatan untuk merangka pendidikan kewangan yang sesuai dengan tahap pemahaman mereka dan gaya hidup mereka. Dengan cara ini, mereka dapat diberi panduan untuk menggunakan pendapatan dengan cara berhemah, mendahulukan kewajipan berzakat sekiranya berlayakan, mempunyai tabungan kecemasan melalui langganan takaful dan juga membuat pinjaman dalam situasi yang benar-benar diperlukan sahaja.

Bagi mencapai objektif ini, struktur perbincangan dalam artikel ini disusun seperti berikut. Topik seterusnya mengenal pasti karakteristik dan profil demografik mahasiswa jurusan pengajian Islam dan perbezaan gaya hidup mereka berkemungkinan mempengaruhi cara mereka menguruskan kewangan mereka, diikuti dengan perbincangan mengenai pemahaman kewangan yang lahir daripada ilmu kewangan yang dipraktikkan dalam kehidupan seharian sehingga mempengaruhi tabiat menyimpan dan membelanjakan wang. Data dan metod kajian digambarkan kemudiannya dan diikuti dengan perbincangan mengenai dapatan kajian. Artikel ini diakhiri dengan ringkasan kepada semua dapatan kajian, limitasi kajian dan mengemukakan beberapa cadangan untuk dimanfaatkan oleh pihak pentadbir universiti.

\section{MAHASISWA DAN PEMAHAMAN KEWANGAN}

\section{Definisi Mahasiswa}

Mahasiswa adalah gelaran bagi seseorang yang menempuhi pembelajaran formal di peringkat universiti atau kolej universiti. ${ }^{28}$ Golongan mahasiswa juga terkenal sebagai golongan terpelajar atau golongan intelektual kerana proses pembelajaran yang dilalui itu mempersiapkan mereka untuk menjadi pemimpin

28 Kurniawan, 'Pengertian Mahasiswa menurut para ahli beserta peran dan fungsinya.' https://www.gurupendidikan.co.id/pengertian-mahasiswa/, dicapai pada 1 Mei 2020. 
masyarakat pada masa hadapan. ${ }^{29}$ Ciri-ciri mahasiswa yang berbeza dengan pelajar sekolah adalah dari segi kemasukannya (intake) di universiti adalah secara sukarela dan berbayar, tidak seperti sekolah yang kemasukannya adalah wajib dan tidak memerlukan sebarang bayaran. Mahasiswa menguruskan sendiri masa untuk belajar dan aktiviti ko-kurikulum tanpa memerlukan keizinan ibu bapa lagi. Mereka juga bebas mengatur jadual kelas mereka sendiri mengikut jurusan yang mereka minati asalkan memenuhi jumlah jam kontak kuliah yang telah ditetapkan. Mahasiswa juga tidak memerlukan lagi orang dewasa untuk menyusun atur jadual kelasnya. Mereka juga perlu bertanggungjawab sepenuhnya terhadap apa jua tindakan berisiko yang mereka ambil seperti tidak menghadiri kuliah melebihi 40\%. Di samping itu, satu dewan kuliah secara normalnya melebihi 100 orang mahasiswa, jumlah yang berbeza di sekolah yang rata ratanya satu kelas tidak boleh melebihi daripada 40 orang. ${ }^{30}$ Golongan mahasiswa juga terdiri daripada golongan belia ${ }^{31}$ yang berusia di antara 18 tahun sehingga 23 tahun.

\section{Mahasiswa Islam}

Mahasiswa yang beragama Islam ialah mereka yang berpegang kepada akidah yang murni dan melaksanakan kewajipan dan beramal dengan rukun Islam yang diperintahkan agama seperti menunaikan kewajipan solat fardhu, berpuasa pada bulan Ramadhan, membayar zakat, menunaikan haji dan umrah, berbuat baik kepada kedua ibu bapa, menghormati guru dan ulama', serta ihsan kepada binatang. ${ }^{32}$ Islam amat mementingkan umat Islam menuntut ilmu pengetahuan, jadi mahasiswa Islam bukan sahaja sekadar perlu menuntut ilmu fardhu 'ain tetapi juga ilmu-ilmu yang bersangkutan dengan teknologi, astronomi,

29 Aladdin, Y.H. \& Ahmad, A., 'Tahap Literasi Kewangan di Kalangan Mahasiswa,' (Kertas kerja, International Conference on Global Education V Global Education 2017, Commonwealth and Cultural Diversity, Universitas Ekasakti, Padang. 1011 April 2017), 2374.

30 Kementerian Kesihatan Malaysia, 'Mengharungi kehidupan di kolej dan universiti,' http://www.myhealth.gov.my/mengharungi-kehidupan-di-kolej-danuniversiti/, dicapai pada 1 Mei 2020.

31 Kementerian Belia dan Sukan dalam 'Draf Kajian Semula Dasar Belia Negara' mentakrifkan belia sebagai mereka yang berumur di antara 15 hingga 25 tahun'. Lihat https://www.ippbm.gov.my/jdownloads/Penyelidikan/kajian-literasi-kompu ter-di-kalangan-belia-luar-bandar.pdf, dicapai pada 1 Mei 2020.

32 Kaizan Nazlan, 'Mahasiswa Islam : Erti Seorang Muslim,' https://www.slideshare. net/kaizan/mahasiswa-islam-erti-seorang-muslim, dicapai pada 9 Ogos 2020. 
perubatan, perniagaan dan juga kewangan bagi memastikan kewajipan dan ibadah sebagai orang Islam dapat dilaksanakan dengan lebih sempurna. ${ }^{33}$

\section{Mahasiswa Pengajian Islam}

Manakala mahasiswa pengajian Islam, pada asasnya, berbeza dengan mahasiswa Islam yang mengambil jurusan yang tiada kaitan dengan pengajian Islam. Pengkaji lepas berpendapat bahawa mahasiswa pengajian Islam, secara dasarnya, mengikuti pengajian Islam yang merangkumi pengajian Akidah Islamiyyah, Syariah dan Tasawwuf agar dapat meneruskan legasi perjuangan para Nabi dan Rasul, menyeru manusia untuk melakukan kebaikan, serta mencegah manusia dari melakukan kejahatan. ${ }^{34}$ Berbanding dengan mahasiswa yang beragama Islam tapi mengikuti jurusan yang berbeza seperti perniagaan, perubatan, kejuruteraan atau Bahasa, mahasiswa pengajian Islam mempunyai tanggungjawab yang lebih berat untuk memastikan pengajian mereka dapat membentuk sahsiah peribadi mereka dan pemikiran yang konsisten dengan ajaran Islam kerana mereka bakal menjadi pendakwah dan sumber rujukan agama. ${ }^{35}$ Sedikit kesilapan yang dilakukan oleh mahasiswa pengajian Islam mampu memberi kesan besar dan membentuk pandangan negatif masyarakat kepada mereka. ${ }^{36}$ Mereka juga sering dipandang rendah oleh masyarakat moden disebabkan mereka dianggap sebagai golongan yang selalu ketinggalan dalam arus kemodenan dan kemajuan sesebuah negara. ${ }^{37}$ Dalam konteks kewangan,

33 Mohd Shahrizal Nasir, ' Keperluan, bukan pilihan,' https://www.hmetro.com.my/ addin/2020/01/536781/keperluan-bukan-pilihan, dicapai pada 10 Ogos 2020.

34 Abdul Rahman Hamzah \& Wan Fahmie Abdillah, 'Persepsi Pelajar Sarjana Muda Sains serta Pendidikan (Pengajian Islam) terhadap tanggungjawab kepimpinan dakwah di Universiti Teknologi Malaysia,' http://eprints.utm.my/id/eprint/10741/, dicapai pada 9 Ogos 2020.

35 Jaafar, Abd Ghani, Tibek, Mohd Nor, Gunardi, Ismail, Darmi, Mat Saad, Idrus, Abdullah, Ishak, Ismail \& Sulaiman, 'Cabaran Institusi Pendidikan Pondok Serta Impak Terhadap Pembentukan Diri Pelajar,' Journal of Islamic, Social, Economics and Development (JISED), 2/6 (2017): 224.

36 Ahmad Johari Sihes, Abdul Rahim Hamdan, Jamaluddin Ramli \& Nor Salis Samingan, 'Pengaruh pengetahuan agama ke atas amalan agama dan gaya hidup mahasiswa Islam Universiti Teknologi Malaysia,' http://eprints.utm.my/id/ eprint/384/1/AhmadJohariSihes2006_Pengaruhpengetahuanagamakeatasamalan. pdf, dicapai pada 9 Ogos 2020.

37 Muhamad Razak Idris, 'Agamawan pemangkin majukan negara,' https://www. bharian.com.my/kolumnis/2016/07/178595/agamawan-pemangkin-majukannegara, dicapai pada 6 Ogos 2020. 
pemahaman kewangan mahasiswa Islam sangat terhad diperbincangkan dalam kalangan sarjana kewangan. Jadi, adalah tidak adil sekiranya mereka dianggap sebagai golongan yang terbelakang berbanding dengan mahasiswa Islam yang lain semata-mata cara pemikiran, pergaulan dan gelagat mereka yang berbeza dengan cara hidup mahasiswa Islam yang dibesarkan dengan gaya hidup moden. Dua faktor utama di bawah ini telah dikenal pasti oleh pengkaji terdahulu ${ }^{38}$ yang menghuraikan keunikan latar belakang mahasiswa pengajian Islam dan dilihat mempengaruhi pengurusan kewangan mereka:

\section{i) Cara Keluarga Menguruskan Kewangan}

Kebanyakan mahasiswa pengajian Islam dibesarkan dalam keluarga yang anggota keluarga wanita tidak diberatkan dengan kewajipan mencari nafkah untuk menyara keluarga seperti anggota keluarga lelaki. Sejajar dengan itu, anggota keluarga lelaki lebih banyak membuat keputusan kewangan di dalam keluarga masing-masing berbanding dengan wanita. ${ }^{39}$ Maka tidak hairan sekiranya dalam keluarga mahasiswa pengajian Islam ini, anggota keluarga lelaki lebih ke hadapan dalam isu-isu berkaitan kewangan berbanding dengan anggota keluarga wanita kerana lelaki bertindak sebagai pencari nafkah untuk menyara keluarga, ${ }^{40}$ pembayar zakat fitrah untuk dirinya dan tanggungannya, ${ }^{41}$ dan juga menguruskan pembelian barang-barang keperluan keluarga. ${ }^{42}$ Ia berbeza dalam suasana yang keluarga mengamalkan gaya hidup moden kerana anggota keluarga lelaki dan wanitanya bertindak untuk bersama-sama mencari nafkah dan melibatkan anak-anak dalam perbincangan mengenai kewangan keluarga. Dalam keluarga moden, bapa selalunya menguruskan hal berkaitan dengan perancangan masa depan keluarga, manakala ibu menguruskan

38 Pengkaji tersebut ialah Md Sapir, Ana Shakirah, 'Islamic Financial Literacy among Malaysian Undergraduates,' Lihat halaman 22-38 untuk keterangan lanjut.

39 Agarwalla, Barua Jacob, \& Varma, 'Financial Literacy among Working Young Adults in Urban India,' World Development, vol. 67 (2015): 101.

40 Jabatan Bantuan Guaman, 'Nafkah Orang Islam,' http://www.jbg.gov.my/images/ doc/risalah/nafkah-org-islam.pdf, dicapai pada 6 Ogos 2020.

41 Hasrul Hassan, 'Kewajipan Zakat Fitrah seorang perempuan,' https://www. hasrulhassan.com/2014/07/kewajipan-zakat-fitrah-seorang-perempuan.html, dicapai pada 6 Ogos 2020.

42 Sharifah Zahidah, 'Coretan spontan tentang Syria,' https://dkraj1 zlwu7.cloudfront. net/budaya-suami-di-syria-beli-keperluan-dapur-adalah-ketua-keluarga-bukanisteri/, dicapai pada 6 Ogos 2020. 
perbelanjaan kewangan seharian. ${ }^{43}$ Anak-anak yang dibesarkan dengan cara ibu dan bapa yang bekerjasama memainkan peranan dalam kewangan keluarga lebih cenderung untuk menguasai ilmu kewangan kendiri berbanding dengan mereka yang memusatkan keputusan kewangan untuk ditentukan oleh ketua keluarga saja. ${ }^{44}$

\section{ii) Latar Belakang Pendidikan}

Di peringkat sekolah menengah, pelajar jurusan pengajian agama bukan sahaja dilengkapkan dengan ilmu agama, tetapi juga diajar ilmu kemahiran hidup bagi tujuan menyara diri sendiri dan keluarga tanpa mengharapkan bantuan orang lain. ${ }^{45}$ Pembelajaran yang banyak berpusat di kawasan pedalaman dan desa menyebabkan kebanyakan mahasiswa dari latar belakang pengajian Islam tradisional mempunyai pemahaman kewangan kontemporari yang terhad. Lokasi pengajian yang jauh daripada hub kewangan dan perdagangan antarabangsa seperti Kuala Lumpur menyebabkan mereka tidak didedahkan dengan terminologi kewangan antarabangsa yang kompleks. ${ }^{46}$ Maka diandaikan bahawa cara mahasiswa ini memahami kewangan adalah berbeza jika dibandingkan dengan rakan mahasiswa mereka yang dibesarkan di kota metropolitan. ${ }^{47}$

Maka, tidak hairanlah sekiranya tabiat pengurusan kewangan mahasiswa pengajian Islam perlu dirangka dengan mengambil kira faktor latar belakang mereka. Cara pendekatan literasi kewangan yang berbeza perlu dilaksanakan agar ia dapat diadaptasikan oleh mahasiswa ini dengan lebih efektif.

43 Bigda, 'Mom Leads the Way in Shaping Financial Skills,' articles.chicagotribune. com/2011-06-17/news/sc-cons-0616-started20110617_1_financial-skillsfinancial-literacy-financial-education, dicapai pada 1 Mei 2020.

44 Sabri, Cook \& Clinton, 'Financial well-being of Malaysian college students,' Asian Education and Development Studies, vol. 1/2 (2012): 164.

45 USAID INDONESIA, 'Analysis of the current situation of Islamic Formal Junior Secondary Education in Indonesia,' http://datatopics.worldbank.org/hnp/ files/ edstats/IDNdprep07.pdf, dicapai pada 1 Mei 2020.

46 ITS Education Asia (2016), 'The importance of Business English in Hong Kong,' www.itseducation.asia/business-english.html, dicapai pada 1 Mei 2020.

47 PWC, 'Developing a Global Financial Centre for Social Impact Investment Research Report City of London Corporation,' www.cityoflondon.gov.uk/ economicresearch, dicapai pada 1 Mei 2020. 


\section{Sumber Kewangan untuk Membiayai Pembelajaran}

Ibu bapa yang mempunyai perancangan kewangan yang efektif pasti memikirkan tabungan untuk masa depan anak-anaknya. Ini terbukti bahawa mahasiswa yang mempunyai tabungan yang secukupnya untuk membiayai pengajian memperolehi skor pemahaman kewangan yang lebih tinggi berbanding dengan mereka yang dibiayai dengan bantuan biasiswa atau pinjaman pendidikan. ${ }^{48}$ Ibu bapa yang memahami bahawa bantuan kewangan pendidikan yang benar-benar terhad di samping kos pendidikan yang semakin mahal selalunya akan mengambil tindakan untuk menabung anak sejak berusia 15 hari. ${ }^{49}$ Bagi mahasiswa yang menjurus kepada pengajian Islam, dana untuk membiayai pendidikan mereka di universiti dikatakan bersumberkan zakat, ${ }^{50}$ maka para pelajar yang mempunyai pengetahuan kewangan Islam yang formal pastinya lebih memahami bahawa dana zakat yang diberikan kepada mereka adalah untuk mereka manfaatkan di dalam hal yang berkaitan dengan pelajaran mereka sahaja. Bagi ibu bapa yang mempunyai pendapatan yang kukuh, adalah perkara biasa bagi mereka untuk membiayai pengajian tinggi anakanak sendiri tanpa mengharapkan ihsan orang lain, dan ramai yang membuat pengeluaran EPF bagi membiayai pendidikan anak-anak. ${ }^{51}$ Didapati juga sekiranya tabungan simpanan pendidikan dan dana zakat tidak mencukupi, ibu bapa mahasiswa pengajian Islam dikatakan memilih untuk membuat pinjaman daripada ahli keluarga dan saudara mara sebagai langkah terakhir untuk mencukupkan pembiayaan pendidikan anak-anak mereka di universiti. ${ }^{52}$

48 Education planner.org (2011), 'Why save for your child's future?' www. educationplanner.org/parents/why-save.html, dicapai pada 1 Mei 2020.

49 Mahalingam, 'Saving and investing for a child's education is imperative with everrising cost,' https://www.thestar.com.my/business/business-news/2012/06/02/ saving-and-investing-for-a-childs-education-is-imperative-with-everrising-cost, dicapai pada 1 Mei 2020.

50 Infopelajar2u, 'Derma siswa melanjutkan pelajaran ke IPT tempatan Zakat Kedah,' https://www.infopelajar2u.com/derma-siswa-melanjutkan-pelajaran-keipt-tempatan-zakat-kedah/, dicapai pada 1 Mei 2020.

51 KWSP, 'Finance your higher education: Pursue a brighter future for you or your children, $\quad$ https://www.kwsp.gov.my/member/withdrawals/partial/education, dicapai pada 1 Mei 2020.

52 W. Mahmud, 'Pengurusan hutang yang efektif,' http://e-muamalat.islam.gov.my/ images/pdf-bahan-ilmiah/pengurusan_hutang_yang_efektif_baru.pdf, dicapai pada 1 Mei 2020. 


\section{Jenis Pinjaman untuk Membiayai Pembelajaran}

Pinjaman daripada keluarga dan saudara mara menjadi pilihan utama ibu bapa mahasiswa Islam kerana berkemungkinan ibu bapa mahasiswa tersebut tidak mempunyai harta yang boleh dicagarkan ${ }^{53}$ di institusi kewangan Islam bagi membolehkan pinjaman bank dilakukan, atau pun mereka khuatir pinjaman peribadi terdedah kepada unsur-unsur riba, maysir dan gharar. ${ }^{54}$ Apabila tiada pendedahan secara langsung kepada pinjaman peribadi melalui institusi kewangan Islam, maka mahasiswa Islam jarang berinteraksi dengan pihak bank. Maka, mereka tidak dapat membezakan antara pinjaman konvensional dan pinjaman dari institusi kewangan Islam. Selain itu, pilihan ramai mahasiswa sekiranya sudah habis berikhtiar untuk mendapatkan sumber kewangan ialah PTPTN. Pinjaman PTPTN ini menjadi pilihan mahasiswa pengajian Islam kerana caj perkhidmatannya sangat rendah berbanding pinjaman pendidikan dari institusi kewangan yang lain dan bebas dari unsur-unsur riba, maysir dan gharar. ${ }^{55}$ Pinjaman pendidikan PTPTN membiayai pendidikan di peringkat pengajian tinggi melibatkan tiga juta peminjam yang bernilai RM 56 billion dari awal pelancarannya sehingga lah tahun $2019 .{ }^{56}$

\section{Cara Mahasiswa Membelanjakan Sumber Kewangan Pendidikan}

Cara mahasiswa membelanjakan sumber kewangan dapat memberi gambaran mengenai pemahaman kewangan mereka. Sumber kewangan yang terhad perlu diutamakan untuk pembiayaan yuran pengajian terlebih dahulu. ${ }^{57}$ Bagi

53 Pinjaman bercagar adalah pinjaman yang menggunakan aset seperti rumah atau kereta untuk dicagar kepada pihak bank. Sekiranya peminjam gagal membayar balik pinjaman, bank boleh menarik balik aset yang dicagarkan itu. Lihat iMoney. my, 'Cagaran dan Penjamin Pinjaman Peribadi,'https://www.imoney.my/articles/ cagaran-dan-penjamin-pinjaman-peribadi, dicapai pada 1 Mei 2020.

54 Md Sapir, Ana Shakirah, 'Islamic Financial Literacy among Malaysian Undergraduates,' (Master Dissertation, Faculty of Business and Accountancy, University of Malaya, Kuala Lumpur, 2016): 2.

55 Thilinadan, 'Culas bayar PTPTN khianati pelajar B40,' https://www.bharian.com. my/kolumnis/2019/07/587459/culas-bayar-ptptn-khianati-pelajar-b40, dicapai pada 1 Mei 2020.

56 Patho Rohman, 'Amalan terdahulu punca PTPTN berhutang RM 40 billion,' https://www.bharian.com.my/berita/nasional/2019/05/564646/amalan-terdahulupunca-ptptn-berhutang-rm40-bilion, dicapai pada 1 Mei 2020.

57 College Choice, 'What are the major expenses for students?' https://www. collegechoice.net/college-life-3/what-are-the-major-expenses-for-students/, dicapai pada 1 Mei 2020. 
mahasiswa yang terpaksa menyewa di luar kampus, sumber kewangan yang ada perlu dibahagikan antara pembayaran yuran, sewa rumah serta kos pengangkutan dan juga makanan. ${ }^{58}$ Kehidupan pelajar yang menyewa di luar kampus lebih memeritkan sehingga ada di antara mereka terpaksa bekerja separuh masa bagi menampung kewangan yang tidak mencukupi. Apabila mengkaji tabiat berbelanja dalam kalangan belia, difahamkan kos hiburan perlu diambil kira oleh para pengkaji kewangan. ${ }^{59}$ Hiburan ${ }^{60}$ seperti pembelian pakaian dan kasut ${ }^{61}$ bagi mengikuti trend hijabister ${ }^{62}$ terkini dan juga langganan mobil data ${ }^{63}$ bagi membolehkan langganan Netflix untuk melayari filemfilem terkini ketika bosan menunggu bas adalah antara perkara yang dikenal pasti ditafsirkan oleh mahasiswa sebagai keperluan dan bukannya hiburan. Kegagalan untuk membezakan antara kos sara hidup dan hiburan ini dilihat menyebabkan mereka selalu berada dalam situasi tertekan kerana terpaksa mencari sumber kewangan yang lebih bagi menampung gaya hidup mereka. ${ }^{64}$

\section{Jurusan Pengajian}

Jurusan pengajian juga dapat meramalkan gelagat kewangan seseorang. Mahasiswa yang menjadi responden dan mengambil jurusan kewangan selalu memperolehi skor yang tinggi dalam soal selidik ilmu kewangan

58 Caldwell, 'Choosing between On and Off Campus Living Options,' https://www. thebalance.com/choosing-between-on-and-off-campus-living-options-2386191, dicapai pada 1 Mei 2020.

59 FinAid, 'Defining education - related expenses,' FinAid Page,' http://www.finaid. org/educators/higher-education-expenses.phtml, dicapai pada 1 Mei 2020.

60 University of Nebraska-Lincoln terkenal kerana memperkenalkan banyak program liburan bagi mahasiswa mereka menggunakan perkataan vibrant yang sama definisi dengan hiburan seperti yang dinyatakan di atas. Lihat Student Involvement University of Nebraska-Lincoln, 'Your Vibrant Hub!' https://communityvitality. unl.edu/create-vibrant-communities, dicapai pada 1 Mei 2020. Ia berbeza dengan konsep edutainment yang menjadikan hiburan sebagai sumber pendidikan bagi menarik minat pelajar.

61 Zafar U. Ahmed., Ishak Ismail., M. Sadiq Sohail., Ibrahim Tabsh \& Hasbalaila Alias, 'Malaysian Consumers' Credit Card Usage Behavior,' 528-544.

62 Wanita Islam bertudung yang berpakaian menutup aurat tetapi pada masa yang sama mereka mahu selalu kelihatan mengikuti fesyen terkini yang tidak menjadi kebiasaan bagi norma dan adatnya.

63 Mobil data adalah benda yang membuatkan telefon pintar itu tetap online dan internet dapat digunakan walaupun ketiadaan wifi.

64 Sabri \& Zainuddin, 'Kos Sara Hidup Mahasiswa UPM,' Jurnal Pengguna, vol. 8/29 (2018): 117-135. 
korporat berbanding dengan mereka yang bukan dari jurusan kewangan di universiti. ${ }^{65}$ Bapa yang berpendidikan tinggi di dalam bidang kewangan dan juga mempunyai tabiat membaca buku-buku yang berkaitan dengan kewangan dilihat mempengaruhi kefahaman mahasiswa mengenai kewangan dan selalunya berminat untuk menyambung pengajian di dalam bidang kewangan juga dan terlibat dalam memformulasi polisi kewangan. ${ }^{66}$ Mahasiswa yang dibesarkan dalam keluarga yang menjalankan perniagaan (family business) dilihat lebih mempunyai tahap kefahaman kewangan yang tinggi berbanding rakan-rakan sebaya mereka yang sama-sama mengambil jurusan kewangan di universiti. ${ }^{67}$ Mahasiswa yang mempunyai banyak masa dengan ibunya yang berpengetahuan kewangan, mereka ini biasanya mempunyai kecekapan pengurusan kewangan yang tinggi dan mahir mengendalikan perbelanjaan dengan efektif menggunakan komputer berbanding dengan mereka yang menghabiskan masa dengan bapa. Anak-anak yang cenderung mengikuti langkah si ibu selalunya lebih meminati untuk menyambung pengajian dalam bidang profesional kewangan dan mengemudi sektor korporat. ${ }^{68}$ Mahasiswa Islam dalam jurusan pengajian Syariah dilihat lebih cenderung untuk memahami perbankan Islam dan takaful ${ }^{69}$ berbanding mereka yang mengikuti kuliah usuluddin atau pengajian dan pendidikan Islam.

\section{PEMAHAMAN KEWANGAN}

Pemahaman kewangan ialah mengenai keupayaan seseorang individu itu untuk menyerap konsep-konsep kewangan, pasaran saham dan operasinya, serta juga undang-undang yang berkaitan dengan pelaburan dan kewangan dalam

65 Lantara \& Kartini 'Financial Literacy Among University Students: Empirical Evidence from Indonesia,' Journal of Indonesian Economy and Business, vol. 30/3 (2015): 247.

66 Clark, 'Why Fathers matter to their children's literacy,' National Literacy Trust, http://www.literacytrust.org.uk/assets/0000/0770/Father_review_2009.pdf, dicapai pada 1 Mei 2020.

67 Shim, Xiao, Barber, \& Lyons, 'Pathways to Life Success: A Conceptual Model of Financial Well-being for Young Adults,' Journal of Applied Developmental Psychology, vol. 30/6 (2009): 708.

68 Calamato 'Learning Financial Literacy in the Family,' (Master Dissertation, Department of Sociology, San José State University, California, USA, 2010), 57.

69 Md.Sapir@Md.Shafik, \& Wan Ahmad, 'Financial literacy among Malaysian Muslim undergraduates', Journal of Islamic Accounting and Business Research. ahead-of-print (2020). 10.1108/JIABR-10-2017-0149. 
tabiat membuat keputusan kewangan sehariannya. ${ }^{70}$ Manakala, terdapat juga pengkaji mengatakan seseorang itu mempunyai tahap pemahaman kewangan yang mendalam sekiranya ia selari dengan perancangan kewangan yang jitu seperti pengurusan aliran tunai yang sihat, mempunyai simpanan kewangan kecemasan dan pengurusan hutang yang efektif. ${ }^{71}$ Para pengkaji juga menemui orang yang mempunyai pemahaman kewangan yang tinggi amat gemar berhutang bagi melakukan pelaburan berisiko. ${ }^{72}$ Ilmu kewangan yang tinggi dilihat dapat memandu gelagat mereka untuk berhutang bagi perkara-perkara yang mempunyai manfaat jangka panjang dan membawa pulangan yang tinggi seperti pelaburan dalam pasaran saham, terlibat dalam pelaburan hartanah atau melabur untuk mengembangkan perniagaan ke peringkat antarabangsa. ${ }^{73}$ Mereka juga gemar untuk mendapatkan perkhidmatan konsultasi kewangan profesional bagi tujuan perancangan pelaburan. ${ }^{74}$

Di dalam perancangan kewangan keluarga pula, ilmu kewangan yang tinggi mampu menjadikan ketua keluarga merancang tabiat berbelanja dan menguruskan penggunaan kredit dengan lebih baik. Contohnya, pengkaji lepas menemui tabiat positif ibu bapa kepada pelajar institusi pengajian tinggi yang berhutang untuk membeli insuran pendidikan anak-anak mereka seawal mereka dilahirkan, menerapkan kehidupan berkeluarga yang sederhana dan elakkan dari melakukan pembaziran, menghadkan penggunaan kredit kad untuk hal-hal penting sahaja dan juga membayar bil-bil tepat pada masanya. ${ }^{75}$ Apabila individu yang mempunyai tahap kewangan yang tinggi ini berinteraksi dengan masyarakat yang juga mempunyai pemahaman kewangan yang jitu, mereka lebih cenderung untuk mengamalkan bukan sahaja perkongsian rezeki, tetapi berkongsi risiko kewangan bagi mengurangkan ketidakstabilan

70 Wan Ahmad \& Md Sapir, 'Women and Zakat on Banking Deposits,' (Selangor: Persatuan Ulama Malaysia, 2019), 305.

71 Hung, Parker, \& Yoong, 'Defining and Measuring Financial Literacy,' Working Paper, no. 708 (Santa Monica: Social Science Research Network, 2009), 2.

72 Robb \& Sharpe, 'Effect of Personal Financial Knowledge on College Students' Credit Card Behavior,' Journal of Financial Counseling and Planning, vol. 20/1 (2009): 25.

73 Kiyosaki, Increase your financial IQ: Get Smarter with Your Money (New York, USA: Hachetter Book Group, 2008), 100.

74 Robb, Barbiaz \& Woodyard, 'The Demand for Financial Professionals' Advice: The Role of Financial Knowledge, Satisfaction, and Confidence,' Financial Service Review, vol. 21 (2012): 291.

75 Norvilitis \& MacLean, 'The Role of Parents in College Students' Financial Behaviours and Attitude,' Journal of Economic Psychology, vol. 31 (2010): 55. 
ekonomi dalam masyarakat setempat. $^{76}$ Sikap baik seseorang terhadap pengurusan kewangan ini membuatkan ia cenderung membuat penilaian sama ada pengurusan kewangan itu adalah baik untuk dirinya, keluarganya atau masyarakatnya,${ }^{77}$ di samping tabiat pengurusan kewangan yang baik pula berkaitan rapat dengan kelaziman pengurusan kewangan yang efektif seperti merekodkan perbelanjaan harian dan membayar bil bil tepat pada masanya. ${ }^{78}$

Secara umumnya, definisi pemahaman kewangan individu amat berkait rapat dengan kerangka literasi kewangan yang terkenal dan merangkumi lima dimensi iaitu kesedaran kewangan, ilmu kewangan, kemahiran kewangan, sikap terhadap pengurusan kewangan dan tabiat pengurusan kewangan. ${ }^{79}$ Kelima-lima dimensi ini telah diperkenalkan oleh OECD. Tujuan utama OECD memperkenalkan rangka konsep kewangan ini ialah untuk mengukur tahap literasi kewangan termasuk pemahaman mengenai kewangan. Seseorang itu dilihat mampu memahami konsep-konsep kewangan dengan mudah sekiranya dilengkapi dengan ilmu kewangan yang tinggi.

\section{Kepentingan Literasi Kewangan}

Berdasarkan kajian para pengkaji di atas, ia boleh dikatakan bahawa tahap kewangan yang stabil dan baik amat bergantung kepada pemahaman individu dalam mencerna ilmu dan kemahiran kewangan supaya dapat mengubah sikap dan tabiat individu tersebut menjadi lebih positif dalam aktiviti merancang, mengurus dan menyimpan dan membelanjakan wangnya. ${ }^{80}$ Kesedaran kewangan seseorang individu amat berkait rapat dengan tahap kelaziman, kebiasaan dan kesediaan seseorang untuk melaksanakan setiap transaksi kewangan. ${ }^{81}$ Contohnya, seseorang itu dikira mempunyai tahap kesedaran

76 Anjali Sane, 'Financial Literacy: Challenges for Indian Economy,' Journal of Commerce \& Management Thought, vol. 5/3 (2014): 475-487.

77 Luksander Alexandra, Beres, Daniel, Huzdik, Katalin, \& Nemeth, Erzsebet, 'Analysis of the Factors that Influence the Financial Literacy of Young People Studying in Higher Education,' Public Finance Quarterly, vol. 3 (2014): 220.

78 The Consumer Financial Protection Bureau, 'Measuring financial well-being: A guide to using the CFPB Financial Well-Being Scale.'

79 Adele Atkinson \& Flore-Anne Messy, Measuring Financial Literacy, 2.

80 Remund, 'Financial Literacy Explicated: The Case for a Clearer Definition in An Increasingly Complex Economy,' The Journal of Consumer Affairs, vol. 44/1 (2010): 279.

81 Coffman, An Environmental Scan of Challenges, Criticism, Practices and Opportunities: Harvard Family Research Project (Harvard, U.S: Communications Consortium Media Center, 2002), 1. 
kewangan yang tinggi sekiranya dia menyimpan wang, mengurangkan perbelanjaan yang tidak bermanfaat dan mengurangkan tabiat kewangan yang buruk. $^{82}$

Kepentingan mempunyai ilmu kewangan yang mantap adalah tiang kepada pemahaman kewangan individu. Tanpa ilmu kewangan, seseorang itu tidak mampu mengerti tentang konsep asas pengurusan kewangan seperti aset, liabiliti, modal dan pinjaman. ${ }^{83}$ Apatah lagi bagi seorang individu Muslim, ilmu kewangan Islam yang tinggi dapat membuatkan seseorang individu itu memahami zakat, takaful dan pinjaman tanpa riba dengan lebih mantap. Ini disebabkan zakat adalah satu kewajipan bagi Muslim yang berharta, langganan takaful adalah satu instrumen yang efektif untuk tabungan masa depan dan kecemasan, manakala pinjaman tanpa riba dapat menggalakkan aktiviti individu untuk melabur atau berniaga. Contohnya, apabila seseorang itu memahami kepentingan menyimpan wang untuk kecemasan dan kegunaan jangka masa panjang, maka ia dapat menggerakkan dirinya untuk melanggani produk takaful berbanding melanggan hiburan seperti Netflix. Bagi memastikan langganan takaful dibayar tepat pada masanya, ia lebih cenderung untuk membayarnya dengan menggunakan kaedah pemotongan gaji setiap bulan secara automatik ke institusi takaful pilihannya. Ini kerana pemahaman kewangan didapati seiring dengan perkembangan teknologi maklumat. ${ }^{84}$

\section{Pemahaman Mengenai Kewangan Islam}

Kebanyakan kajian lepas mengenai pemahaman kewangan Islam adalah berkisar kepada sikap dan persekitaran individu Muslim terhadap produkproduk yang ditawarkan oleh institusi kewangan Islam. Contohnya, 81 pegawai bank didapati dapat meningkatkan pemahaman mengenai kewangan Islam sekiranya mereka berfikiran positif terhadap produk-produk kewangan Islam dan berfikiran negatif terhadap produk produk kewangan konvensional, mempunyai ibu bapa yang juga melanggan produk-produk kewangan Islam, mempunyai pengamalan kewangan berhemah, terlibat dalam pelaburan sekuriti secara langsung dan juga mempunyai ilmu pengurusan harta dalam

82 fastweb, '31 Money saving tricks for students,' http://www.fastweb.com/financialaid/articles/the-31-money-saving-tricks-for-students, dicapai pada 20 Julai 2016.

83 Kiyosaki, Increase your financial IQ: Get Smarter with Your Money, 40.

84 Chaulagain, 'Contribution of Financial Literacy to behaviour,' Journal of Economics and Behavioral Studies, vol. 7/6 (2015): 61. 
Islam. ${ }^{85}$ Kajian juga dijalankan di Qatar mendapati pemahaman mengenai kewangan Islam perlu sejajar dengan pengetahuan agama yang merangkumi tauhid dan tasawwuf. ${ }^{86}$

Pengamal kewangan yang membuat kajian mengenai ekonomi rumahtangga dan kewangan keluarga berpendapat, kajian yang hanya memberi keutamaan dalam memahami produk-produk kewangan yang berbentuk perbankan, pelaburan dan komersial tidak selari dengan apa yang diamalkan dalam merancang kewangan keluarga ${ }^{87}$ Sejajar dengan pengetahuan kewangan Islam dalam kalangan orang awam, ia perlu berkisar mengenai zakat, langganan takaful, juga produk pinjaman peribadi dan kad kredit yang bebas dari unsur riba. Ini kerana orang awam yang bukan terlibat secara profesional dalam industri kewangan Islam seperti pelabur saham, pegawai bank, agen takaful atau ahli perniagaan yang memerlukan pengetahuan teknik kewangan yang tinggi. ${ }^{88}$

Mengambil kira definisi pemahaman kewangan seperti yang diterangkan sebelum ini, kaedah untuk menguji tahap pemahaman seseorang mengenai kewangan Islam juga perlu selari dengan pengamalan kewangan Islam yang didasari oleh keimanan yang jitu.

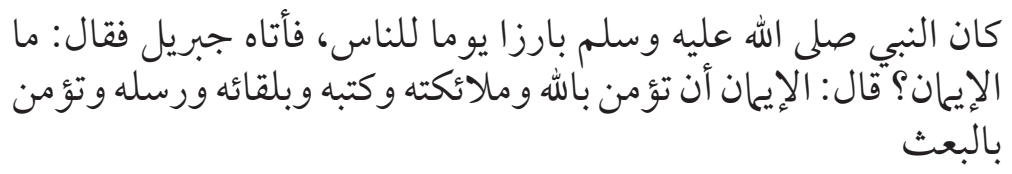

"Suatu hari Nabi SAW berada di tengah orang ramai, lalu Jibril mendatangi Baginda lalu berkata: "Apakah iman?" Nabi menjawab: "Iman adalah engkau beriman dengan Allah, para malaikat, kitab-kitab, pertemuan denganNya, para rasul, serta beriman dengan hari kebangkitan..." 89

85 Abdullah \& Anderson, 'Islamic Financial Literacy among Bankers in Kuala Lumpur,' Journal of Emerging Economies and Islamic Research, vol. 3/2 (2015): 2.

86 Amiirah Raffick, 'Islamic Financial Literacy among QFIS Students' (Master Dissertation, Qatar Faculty of Islamic Studies, Hamad Bin Khalifa University, 2015), 13.

87 Remund, 'Financial Literacy Explicated: The Case for a Clearer Definition in an Increasingly Complex Economy,' 279.

88 Md.Sapir@Md.Shafik, \& Wan Ahmad, 'Financial literacy among Malaysian Muslim undergraduates.'

89 Muḥammad Ibn Ismāil al-Bukhārī, Șaḥịh al-Bukhārī, vol. 1 (Bayrūt: Dār Ṭawq al-Najāh, 1422H), 19, 'Bāb Su'āl Jibrīl,' no. hadis 50. 
Ini disebabkan, dalam proses untuk memiliki harta, seseorang Muslim perlu sedar bahawa harta yang dimiliki itu semuanya adalah milik Allah SWT, dan dia hanyalah diamanahkan untuk mentadbir dan menguruskan harta tersebut mengikut syarak. Allah SWT berfirman di dalam al-Quran:

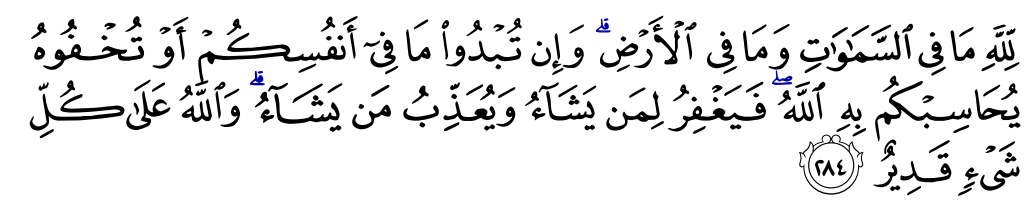

"Segala yang ada di langit dan yang ada di bumi adalah kepunyaan Allah. Dan jika kamu menzahirkan apa yang ada di dalam hati kamu atau kamu memyembunyikannya, nescaya Allah akan menghitung dan menyatakannya kepada kamu. Kemudian Dia mengampunkan bagi sesiapa yang dikehendakiNya dan menyeksa sesiapa yang dikehendakiNya (menurut undangundang peraturanNya) Dan (ingatlah), Allah Maha Kuasa atas tiap-tiap sesuatu."

(Surah al-Baqarah, 2: 284)

Inilah perbezaan utama antara falsafah kewangan Islam dan doktrin kewangan barat yang melihat pemilikan harta adalah hak mutlak individu ${ }^{90}$ dan untuk kajian kali ini, pengkaji memfokuskan kepada tiga aspek pemahaman mengenai kewangan Islam iaitu pemahaman mengenai zakat, takaful, dan pinjaman tanpa riba. Ia dijelaskan seperti berikut:

\section{Pemahaman Mengenai Zakat}

Pembayaran zakat berhubungkait dengan kedudukan kewangan seseorang yang beragama Islam dan dikenali sebagai salah satu daripada Ibadah al-Maliyyah alIjtimayiah. ${ }^{91}$ Jadi, setiap individu Muslim yang awam perlu mengetahui bahawa zakat adalah isu Al-Ma'lum Minal Din bi Dharurah yang membawa maksud setiap individu yang beragama Islam perlu mengetahui kewajipan membayar zakat dalam Islam. ${ }^{92}$ Secara asasnya dari sudut syarak, semua umat Islam

90 Hassan, An Islamic Paradigm in Economics: Vision and Mission (Kuala Lumpur, Malaysia: Institut Kefahaman Islam Malaysia, 2012), 59.

91 M. Shaarani, Ahmad, M. Noor, \& Muhammad, 'Zakat dalam Mazhab Shafi'i: Analisis Kaedah Istinbat Hukum.' (Kertas kerja, 1st Kedah International Zakat Conference, Lembaga Zakat Negeri Kedah, Kedah, 6 Ogos 2019), 883.

92 Al-Akiti, Akidah Ahli Iman (Selangor: Galeri Ilmu Sdn. Bhd., 2019), 15. 
perlu mengetahui bahawa zakat merupakan salah satu daripada rukun Islam. ${ }^{93}$ Umat Islam sama ada berharta atau tidak berharta sekalipun, perlu mengetahui bahawa zakat terbahagi kepada dua kategori iaitu zakat fitrah ${ }^{94}$ dan zakat harta. Manakala, secara amnya, zakat harta dikenakan kepada individu Islam yang merdeka. ${ }^{95}$ Nilai minima harta yang dimiliki secara sempurna oleh individu itu dan melayakkannya membayar zakat dipanggil nisab pada kadar $2.5 \%$ atau bersamaan dengan 85 gram emas. ${ }^{96} \mathrm{Hawl}$ itu bermaksud telah berlalu satu tahun pemilikan harta yang mencukupi nisab itu. ${ }^{97}$ Kajian lepas mendapati 100 individu Islam yang menjawat jawatan pengurusan dan profesional di sektor awam tidak mempunyai pemahaman mengenai zakat (nisab, hawl) walaupun mereka patuh kepada arahan membayar zakat pendapatan. ${ }^{98}$ Ia sesuatu yang membimbangkan kerana ilmu dan informasi mengenai zakat sebenarnya dapat memastikan mereka dapat memahami tujuan sebenar pembayaran zakat serta menunaikan tanggungjawab membayar zakat pada jumlah dan waktu yang tepat seperti yang dikehendaki oleh syarak.

93 Ahmad, \& Mahadi, 'Sustainable Development Goals and The Role of Zakat' (Kertas kerja, 1st Kedah International Zakat Conference, Lembaga Zakat Negeri Kedah, Kedah, 6 Ogos 2019), 698.

94 Zakat fitrah adalah zakat yang perlu dilunaskan oleh semua umat Islam yang berkemampuan, pada bulan Ramadhan, untuk dirinya sendiri dan juga tanggungannya mengikut makanan asasi sesuatu tempat yang mengenyangkan

95 Mikail, \& Adekunle 'Sustainable Financial Inclusion: A Fiqh Analysis of Zakat,' (Kertas kerja, 1st Kedah International Zakat Conference, Lembaga Zakat Negeri Kedah, Kedah, 6 Ogos 2019), 709.

96 Abdullah, S., 'Zakat Harta Individu Berasaskan Nisab Emas: Kajian Syariah dan Perlaksanaannya di Selangor,' dalam Memperkasakan Kutipan dan Agihan Zakat di Malaysia, ed. Musa, Z. M., Ab Rahman, A., \& Abdul Wahab, A. (Nilai: Penerbit USIM, 2017), 217.

97 H. Rofie, A. Hamid, Dahaman, Hamid, \& A. Pozin, 'Tinjauan Awal Sorotan Karya Pengetahuan dan Pemahaman Peniaga Kecil Berkaitan Zakat Perniagaan,' (Kertas kerja, 1st Kedah International Zakat Conference, Lembaga Zakat Negeri Kedah, Kedah, 6 Ogos 2019), 1137.

98 Mohd. Ali, Hairunnizam, \& Nor Ghani, 'Kesedaran Membayar Zakat Pendapatan Kakitangan Professional: Kajian kes di UKM,' (Kertas kerja, Seminar Kebangsaan Dasar Awam dalam Era Globalisasi: Penilaian Semula Ke Arah Pemantapan Strategi, Bangi, Selangor, 16-17 September 2003). 


\section{Tujuan Berzakat}

Zakat pada asasnya ialah bertujuan untuk menyucikan harta yang diperolehi yang berkemungkinan dicemari dengan unsur-unsur yang dilarang oleh syarak ${ }^{99}$ kerana pemilikan harta tersebut mungkin melalui proses yang bercampur dengan hak-hak orang lain ${ }^{100}$ tanpa disedari oleh pemiliknya. Pengkaji lepas juga mendapati tujuan membayar zakat adalah untuk meningkatkan syiar Islam, ${ }^{101}$ contohnya pembayar zakat di Terengganu memberi mandat kepada kerajaan Terengganu untuk menggunakan dana zakat demi untuk memperkasakan undang-undang Syariah, meningkatkan pendidikan dan ekonomi Islam di negeri tersebut, merancakkan industri halal, membasmi kemiskinan dan mempercepatkan projek projek pembinaan agar dapat mencapai status kerajaan yang berlandaskan Syariah Islam sepenuhnya. ${ }^{102}$ Penyucian harta melalui zakat bukan sahaja mendidik si pemilik harta untuk tunduk patuh kepada perintah Allah tetapi juga sebagai salah satu cara untuk mencapai ketaqwaan. ${ }^{103}$

\section{Jenis-Jenis Harta yang Perlu Dizakatkan}

Harta yang diwajibkan zakat adalah harta yang mempunyai nilai, tahan lama, menguntungkan dan berpotensi untuk dikembangkan. ${ }^{104}$ Ini tidak termasuk

99 Ibrahim, 'Perbandingan Kaedah Kutipan Zakat Harta Harta oleh Institusi Zakat di Negeri-Negeri Utara Semenanjung Malaysia.' (Kertas kerja, 1st Kedah International Zakat Conference, Lembaga Zakat Negeri Kedah, Kedah, 6 Ogos 2019), 563.

100 Lahsasna, 'Wealth Purification, CIWM Special Edition 2013-2015, 20-22' https:// www.inceif.org/archive/wp-content/uploads/2018/02/Wealth-Purification.pdf, dicapai pada 1 Mei 2020.

101 Abdul Manap, 'Sustainable Food Security Through Zakat Fund in Malaysia,' (Kertas kerja, 1st Kedah International Zakat Conference, Lembaga Zakat Negeri Kedah, Kedah, 6 Ogos 2019), 729.

102 W. Hassan, Jamsari, Muslim, Alias, Zulkifli, \& Ahmad, 'The Dynamics of Zakat Distribution According to Shafii School of Law in Fatwas of Terengganu State,' International Journal of Civil Engineering and Technology, vol. 9/1 (2018): 771.

103 Qasim, 'The Role of Zakat in Poverty Alleviation in Nigerian Society' (Kertas kerja, 1st Kedah International Zakat Conference, Lembaga Zakat Negeri Kedah, Kedah, 6 Ogos 2019).

104 Rosele, M.I., 'Prinsip Al-Nama' dan Kedudukannya Zakat Semasa: Satu Tinjauan,' dalam Menelusuri Isu-Isu Kontemporari Zakat, ed. Md. Jani, R., Paizin, M. N., Abdullah, L., \& Rosele, M.I. (Kuala Lumpur: Pusat Pungutan Zakat, 2016), 2. 
harta seperti rumah, perabot, makanan dan pakaian untuk kegunaan sendiri. ${ }^{105}$ Di dalam al-Quran, telah dijelaskan beberapa jenis harta kekayaan yang perlu dizakatkan iaitu emas dan perak, ${ }^{106}$ tanaman, ${ }^{107}$ binatang ternakan, ${ }^{108}$ perdagangan $^{109}$ dan galian yang dikeluarkan dari perut bumi (rikaz dan ma'adin). ${ }^{110}$

Firman Allah SWT:

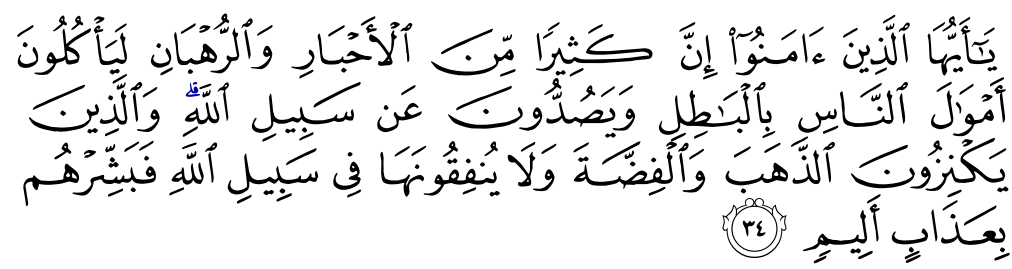

"Wahai orang-orang yang beriman! Sesungguhnya banyak di antara pendita-pendita dan ahli-ahli agama (Yahudi dan Nasrani) memakan harta orang ramai dengan cara yang salah, dan mereka menghalangi (manusia) dari jalan Allah (agama Islam). Dan (ingatlah) orang-orang yang menyimpan emas dan perak serta tidak membelanjakannya pada jalan Allah, maka khabarkanlah kepada mereka dengan (balasan) azab seksa yang tidak terperi sakitnya."

(Surah al-Tawbah, 9: 34)

Firman Allah SWT:

105 Rosele, M. I., Abdullah, L. \& Md. Ariffin, F., \& Isamail, M.Z., 'Konflik Hukum Zakat Pendapatan: Satu Penilaian,' Labuan e-Journal of Muamalat and Society, vol. 11 (2017): 13.

106 Senawi, \& Mat Isa, 'Analisis Emas sebagai Penanda Aras Nisab Zakat di Malaysia,' dalam Menelusuri Isu-Isu Kontemporari Zakat, ed. Md. Jani, R., Paizin, M. N., Abdullah, L., \& Rosele, M.I. (Kuala Lumpur: Pusat Pungutan Zakat, 2016), 203222.

107 Abdul Rahim, Ahmad Razimi, \& Ahmad, 'Zakat pertanian: Asas dan Perlaksanaan Semasa di Negeri Kedah Darulaman' (Kertas kerja, $1^{\text {st }}$ Kedah International Zakat Conference, Lembaga Zakat Negeri Kedah, Kedah, 6 Ogos 2019), 913.

108 Ahmad \& Wahid., 'Sumber Zakat: Perluasan Terhadap Harta yang Diikhtilaf,' Jurnal Syariah, vol. 13 (2005): 136.

109 Tajuddin, Shamsuddin, \& Mat Nor, 'Current Methods of Business Zakat Accounting in Malaysia.' (Paper presented at the $4^{\text {th }}$ International Conference on Management and Muamalah 2017, 7-8 November 2017), 586.

110 Thomson Reuters, Islamic Social Finance Report 2014 (Ontario, Canada: Thomson Reuters, 2014). 


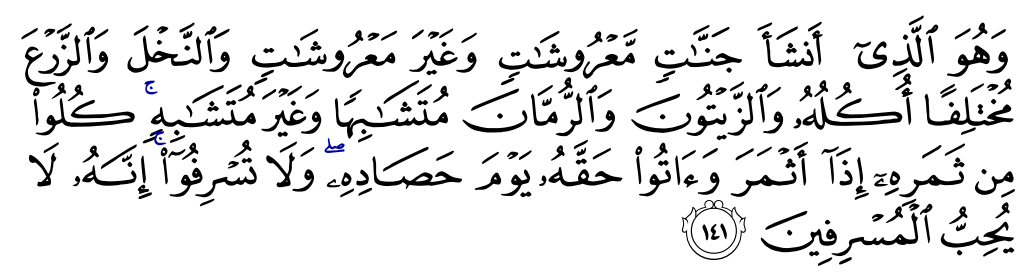

"Dan Dia lah (Allah) yang menjadikan (untuk kamu) kebunkebun yang menjalar tanamannya dan yang tidak menjalar; dan pohon-pohon tamar (kurma) dan tanaman-tanaman yang berlainan (bentuk, rupa dan) rasanya; dan buah zaiton dan delima, yang bersamaan (warnanya atau daunnya) dan tidak bersamaan (rasanya). Makanlah dari buahnya ketika ia berbuah, dan keluarkanlah haknya (zakatnya) pada hari memetik atau menuainya; dan janganlah kamu melampau (pada apa-apa jua yang kamu makan atau belanjakan); sesungguhnya Allah tidak suka kepada orang-orang yang melampau.'

(Surah al-An‘ām, 6: 141)

Firman Allah SWT:

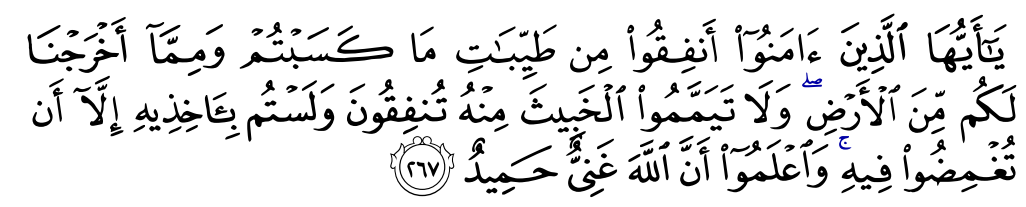

"Wahai orang-orang yang beriman! Belanjakanlah (pada jalan Allah) sebahagian dari hasil usaha kamu yang baikbaik, dan sebahagian dari apa yang Kami keluarkan dari bumi untuk kamu. Dan janganlah kamu sengaja memilih yang buruk daripadanya (lalu kamu dermakan atau kamu jadikan pemberian zakat), padahal kamu sendiri tidak sekali-kali akan mengambil yang buruk itu (kalau diberikan kepada kamu), kecuali dengan memejamkan mata padanya. Dan ketahuilah, sesungguhnya Allah Maha Kaya, lagi sentiasa Terpuji."

(Surah al-Baqarah, 2: 267) 


\section{Agihan Zakat kepada Lapan Kategori Asnaf}

Secara dasarnya, zakat perlu diagihkan kepada lapan kategori penerima yang telah ditentukan oleh syarak, bukan menurut logik atau emosi sendiri. ${ }^{111}$ Agihan zakat perlu didahulukan kepada asnaf fakir dan miskin. ${ }^{112}$ Menurut Lembaga Zakat Selangor, asnaf fakir bermaksud orang Islam yang harta atau pendapatannya tidak mencapai 50 peratus daripada had kifayah diri dan keluarganya sendiri. ${ }^{113}$ Manakala asnaf miskin itu bermaksud orang Islam yang harta atau pendapatannya melebihi 50 peratus bagi menanggung diri dan juga keluarganya, tetapi belum mencapai had kifayah. Kedua, zakat diagihkan kepada amil yang bertauliah atas lantikan pemerintah untuk mengutip dan menguruskan pengagihan zakat. ${ }^{114}$ Kategori asnaf ketiga yang layak menerima zakat ialah asnaf muallaf iaitu seseorang yang baru memeluk Islam ${ }^{115}$ atau yang hatinya cenderung dengan Islam walaupun masih lagi belum memeluk Islam. ${ }^{116}$

Golongan yang juga berhak menerima zakat keempat ialah asnaf riqab. Secara amnya, asnaf riqab ialah mereka yang berada di bawah cengkaman atau ditakluki oleh satu kekuasaan, pemerintahan atau pemikiran yang menyebabkan mereka tidak dapat menjalani kehidupan normal dan bebas seperti orang lain kerana mengalami gangguan mental dan emosi, kecelaruan

111 Eletrebi, Suleiman, \& Abdul Aziz, 'The Developmental Objectives (maqasid) of Zakah Institution in Kedah.' (Kertas kerja, 1st Kedah International Zakat Conference, Lembaga Zakat Negeri Kedah, Kedah, 6 Ogos 2019), 766.

112 Md Yusof, M. Tahir, \& Othman, 'Permasalahan golongan fakir dan miskin: Kajian dalam kalangan penerima bantuan zakat di Kedah.' (Kertas kerja, 1st Kedah International Zakat Conference, Lembaga Zakat Negeri Kedah, Kedah, 6 Ogos 2019), 595.

113 Lembaga Zakat Selangor, 'Penerimaan \& Kriteria Penerimaan Zakat' https://www.zakatselangor.com.my/agihan-zakat/penerimakriteria-penerimaan-zakat/, dicapai pada 1 Mei 2020.

114 Abd. Rahman, Abdullah, \& Ghazali, 'Wakalah Agihan Zakat Menerusi Perspektif Maqasid Syariah,' (Kertas kerja, $1^{\text {st }}$ Kedah International Zakat Conference, Lembaga Zakat Negeri Kedah, Kedah, 6 Ogos 2019), 858.

115 Md. Jaafar \& Osman, 'Pemerkasaan Agihan Zakat: Medium Pembangunan Resiliensi Asnaf Muallaf' (Kertas kerja, 1st Kedah International Zakat Conference, Lembaga Zakat Negeri Kedah, Kedah, 6 Ogos 2019), 464.

116 Ahmad-Zaluki \& Abdul Rahman, 'Kegunaan Wang Zakat untuk Pembangunan Asnaf Muallaf,' (Kertas kerja, 1st Kedah International Zakat Conference, Lembaga Zakat Negeri Kedah, Kedah, 6 Ogos 2019), 341. 
personaliti, kemiskinan serta pengangguran. ${ }^{117}$ Agihan zakat berikutnya ialah asnaf $f i$ sabilillah. Sabilillah itu merujuk kepada jalan yang menyampaikan ia kepada keredaan Allah SWT. ${ }^{118}$ Sebahagian ulama mentafsirkan asnaf $f i$ sabilillah terhad kepada berjihad mempertahankan agamaAllah SWT, manakala sebahagian lagi melonggarkan tafsiran $f i$ sabilillah itu kepada segala bentuk perbuatan yang dapat mendekatkan diri kepada Allah termasuk segala aktiviti kebajikan, kebaikan, ibadah haji dan umrah serta perjuangan dalam menuntut ilmu. ${ }^{119}$ Seterusnya ialah asnaf ghanimin iaitu orang Islam yang terpaksa berhutang untuk memenuhi keperluan asas dirinya dan tanggungannya. ${ }^{120}$ Ia juga boleh ditafsirkan sebagai seseorang yang berhutang untuk maslahat masyarakat tetapi ia tidak mampu melangsaikannya. Pengagihan zakat juga termasuk asnaf ibnu sabil iaitu orang Islam yang keputusan perbelanjaan kembaranya yang bertujuan mendapatkan keredaan Allah SWT.

Dari perspektif orang Islam yang beriman sebenar-benarnya kepada Allah SWT, mereka pasti mengikut suruhan Allah untuk memastikan dirinya membayar zakat mengikut ketetapan syarak dan sekiranya dirinya dalam posisi orang yang layak menerima zakat, sudah semestinya wang zakat yang diberikan itu digunakan dengan penuh berhemah, beramanah dan sentiasa menanamkan azam untuk keluar dari kepompong kemiskinan agar dapat menyertai golongan pembayar zakat pula. Tambahan pula, dana zakat sangat terhad dan agenda kelestarian zakat juga berkaitan dengan penyalurannya perlu diutamakan kepada mereka yang terlalu memerlukan sahaja. ${ }^{121}$

117 Ahmad, 'Agihan Zakat Merentasi Asnaf: Ke Arah Memperkasa Institusi Zakat,' (Kertas kerja, Persidangan Kebangsaan Ekonomi Malaysia, Kuantan, Pahang, 2-4 Jun 2009), 62.

118 Gadot, N., 'Konsep Asnaf Fisabilillah Mengikut Hukum Syarak,' (Kertas kerja, Seminar Pengagihan Zakat di bawah sinf Fisabillilah, Majlis Agama Islam Wilayah Persekutuan, Kuala Lumpur, 9 Jun 2009), 2.

119 Hassan \& M. Nasir., 'Prioritization of Zakat Distribution in Selangor and the Federal Territory of Malaysia: Are They Following the Right Distribution Principles according to Syariah?' Intellectual Discourse, Special Issue (2016): 435.

120 Ibrahim, \& Sahrim, 'Peranan Agihan Zakat sebagai Alat Kewangan Sosial Islam bagi Melangsaikan Hutang Golongan Al-Gharimin di Malaysia,' Labuan e-Journal of Muamalat and Society, vol. 13/1 (2019): 45.

121 Ahmad, Shukri, Ahmad, Kamarudin, Abd Hamid, Solahuddin, Dahaman, Mohd Akram \& Mohamad Cusairi, Rafidah, 'Kedudukan Orang Kurang Upaya (OKU) dalam Agenda Kelestarian Agihan Zakat Negeri Kedah,' (Kertas kerja, 1st Kedah International Zakat Conference, Lembaga Zakat Negeri Kedah, Kedah, 6 Ogos 2019), 330. 


\section{Pemahaman Mengenai Takaful}

Takaful adalah kata terbitan yang berasal dari kata kerja takafa, yatakafalu takafulan yang bermaksud saling menjamin, menjaga dan memelihara. ${ }^{122}$ Konsep ini merujuk kepada kelompok majoriti menjamin musibah kehilangan nyawa dan harta benda serta kesakitan atau kemalangan golongan minoriti dengan berkongsi tanggungjawab dan beban kesedihan kelompok minoriti tersebut melalui sumbangan daripada tabung yang dibangunkan bagi tujuan perkongsian risiko musibah ini. ${ }^{123}$ Ia diinspirasikan daripada seruan Islam yang menggalakkan orang beriman untuk beramal soleh melalui sumbangan wang dan hadiah terutamanya bagi meringankan bebanan kesedihan saudara-saudara seagama yang ditimpa musibah. ${ }^{124}$ Pengurusan kafala secara formal berbentuk keahlian di mana setiap anggota menyumbangkan sejumlah wang secara konsisten kepada tabung yang disediakan. Mana-mana anggota yang ditimpa musibah dibenarkan membuat tuntutan wang tersebut untuk digunakan oleh mangsa.

\section{Kewujudan Industri Takaful}

Kewujudan industri takaful bermula apabila kerajaan mendefinisikannya sebagai 'satu skim berasaskan persaudaraan, perpaduan dan bantu membantu bagi menyediakan bantuan kewangan bersama kepada anggota sekiranya benar-benar memerlukan di mana para anggota mempunyai persetujuan bersama untuk meyumbang bagi tujuan tersebut. ${ }^{125}$ Sejak itu, takaful menjadi salah satu instrumen kewangan Islam bagi membolehkan orang Islam bersama-sama melanggani insuran yang selama ini mempunyai unsur-unsur tidak patuh Syariah. Tiga puluh tahun kemudian Akta Takaful 1984 ini dimansuhkan dan industri Takaful diperkukuhkan dengan Akta Perkhidmatan Kewangan Islam 2013 (Akta 759) (APKI 2013) bagi memastikan operasi

122 Arif Fathillah Mohd Safar, 'Analisis Terhadap Elemen Maqasid Al-Syariah dalam Produk Takaful Ikhlas di Malaysia' (Disertasi Sarjana, Jabatan Fiqh and Usul, Akademi Pengajian Islam, Universiti Malaya, 2011), 83.

123 Alhabshi, \& S. Abdul Razak, 'Takaful Insurance: Concept, History and Development Challenges,' in The Foundations of Islamic Banking: Theory, Practice and Education, ed. Mohamed Ariff \& Munawar Iqbal (Cheltenham, Glasglow: Edward Elgar Publishing Limited., 2011), 184-207.

124 Mohd Fauzi, Abd Rashid, Sharkawi, Hasan, Aripin, Arifin, \& Muhammad, 'Takaful: A review on performance, issues and challenges in Malaysia,' Journal of Scientific Research and Development, vol. 3/4 (2016): 71.

125 Seksyen 2, Akta Takaful 1984. 
takaful dapat diselaraskan dengan instrumen kewangan Islam yang lain agar aspek pematuhan Syariah dapat dimantapkan. ${ }^{126}$

\section{Tujuan Melanggani Takaful}

Pakar kewangan peribadi menyarankan orang awam terutamanya penyumbang nafkah terbesar di dalam keluarga agar melanggani takaful bagi meminimumkan risiko akibat ditimpa musibah kematiannya, kehilangan upaya sementara atau kekal, kecacatan, dihinggapi penyakit kronik dan kehilangan harta benda. ${ }^{127}$ Ini disebabkan takaful adalah pengurusan risiko yang paling efektif buat masa ini bagi memastikan tanggungan tidak dibebani dengan hutang atau terpaksa meminta-minta kerana sudah kehilangan sumber kewangan. ${ }^{128}$ Sementara itu, ibu bapa juga disarankan melanggani takaful pendidikan seawal usia anak-anak 15 hari sebagai tabung simpanan untuk digunakan anak-anak bagi membiayai kos pengajian yang semakin hari, semakin tinggi. ${ }^{129}$ Pelan pendidikan anak-anak sangat membantu kerana anak-anak nanti tidak terlalu bergantung dengan pinjaman pendidikan pengajian. ${ }^{130}$ Dengan cara ini, anakanak akan lebih berkeyakinan untuk memulakan pekerjaan tanpa diserabuti dengan masalah membayar balik pinjaman pendidikan. ${ }^{131}$ Pengambilan takaful perumahan juga dilihat sebagai satu kewajipan apabila individu itu membiayai

126 Abd. Hamid, \& Hassan, 'Akta Perkhidmatan Kewangan Islam 2013: Tinjauan Awal Kesannya dalam Industri Takaful,' Kanun: Jurnal Undang-Undang Malaysia, vol. 26/2 (2014): 254.

127 Perbadanan Insurans Deposit Malaysia, 'Perlindungan bagi Sistem Perlindungan Manfaat Takaful dan Insurans,' https://www.pidm.gov.my/ms-my/for-public/ takaful-and-insurance-benefits-protection-system/coverage-for-tips/, dicapai pada 1 Mei 2020.

128 W. Deraman, \& Ab. Rahaman, 'Takaful Urus Risiko Ikut Prinsip Syariah,' BHOnline, https://www.bharian.com.my/rencana/agama/2019/03/544195/takafulurus-risiko-ikut-prinsip-syariah, dicapai pada 1 Mei 2020.

129 Asri, 'Budaya Menabung Rakyat Malaysia Masih Rendah,' https://www.bharian. com.my/berita/nasional/2018/09/479153/budaya-menabung-rakyat-malaysiamasih-rendah, dicapai pada 1 Mei 2020.

130 Nasihat kewangan, "4 langkah mudah untuk mencipta dana pendidikan anakanak tanpa melibatkan pinjaman,' https://www.nasihatkewangan.com/2020/03/4langkah-mudah-untuk-mencipta-dana.html, dicapai pada 1 Mei 2020.

131 Azmi, 'PTPTN tawar simpanan RM500 percuma RM500 untuk 500,000 pelajar,' https://www.bharian.com.my/bisnes/korporat/2018/05/422625/ptptn-tawarsimpanan-rm500-percuma-rm500-untuk-500000-pelajar, diterbitkan pada $15 \mathrm{Mei}$ 2018, dicapai pada 1 Mei 2020. 
kediaman dengan pinjaman perumahan kerana sekiranya musibah kematian berlaku, waris yang ditinggalkan tidak perlu risau untuk melangsaikan hutang pinjaman tersebut. ${ }^{132}$

\section{Jenis-Jenis Takaful}

Secara amnya, produk takaful terbahagi kepada dua iaitu takaful keluarga dan takaful am. Pelan takaful keluarga terbahagi kepada lima pelan utama iaitu pelan keluarga, pelan berkaitan pelaburan, pelan pendidikan anak, pelan perubatan dan kesihatan dan pelan anuiti. Pelan anuiti ialah berkaitan dengan anuiti persaraan bagi memastikan pencarum KWSP mendapat perlindungan dari risiko kehabisan sumber kewangan sepanjang hayat persaraan. Manakala pelan takaful am terdiri daripada pelan rumah, pelan motor dan pelan kemalangan diri. Pelan rumah terdiri kepada dua bahagian iaitu perlindungan ke atas rumah sekiranya terjadinya gempa bumi atau banjir besar yang mengakibatkan kerosakan kepada rumah kediaman. Kedua pelan isi rumah iaitu perlindungan terhadap empunya rumah sekiranya berlaku kematian. ${ }^{133}$

\section{Pemahaman Mengenai Pinjaman Kewangan}

Pinjaman kewangan adalah satu kemudahan daripada institusi kewangan untuk membolehkan orang ramai berhutang. Dalam konteks Malaysia, institusi kewangan yang menawarkan perkhidmatan kewangan bagi orang awam untuk berhutang ialah bank perdagangan. ${ }^{134}$ Bagi orang awam yang ingin berhutang bagi tujuan pembelian rumah kediaman, mereka perlu memastikan institusi kewangan itu berlesen di bawah Kementerian Perumahan dan Kerajaan Tempatan. Pemahaman kewangan mengenai pinjaman boleh dikatakan tinggi sekiranya seseorang itu memastikan institusi kewangan itu berlesen, mengkaji kadar faedah dan tujuan pembiayaan. Bagi seorang individu Muslim, ia bukan sahaja perlu memastikan pinjaman kewangan itu bebas daripada unsur riba,

132 Jomurusduit.com., 'Bila perlu ambil perlindungan Insurans/Takaful,' https:// jomurusduit.com/2016/08/bila-perlu-ambil-perlindungan-insurans-takaful.html, dicapai pada 1 Mei 2020.

133 Hazly Takaful, 'Memahami apa itu insurans dan takaful?' https://hazlytakafulge. wordpress.com/2014/02/16/memahami-apa-itu-insurans-dan-takaful/, dicapai pada 1 Mei 2020.

134 AKPK, 'Jenis-jenis pinjaman.' https://www.akpk.org.my/content/482-jenis-jenispinjaman., dicapai pada 1 Mei 2020. 
maysir dan gharar, tetapi menjadi kewajipannya untuk memastikan tujuannya untuk berhutang itu berlandaskan syarak. ${ }^{135}$

\section{Perbezaan di Antara Pinjaman Konvensional dan Pinjaman Patuh Syariah}

Perbezaan utama antara pinjaman konvensional dan pinjaman dari institusi kewangan Islam ialah riba. Firman Allah SWT:

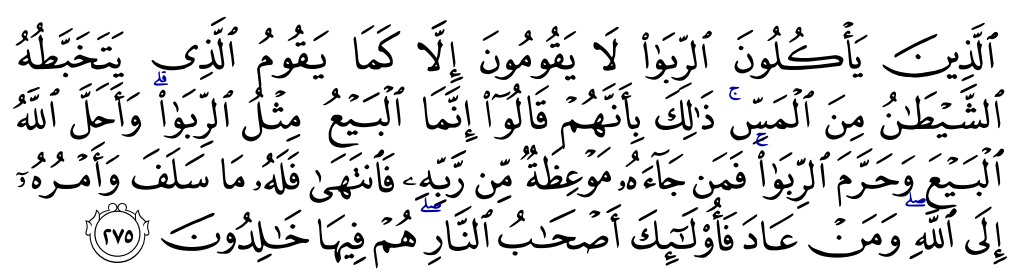

"Orang-orang yang memakan (mengambil) riba itu tidak dapat berdiri betul melainkan seperti berdirinya orang yang dirasuk Syaitan dengan terhuyung-hayang kerana sentuhan (Syaitan) itu. Yang demikian ialah disebabkan mereka mengatakan: "Bahawa sesungguhnya berniaga itu sama sahaja seperti riba". Padahal Allah telah menghalalkan berjual-beli (berniaga) dan mengharamkan riba. Oleh itu sesiapa yang telah sampai kepadanya peringatan (larangan) dari Tuhannya lalu ia berhenti (dari mengambil riba), maka apa yang telah diambilnya dahulu (sebelum pengharaman itu) adalah menjadi haknya, dan perkaranya terserahlah kepada Allah. Dan sesiapa yang mengulangi lagi (perbuatan mengambil riba itu) maka itulah ahli neraka, mereka kekal di dalamnya."

(Surah al-Baqarah, 2: 275)

Pinjaman konvensional tiada peruntukan untuk mematuhi prinsip-prinsip Syariah kerana semua produknya berasaskan keuntungan apabila faedah akan dikenakan ke atas jumlah pinjaman yang diberikan kepada peminjam. ${ }^{136}$ Pinjaman patuh Syariah yang dijalankan oleh institusi kewangan Islam berdasarkan faktor tuntutan agama agar segala transaksi perlu bebas dari unsur

135 Bank Muamalat, 'Perbandingan antara perbankan Islam dan konvensional,' https://www.muamalat.com.my/downloads/media-room/publications/PerbankanISLAM-\&-Konvensional-web.pdf, dicapai pada 1 Mei 2020.

136 Bankinginfo.com, 'Apakah perbankan Islam?' http://www1.bankinginfo.com. my/_system/media/downloadables/perbankan_islam.pdf, dicapai pada 1 Mei 2020 . 
riba, ${ }^{137}$ maysir, ${ }^{138}$ gharar $^{139}$ dan penipuan. Pinjaman konvensional dibezakan dengan terminologi pembiayaan dalam perbankan Islam. Berbeza dengan pinjaman konvensional, keuntungan daripada pembiayaan adalah terhasil daripada jualan aset berdasarkan kontrak tawarruq ${ }^{140}$ atau bay ' al- 'inah. ${ }^{141}$

\section{Tujuan Meminjam Wang dari Institusi Kewangan}

Sorotan kajian lepas mendapati tiga tujuan utama individu perlu membuat pinjaman dengan institusi kewangan. Pertama, untuk pembelian rumah kediaman, ${ }^{142}$ kedua perjanjian sewa beli kenderaan memerlukan seseorang untuk membuat pinjaman ${ }^{143}$ dan yang ketiga adalah untuk penyatuan hutanghutang yang sedia ada. ${ }^{14}$ Contohnya, apabila seseorang itu mempunyai hutang dua kad kredit yang belum dilunaskan faedahnya sebanyak 18\% setahun, mereka menggabungkan kedua dua hutang dari kad kredit tersebut dan membayarnya sekali gus dengan menggunakan pinjaman peribadi yang faedahnya lebih rendah daripada kadar faedah kad kredit. ${ }^{145}$

\footnotetext{
137 Merujuk kepada riba al-nasì'ah iaitu faedah yang dikenakan ke atas pinjaman.

138 Sebarang transaksi kewangan yang memperoleh keuntungan melalui nasib semata mata, spekulasi atau andaian.

139 Sebarang transaksi kewangan yang kewujudan atau deskripsinya tidak jelas.

140 Merujuk kepada transaksi jual beli komoditi atau aset berasaskan pembayaran tangguh secara murābahah (iaitu harga kos aset ditambah dengan margin keuntungan) atau musāwamah (jual beli yang tidak mendedahkan harga kos aset dan margin keuntungan) daripada penjual kepada pembeli, dan kemudiannya komoditi atau aset tersebut akan dijual secara tunai kepada pihak ketiga (selain daripada penjual asal) bagi mendapatkan tunai.

141 Pembiayaan yang melibatkan akad jual beli yang disusuli dengan pembelian semula oleh penjual pada harga yang berbeza.

142 DirectLending.com.my, 'Mengapa kita membuat pinjaman?' http://www. insuranceinfo.com.my/learn_the_basics/types_of_takaful.php?intPrefLangID=2, dicapai pada 1 Mei 2020.

143 Peminjam dalam pinjaman sewa beli dikenali sebagai penyewa dan institusi kewangan pula ialah pemilik kenderaan tersebut. Hak milik kenderaan itu akan berpindah kepada penyewa selepas semua ansuran dijelaskan.

144 CompareHero.my., 'Compare Debt Consolidation Personal Loans,' https://www. comparehero.my/personal-loan/debt-consolidation, dicapai pada 1 Mei 2020.

145 Ringgitplus.com., 'Best Personal Loans in Malaysia 2020.'
} 


\section{METODOLOGI KAJIAN}

\section{Pembolehubah Bersandar}

Pembolehubah bersandar untuk kajian ini adalah Pemahaman Kewangan Islam yang terdiri daripada tiga element utama iaitu zakat, takaful dan juga pinjaman. Soalan-soalan ini telah melalui proses pengesahan daripada pakarpakar sebelum kajian rintis dijalankan ke atas mahasiswa pengajian Islam. Soalan-soalan ini hanya tertumpu kepada kewangan Islam dan tidak tertumpu kepada soalan-soalan yang kebiasaannya didapatkan oleh sarjana kewangan di peringkat global seperti OECD dan CFPB.

Memandangkan mahasiswa tidak mempunyai pendapatan tetap seperti mereka yang sudah bekerja, maka soalan zakat hanya berkisar kepada pengetahuan mengenai pengagihan zakat, sejajar dengan latarbelakang mereka yang melihat zakat sebagai dana kewangan bagi membiayai pendidikan mereka. Soalan senario mengenai takaful tidak diberatkan dengan soalan teknikal seperti menguji pemahaman mereka mengenai kontrak takaful atau jenis-jenis produk takaful kerana kebanyakan mahasiswa masih tiada pendedahan dalam melanggani produk takaful. Jadi, soalan sengaja diolah untuk menguji sikap mereka terhadap takaful berdasarkan pemahaman mereka. Manakala, soalan senario sengaja dibina untuk melihat cara mereka membuat keputusan kewangan apabila terdesak untuk membiayai pendidikan mereka dengan pinjaman yang berasaskan riba. Soalan senario mengenai pinjaman ini merupakan soalan aplikasi kewangan yang seharusnya setiap mereka perlu faham bahawa riba adalah perkara yang dilarang oleh agama. Jenis soalan senario yang terakhir hanyalah soalan tambahan untuk melihat kecenderungan mahasiswa tentang seruan berhemah ketika berbelanja. ${ }^{146}$

\section{Ujian Pengesahan Kandungan (Content Validity)}

Memandangkan soalan ini adalah soalan senario yang dibina sendiri oleh pengkaji, maka keempat-empatnya telah melalui ujian pengesahan kandungannya (content validity) dengan pakar yang terpilih sebelumnya. ${ }^{147}$ Dua belas soalan telah dibentangkan kepada tujuh pakar yang mahir dalam bidang

146 Diadaptasi daripada kajian Abdullah \& Anderson, 'Islamic Financial Literacy among Bankers in Kuala Lumpur,' 8.

147 Diadaptasi daripada Armstrong, Marlene, Cohen, Eriksen, \& Cleeland, 'Content Validity of Self-Report Measurement Instrument Instruments: An Illustration from the Development of the Brain Tumor Module of the M.D. Anderson Symptom Inventrory,' Oncology Nursing, vol. 32/3 (2005): 672-673. 
pengurusan harta (wealth management) terutamanya zakat dan takaful. Pakar pakar ini diminta untuk mengesahkan isi kandungan soalan yang diberikan berdasarkan empat karakteristik iaitu 1) kesesuaian soalan untuk diuji ke atas mahasiswa, 2) ukuran keterwakilan sama ada sampel mahasiswa yang dipilih sesuai untuk mewakili populasi mahasiswa jurusan Islam atau tidak, 3) consistency iaitu mengukur sama ada soalan yang disenaraikan mampu membuatkan konsep yang disebut dalam sorotan kajian lepas beroperasi, 4) kejelasan iaitu mengukur sama ada soalan yang dibentangkan itu mampu difahami dengan jelas oleh mahasiswa. Setiap pakar diberi peluang untuk menilai soalan-soalan yang diberikan melalui 4-point Likert scale iaitu $1=$ tidak sesuai langsung, 2 = tidak sesuai $3=$ sesuai and $4=$ sangat sesuai. Setiap soalan mempunyai markah penuh iaitu 28 markah (4 karakteristik x 7 pakar). Jumlah skor akan mengumpulkan keseluruhan markah yang diberikan oleh pakar-pakar dan menjadikan skor keseluruhan menjadi 112 markah. Hanya soalan yang skor 90 markah dan ke atas sahaja yang akan diambil dan diuji ke atas para mahasiswa untuk tinjauan rintis. Hanya empat soalan sahaja yang dapat skor tinggi oleh pakar-pakar tersebut. 
Jurnal Syariah, Jil. 28, Bil. 2 (2020) 189-262

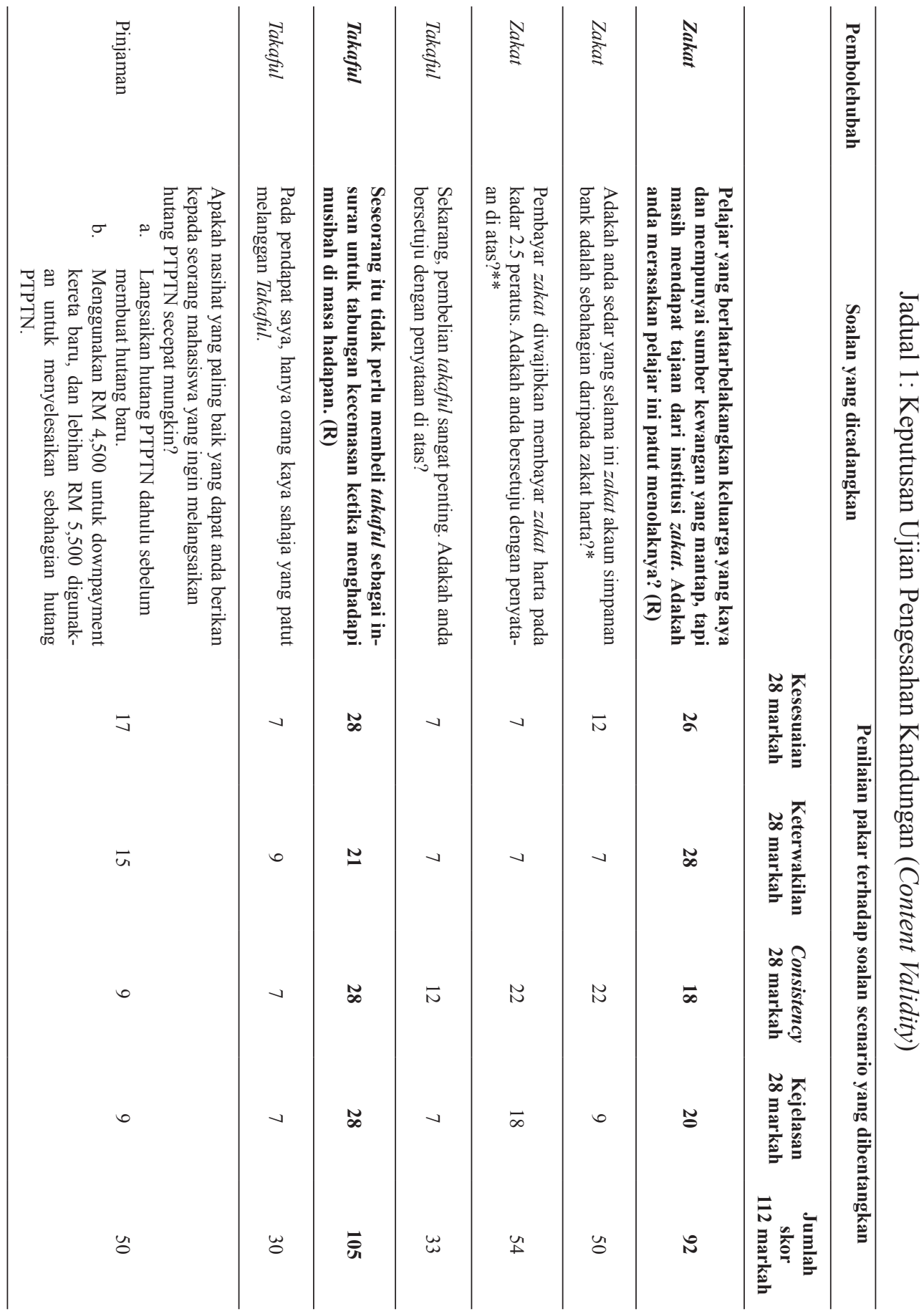


Analisis Pemahaman Kewangan dalam Kalangan Mahasiswa Akademi Pengajian Islam Universiti Malaya

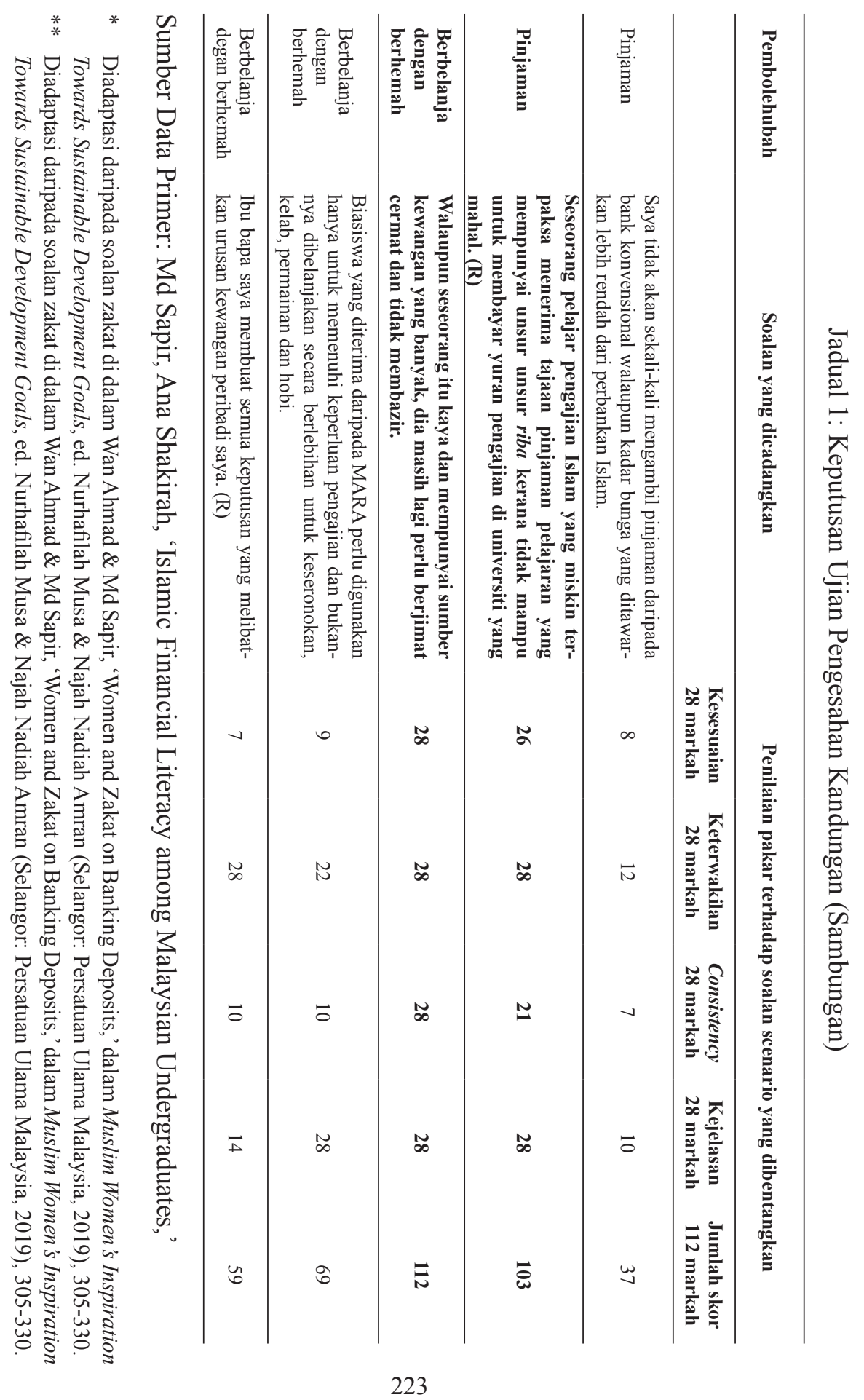


Manakala pembolehubah tidak bersandar ialah profil demografik mahasiswa. Sepuluh soalan demografik dimuatkan di dalam soal kaji selidik, tetapi untuk artikel ini, pengkaji memutuskan untuk menumpukan kepada empat demografik utama iaitu jurusan pengajian, sumber kewangan mahasiswa, jenis pinjaman yang dipohon untuk membiayai pendidikan dan cara mereka membelanjakan wang. Keempat-empat demografik ini telah diperbincangkan dengan jelas sebelum ini. Pakar-pakar kewangan bersetuju menyatakan bahawa menggunakan pelan pendidikan yang ditawarkan oleh takaful adalah usaha yang paling efektif bagi membiayai kos pengajian tinggi anak-anak.

Jadual 2: Jurusan Pengajian Islam

\begin{tabular}{ll}
\hline \multicolumn{1}{c}{ Pembolehubah } & \multicolumn{1}{c}{ Rujukan } \\
\hline Syariah* & Akademi Pengajian Islam, Universiti \\
Usuluddin** & Malaya \\
Pengajian \& Pendidikan Islam & \\
\hline
\end{tabular}

Sumber Data Primer: Md Sapir, Ana Shakirah, 'Islamic Financial Literacy among Malaysian Undergraduates.'

* Jurusan Syariah di Akademi Pengajian Islam terdiri daripada Pengurusan Muamalat, Undang-undang, Fiqh Usul, Ekonomi, Sains Politik Islam dan Astronomi.

** Jurusan Usuluddin di Akademi Pengajian Islam terdiri daripada Akidah dan Pemikiran Islam, Al-Quran dan Hadis, Dakwah dan Sejarah Tamadun.

Jadual 3: Sumber Kewangan Pembelajaran

\begin{tabular}{ll}
\hline \multicolumn{1}{c}{ Pembolehubah } & \multicolumn{1}{c}{ Rujukan } \\
\hline Menggunakan wang persendirian & Md.Sapir @ Md.Shafik, A. and Wan Ahmad, \\
& W. (2020), 'Financial literacy among Malaysian \\
& Muslim undergraduates', Journal of Islamic \\
& Accounting and Business Research \\
Ibu Bapa menampung keseluruhan & Education planner.org (2011). Why save for your \\
pembelajaran & child's future? \\
& KWSP (2020). Finance your higher education: \\
& Pursue a brighter future for you or your children. \\
& Infopelajar2u. Derma siswa melanjutkan \\
pelajaran ke IPT tempatan Zakat Kedah.
\end{tabular}


Menggunakan pelan Pendidikan

Mendapat pinjaman Pendidikan
Education planner.org (2011). Why save for your child's future?

Mahalingam (2012). Saving and investing for a child's education is imperative with ever-rising cost.

Thilinadan (2019). Culas bayar PTPTN khianati pelajar $B 40$.

Sumber Data Primer: Md Sapir, Ana Shakirah, 'Islamic Financial Literacy among Malaysian Undergraduates.'

Jadual 4: Jenis pinjaman untuk membiayai pembelajaran

\begin{tabular}{ll}
\hline \multicolumn{1}{c}{ Pembolehubah } & \multicolumn{1}{c}{ Rujukan } \\
\hline Perbadanan Tabung Pendidikan Tinggi & Patho Rohman (2019). Amalan terdahulu punca \\
Nasional (PTPTN) & PTPTN berhutang RM 40 billion. \\
Pinjaman Bank & Ringgitplus.com. Best Personal Loans in \\
& Malaysia 2020. \\
Pinjaman dari kaum kerabat & Md Sapir, Ana Shakirah (2016). Islamic \\
& Financial Literacy among Malaysian \\
& Undergraduates. \\
\hline
\end{tabular}

Sumber Data Primer: Md Sapir, Ana Shakirah, 'Islamic Financial Literacy among Malaysian Undergraduates.'

Jadual 5: Cara membelanjakan sumber kewangan pendidikan

\begin{tabular}{ll}
\hline \multicolumn{1}{c}{ Pembolehubah } & \multicolumn{1}{c}{ Rujukan } \\
\hline Yuran pengajian & $\begin{array}{l}\text { College Choice (2020). What are the major } \\
\text { expenses for students. }\end{array}$ \\
Kos Sara Hidup & $\begin{array}{l}\text { Caldwell (2019). Choosing between On and Off } \\
\text { Campus Living Options. }\end{array}$ \\
Hiburan & $\begin{array}{l}\text { FinAid. (2016). Defining education }- \text { related } \\
\text { expenses. }\end{array}$
\end{tabular}

Sumber Data Primer: Md Sapir, Ana Shakirah, 'Islamic Financial Literacy among Malaysian Undergraduates.'

\section{DATA MENGENAI RESPONDEN}

Kajian telah memilih responden yang terdiri daripada mahasiswa Islam di Akademi Pengajian Islam, Universiti Malaya (APIUM). Walaupun APIUM mempunyai cawangan di Nilam Puri, Kelantan, tetapi kajian ini 
hanya menggunakan sampel dari kampus utamanya di Bangsar, Kuala Lumpur. Pemilihan mahasiswa Islam dari kampus ini berdasarkan kriteria dan latarbelakang mereka amat bertepatan untuk melambangkan karakter mahasiswa yang mengikuti pengajian dalam jurusan yang berunsurkan keislaman, dan pada masa yang sama mereka terlihat canggih kerana terdedah kepada suasana persekitaran kampus yang bertransaksi tanpa tunai, mengikuti pengajian menggunakan kaedah e-learning serta menggunakan kemudahan seperti sistem pengangkutan awam yang moden. Ketika kajian ini dijalankan sepanjang Oktober 2016, terdapat kira kira 1,205 mahasiswa yang mengikuti pengajian Ijazah Dasar di APIUM. ${ }^{148}$ Jadi, kami mengagihkan 300 soal selidik kepada mahasiswa ini pada 4 Oktober-6 Oktober 2016. Sebanyak 294 dapat dikutip semula, dan hanya 224 soal selidik yang dapat digunakan untuk dianalisa. Jadual 6 di bawah adalah jumlah responden berdasarkan jurusan yang mereka daftar di APIUM bagi Sesi 2016 / 2017. Kajian ini menggunakan SPSS 23.0 yang kemudiannya dinaiktaraf kepada SPSS 25.0 untuk menganalisa statistik deskriptif.

\section{ANALISA KAJIAN DESKRIPTIF}

Analisa kajian diadaptasi daripada pengkaji yang terkenal dalam bidang kewangan literasi. ${ }^{149}$ Analisa deskriptif amat perlu bagi memahami latar belakang responden, seterusnya dapat mengenal pasti cara mereka memahami pengurusan kewangan.

Jadual 6: Responden mengikut jurusan pengajian pada sesi 2016 / 2017

\begin{tabular}{lcc}
\hline \multicolumn{1}{c}{ Jurusan } & $\begin{array}{c}\text { Jumlah responden } \\
(\mathbf{N = 2 2 4 )}\end{array}$ & Peratusan (\%) \\
\hline Syariah* & 86 & $38 \%$ \\
Usuluddin** & 78 & $35 \%$ \\
Pengajian \& Pendidikan Islam & 60 & $27 \%$ \\
\hline
\end{tabular}

Sumber Data Primer: Md Sapir, Ana Shakirah, 'Islamic Financial Literacy among Malaysian Undergraduates.'

* Jurusan Syariah di Akademi Pengajian Islam terdiri daripada Pengurusan Muamalat, Undang-undang, Fiqh Usul, Ekonomi, Sains Politik Islam dan Astronomi.

** Jurusan Usuluddin di Akademi Pengajian Islam terdiri daripada Akidah dan Pemikiran Islam, Al-Quran dan Hadis, Dakwah dan Sejarah Tamadun.

148 Berdasarkan pertanyaan pengkaji kepada kakitangan Pejabat Ijazah Dasar, Akademi Pengajian Islam pada 4 Oktober 2016, tentang jumlah pelajar Ijazah Dasar yang mendaftar bagi sesi 2016/2017.

149 Adele Atkinson and Flore-Anne Messy, Measuring Financial Literacy, 5. 
Berdasarkan data dalam Jadual 6, jumlah pelajar Usuluddin dan Pengajian $\&$ Pendidikan Islam mendominasi kajian ini dengan peratusan $62 \%$, manakala responden yang mengambil Syariah ialah sebanyak 38\%. Jadi analisa menggunakan silang tabulasi antara jurusan dan pemahaman kewangan dijangka bakal memberi banyak input baru kepada pihak pentadbir Universiti untuk merangka pendidikan kewangan yang berbeza di antara pelajar Syariah dan Non-Syariah.

Jadual 7: Responden mengikut sumber kewangan pembelajaran

\begin{tabular}{lcc}
\hline \multicolumn{1}{c}{ Sumber kewangan pembelajaran } & $\begin{array}{c}\text { Jumlah } \\
\text { responden } \\
(\mathbf{N = 2 2 4 )}\end{array}$ & Peratusan (\%) \\
\hline Menggunakan wang persendirian & 62 & $27.6 \%$ \\
Ibu Bapa menampung keseluruhan pembelajaran & 22 & $9.8 \%$ \\
Mendapat tajaan biasiswa & 41 & $18.3 \%$ \\
Menggunakan pelan Pendidikan & 3 & $1.4 \%$ \\
Mendapat pinjaman Pendidikan & 96 & $42.9 \%$ \\
\hline
\end{tabular}

Sumber Data Primer: Md Sapir, Ana Shakirah, 'Islamic Financial Literacy among Malaysian Undergraduates.'

Jadual 7 menunjukkan dapatan kajian mengenai sumber kewangan pembelajaran responden. Didapati ramai responden mendapat sumber kewangan melalui pinjaman pendidikan (42.9\%). Ia agak membimbangkan kerana mahasiswa terpaksa mengambil pinjaman seawal usia muda dan ia kelihatan bakal membebankan mereka dengan tuntutan pembayaran pinjaman dalam tempoh jangka masa panjang selepas tamat pengajian. Corak pinjaman pendidikan di atas juga mengambarkan bahawa melanggan pelan pendidikan sejak seawal kelahiran mahasiswa ini tidak mendapat sambutan dalam kalangan ibu bapa mahasiswa Islam ini, sedangkan pengambilan pelan Pendidikan oleh ibu bapa adalah salah satu bentuk usaha yang dikenal pasti efektif untuk membiayai pengajian tinggi anak anak tanpa perlu meminjam atau bergantung kepada bantuan kewangan yang lain. ${ }^{150}$ Keadaan yang membimbangkan ini membuatkan pengkaji mengambil inisiatif mengkaji dengan lebih lanjut tentang jenis-jenis pinjaman yang dibuat oleh mahasiswa ini bagi mengetahui

$\overline{150}$ Mohd Khairil Ashraf \& Wan Mohd Saipuddin, 'Bijak Mengurus Wang,' (Seminar organized by University Malaya Muslim Undergraduate Students Association at BS1, Academic of Islamic Studies, University Malaya, Kuala Lumpur, 30 November 2016). 
sama ada responden memilih pinjaman yang bebas daripada unsur riba atau tidak, dan ia seperti yang dinyatakan dalam Jadual 8.

Jadual 8: Responden mengikut jenis pinjaman

\begin{tabular}{lcc}
\hline \multicolumn{1}{c}{ Jenis-jenis pinjaman } & $\begin{array}{c}\text { Jumlah } \\
\text { responden } \\
(\mathbf{N = 9 6 )}\end{array}$ & $\begin{array}{c}\text { Peratusan } \\
\mathbf{( \% )}\end{array}$ \\
\hline $\begin{array}{l}\text { Perbadanan Tabung Pendidikan Tinggi Nasional } \\
\text { PTPTN) }\end{array}$ & 91 & $94.8 \%$ \\
Pinjaman Bank & 3 & $3.1 \%$ \\
Pinjaman dari kaum kerabat & 2 & $2.1 \%$ \\
\hline
\end{tabular}

Sumber Data Primer: Md Sapir, Ana Shakirah, 'Islamic Financial Literacy among Malaysian Undergraduates'

Jadual 8 menunjukkan hasil kajian mengenai jenis-jenis pinjaman yang telah dibuat oleh responden bagi membiayai kos pengajian di Universiti Malaya. Didapati bahawa hampir keseluruhan mereka mendapatkan pinjaman PTPTN (94.8\%), jadi mereka tidak terdedah kepada pinjaman berunsurkan riba kerana PTPTN telah diputuskan oleh Jawatankuasa Fatwa Kebangsaan sebagai patuh Syarak. ${ }^{151}$ Seterusnya Jadual 9 menunjukkan bagaimana responden membelanjakan wang dari sumber ini.

Jadual 9: Responden mengikut cara membelanjakan sumber kewangan pendidikan

\begin{tabular}{ccc}
\hline Sumber kewangan pembelajaran & $\begin{array}{c}\text { Jumlah } \\
\text { responden } \\
\text { (N=224) }\end{array}$ & $\begin{array}{c}\text { Peratusan } \\
(\mathbf{\%})\end{array}$ \\
\hline Yuran pengajian & 189 & $84.4 \%$ \\
Kos Sara Hidup & 32 & $14.0 \%$ \\
Hiburan* & 3 & $1.6 \%$ \\
\hline
\end{tabular}

Sumber Data Primer: Md Sapir, Ana Shakirah, 'Islamic Financial Literacy among Malaysian Undergraduates.'

* Pengkaji mengkategorikan pelan data prabayar setiap bulan sebagai hiburan, tetapi ramai mahasiswa berpendapat pelan data ini adalah termasuk sebagai kos sara hidup.

151 Perbadanan Tabung Pendidikan Tinggi Nasional (PTPTN), 'Pembiayaan PTPTN bukan Riba', https://www.ptptn.gov.my/images/fail/siaran_media/2016/sm_ pembiayaan_ptptn_bkn_riba.pdf, dicapai pada 23 September 2019. 
Jadual 9 mendapati sumber kewangan pendidikan responden banyak dihabiskan untuk membayar yuran pengajian sahaja (84.4\%). Kebanyakan mahasiswa menetap di dalam kolej kediaman, dan hanya sebilangan dari pelajar Ijazah Dasar yang terpaksa menyewa di luar kampus. Jadi, bagi pelajar yang menyewa di luar kampus terpaksa juga untuk membahagikan sumber kewangan yang diterima di antara yuran pengajian dan kos sara hidup (14.0\%). Ini berkemungkinan di antara sebab mengapa kebanyakan mahasiswa di Universiti Malaya terpaksa mencari kerja secara separuh masa bagi menampung kos sara hidup yang tidak mencukupi. ${ }^{152}$

\section{ANALISA MENGGUNAKAN SILANG TABULASI}

Analisa menggunakan silang tabulasi ${ }^{153}$ banyak digunakan di dalam kajian pemasaran untuk mendapatkan trend ${ }^{154}$ atau patterns ${ }^{155}$ pembelian sesuatu barang. Bagaimana pun, beberapa pengkaji kewangan telah menggunakan kaedah iniuntuk mengkaji gelagat dan tabiat pengurusan kewangan seseorang. ${ }^{156}$ Analisa menggunakan teknik amat sesuai untuk digunakan dalam kajian ini kerana ia melibatkan categorical data ${ }^{157}$ yang dapat membantu pengkaji untuk meneroka cara mahasiswa Islam memahami kewangan Islam. Di dalam artikel ini, keputusan silang tabulasi di antara demografik mahasiswa dan soalan zakat dipersembahan di dalam Jadual 10 sehingga Jadual 13. Manakala demografik mahasiswa dan soalan zakat berada di dalam Jadual 14 sehingga

$\overline{152}$ Ana Shakirah Md Sapir, 'Islamic Financial Literacy among Malaysian Undergraduates', 101-102.

153 Satu kaedah untuk menganalisa hubungan di antara beberapa pembolehubah.

154 Segala sesuatu yang sedang dibicarakan, digemari atau digunakan oleh sebahagian besar masyarakat pada masa tertentu. Lihat Trend Remaja, 'Definisi atau Pengertian Trend' https://remajanew.blogspot.com/2015/01/Definisi-pengertiantrend.html, dicapai pada 1 Mei 2020.

155 Corak atau bentuk analisis teknikal adalah agregat keadaan pasaran tertentu dan menentukan tindakan pedagang. Terdapat dua jenis corak: berterusan (menunjukkan kewujudan pembetulan interim trend) dan terbalik (peralihan dari trend semasa). Semua corak berulang dalam graf pada satu masa disebabkan kitaran pasaran. Corak adalah salah satu teknik analisis utama pedagang kerana universal untuk pasaran kewangan dan rangka masa yang berbeza. Lihat Alpari, 'Pattern' https://alpari.com/ms/beginner/glossary/pattern/, dicapai pada 1 Mei 2020.

156 Chen \& Volpe (1998) dan Lusardi, S. Mitchell \& Curlo (2010) antara pengkaji kewangan yang amat terkenal menggunakan kaedah silang tabulasi untuk mendapatkan skor kewangan literasi dalam kalangan orang awam.

157 Categrical data ialah data yang boleh dibahagikan kepada beberapa kumpulan. 
17. Seterusnya, Jadual 18 sehingga 21 adalah mengenai silang tabulasi di antara demografik dan pemahaman mengenai pinjaman bebas riba. Akhir sekali, Jadual 22 sehingga 25 membutirkan tentang demografik mahasiswa dan perbelanjaan berhemah.

\section{Silang Tabulasi antara Demografik dan Pemahaman Mengenai Zakat}

Jadual 10: Respons Mahasiswa Islam mengikut jurusan bagi soalan zakat

"Pelajar yang berlatarbelakangkan keluarga yang kaya dan mempunyai

sumber kewangan yang mantap, tapi masih mendapat tajaan dari institusi zakat. Adakah anda merasakan pelajar ini patut menolaknya?"

\begin{tabular}{lccc}
\hline \multicolumn{1}{c}{ Jurusan } & Jumlah responden (N=224) & $\begin{array}{c}\text { Peratusan "Tidak } \\
\text { Patut" mengikut } \\
\text { Jurusan (\%)* }\end{array}$ \\
\hline Syariah (N=86) & Patut & Tidak Patut & \\
Usuluddin (N=78) & 73 & 13 & $15 \%$ \\
Pengajian \& Pendidikan & 48 & 30 & $38 \%$ \\
Islam (N=60) & 32 & 28 & $47 \%$ \\
\hline
\end{tabular}

Sumber Data Primer: Md Sapir, Ana Shakirah, 'Islamic Financial Literacy among Malaysian Undergraduates.'

* Jumlah responden yang menjawab TIDAK PATUT dibahagikan dengan Jumlah Keseluruhan mahasiswa dalam setiap jurusan. Contoh: (Tidak Patut / Jumlah pelajar Syariah) x 100.

Jadual 11: Respons Mahasiswa Islam mengikut sumber kewangan pembelajaran bagi soalan zakat "Pelajar yang berlatarbelakangkan keluarga yang kaya dan mempunyai sumber kewangan yang mantap, tapi masih mendapat tajaan dari institusi zakat. Adakah anda merasakan pelajar ini patut menolaknya?"

\begin{tabular}{|c|c|c|c|}
\hline \multirow[t]{2}{*}{$\begin{array}{c}\text { Sumber kewangan } \\
\text { pembelajaran }\end{array}$} & \multicolumn{2}{|c|}{$\begin{array}{l}\text { Jumlah responden } \\
\qquad(\mathrm{N}=\mathbf{2 2 4})\end{array}$} & \multirow{2}{*}{$\begin{array}{l}\text { Peratusan "Tidak } \\
\text { Patut" mengikut } \\
\text { Sumber kewangan } \\
\text { pembelajaran (\%) }\end{array}$} \\
\hline & Patut & Tidak Patut & \\
\hline $\begin{array}{l}\text { Menggunakan wang persendirian } \\
(\mathrm{N}=62)\end{array}$ & 50 & 12 & $19 \%$ \\
\hline $\begin{array}{l}\text { Ibu Bapa menampung } \\
\text { keseluruhan pembelajaran }(\mathrm{N}=22)\end{array}$ & 13 & 9 & $41 \%$ \\
\hline
\end{tabular}




$\begin{array}{lccc}\text { Mendapat tajaan biasiswa }(\mathrm{N}=41) & 33 & 8 & 20 \% \\ \begin{array}{l}\text { Menggunakan pelan Pendidikan } \\ (\mathrm{N}=3)\end{array} & 3 & 0 & - \\ \begin{array}{l}\text { Mendapat pinjaman Pendidikan } \\ (\mathrm{N}=96)\end{array} & 69 & 27 & 28 \%\end{array}$

Sumber Data Primer: Md Sapir, Ana Shakirah, 'Islamic Financial Literacy among Malaysian Undergraduates.'

Jadual 12: Respons Mahasiswa Islam mengikut jenis-jenis pinjaman bagi soalan zakat "Pelajar yang berlatarbelakangkan keluarga yang kaya dan mempunyai sumber kewangan yang mantap, tapi masih mendapat tajaan dari institusi zakat. Adakah anda merasakan pelajar ini patut menolaknya?"

\begin{tabular}{|c|c|c|c|}
\hline \multirow[t]{2}{*}{ Jenis-jenis pinjaman } & \multicolumn{2}{|c|}{ Jumlah responden ( $N=96)$} & \multirow{2}{*}{$\begin{array}{c}\text { Peratusan "Tidak } \\
\text { Patut" mengikut } \\
\text { Jenis-jenis } \\
\text { pinjaman } \\
(\%) \\
\end{array}$} \\
\hline & Patut & Tidak Patut & \\
\hline $\begin{array}{l}\text { Perbadanan Tabung Pendidika } \\
\text { Tinggi Nasional (PTPTN) } \\
(\mathrm{N}=91)\end{array}$ & 67 & 24 & $26 \%$ \\
\hline Pinjaman Bank $(\mathrm{N}=3)$ & 3 & 0 & - \\
\hline $\begin{array}{l}\text { Pinjaman dari kaum kerabat } \\
(\mathrm{N}=2)\end{array}$ & 2 & 0 & - \\
\hline
\end{tabular}

Sumber Data Primer: Md Sapir, Ana Shakirah, 'Islamic Financial Literacy among Malaysian Undergraduates.' 
Jadual 13: Respons Mahasiswa Islam mengikut cara membelanjakan sumber kewangan pendidikan bagi soalan zakat "Pelajar yang berlatarbelakangkan keluarga yang kaya dan mempunyai sumber kewangan yang mantap, tapi masih mendapat tajaan dari institusi zakat. Adakah anda merasakan pelajar ini patut menolaknya?"

\begin{tabular}{cccc}
\hline $\begin{array}{c}\text { Cara membelanjakan } \\
\text { sumber kewangan } \\
\text { pendidikan }\end{array}$ & $\begin{array}{c}\text { Jumlah responden } \\
\mathbf{( N = 2 2 4 )}\end{array}$ & $\begin{array}{c}\text { Peratusan "Tidak } \\
\text { Patut" mengikut Cara } \\
\text { membelanjakan sumber } \\
\text { kewangan pendidikan (\%) }\end{array}$ \\
\hline & Patut & $\begin{array}{c}\text { Tidak } \\
\text { Patut }\end{array}$ & \\
Yuran pengajian (N=189) & 139 & 50 & $26 \%$ \\
Kos Sara Hidup (N=32) & 25 & 7 & $22 \%$ \\
Hiburan (N=3) & 3 & 0 & - \\
\hline
\end{tabular}

Sumber Data Primer: Md Sapir, Ana Shakirah, 'Islamic Financial Literacy among Malaysian Undergraduates.'

Jadual 10 sehingga 13 memberikan satu keputusan yang menarik. Didapati mahasiswa APIUM daripada Pengajian \& Pendidikan Islam yang dibiayai sepenuhnya oleh ibu bapa mereka berpendapat bahawa pelajar dari latar belakang keluarga yang kaya, mempunyai sumber kewangan yang mantap dan beriman TIDAK PATUT menolak untuk menerima tajaan dari institusi zakat sekiranya diberi peluang dan kesempatan. Sejajar dengan pembiayaan kewangan mereka yang ditanggung sepenuhnya oleh ibu bapa dapat ditafsirkan bahawa mereka ini juga tergolong dalam golongan pelajar yang kaya atau tidak mempunyai masalah kewangan.

Selain itu, kaedah silang tabulasi juga dilihat memberikan keputusan lain yang tidak kurang menariknya. Pengetahuan mahasiswa Syariah dalam fiqh zakat $^{158}$ membantu mereka untuk lebih memahami bahawa kelestarian zakat perlu mendahulukan golongan asnaf yang lebih memerlukan.

$74 \%$ pelajar yang membuat pinjaman PTPTN untuk membiayai pendidikan juga dilihat cenderung untuk membantah sekiranya dana zakat diagihkan kepada pelajar dari latar belakang keluarga yang kaya menerima tajaan dari institusi zakat, refleksi daripada sokongan mereka agar tajaan zakat mendahulukan mereka yang susah.

$\overline{158}$ Di dalam fiqh zakat, pelajar pengajian Islam dikategorikan sebagai tergolong dalam asnaffi sabilillah dan layak menerima zakat walaupun dia orang berada. 


\section{Silang Tabulasi antara Demografik dan Pemahaman Mengenai Takaful}

Jadual 14: Respons Mahasiswa Islam mengikut jurusan bagi soalan takaful

"Seseorang itu TIDAK perlu membeli takaful sebagai insuran untuk tabungan kecemasan ketika menghadapi musibah di masa hadapan. Adakah anda bersetuju dengan penyataan ini?"

\begin{tabular}{lccc}
\hline \multicolumn{1}{c}{ Jurusan } & \multicolumn{2}{c}{ Jumlah responden (N=224) } & $\begin{array}{c}\text { Peratusan "Setuju" } \\
\text { mengikut Jurusan (\%) }\end{array}$ \\
\hline Syariah (N=86) & Setuju & Tidak Setuju & $17 \%$ \\
Usuluddin (N=78) & 15 & 71 & $13 \%$ \\
$\begin{array}{l}\text { Pengajian \& Pendidikan } \\
\text { Islam (N=60) }\end{array}$ & 10 & 68 & $13 \%$ \\
\hline
\end{tabular}

Sumber Data Primer: Md Sapir, Ana Shakirah, 'Islamic Financial Literacy among Malaysian Undergraduates.'

Jadual 15: Respons Mahasiswa Islam mengikut sumber kewangan bagi soalan takaful "Seseorang itu tidak perlu membeli takaful sebagai insuran untuk tabungan kecemasan ketika menghadapi musibah di masa hadapan. Adakah anda bersetuju dengan penyataan ini?"

\begin{tabular}{lccc}
\hline Sumber kewangan pembelajaran & Jumlah responden (N=224) & $\begin{array}{c}\text { Peratusan } \\
\text { Setuju” } \\
\text { mengikut } \\
\text { sumber } \\
\text { kewangan } \\
\text { pembelajaran } \\
\text { (\%) }\end{array}$ \\
\hline $\begin{array}{l}\text { Menggunakan wang persendirian } \\
\text { (N=62) }\end{array}$ & Setuju & Tidak Setuju & \\
$\begin{array}{l}\text { Ibu Bapa menampung keseluruhan } \\
\text { pembelajaran (N=22) }\end{array}$ & 6 & 51 & $18 \%$ \\
$\begin{array}{l}\text { Mendapat tajaan biasiswa (N=41) } \\
\begin{array}{l}\text { Menggunakan pelan Pendidikan } \\
\text { (N=3) }\end{array}\end{array}$ & 5 & 16 & $27 \%$ \\
$\begin{array}{l}\text { Mendapat pinjaman Pendidikan } \\
\text { (N=96) }\end{array}$ & 12 & 36 & $12 \%$ \\
\hline
\end{tabular}

Sumber Data Primer: Md Sapir, Ana Shakirah, 'Islamic Financial Literacy among Malaysian Undergraduates.' 
Jadual 16: Respons Mahasiswa Islam mengikut jenis-jenis pinjaman bagi soalan takaful "Seseorang itu tidak perlu membeli takaful sebagai insuran untuk tabungan kecemasan ketika menghadapi musibah di masa hadapan. Adakah anda bersetuju dengan penyataan ini?"

\begin{tabular}{lccc}
\hline \multicolumn{1}{c}{ Jenis-jenis pinjaman } & Jumlah responden (N=96) & $\begin{array}{c}\text { Peratusan } \\
\text { "Setuju" } \\
\text { mengikut jenis- } \\
\text { jenis pinjaman } \\
\text { (\%) }\end{array}$ \\
\hline $\begin{array}{l}\text { Petuju } \\
\text { Nasional (PTPTN) (N=91) }\end{array}$ & 13 & $\begin{array}{c}\text { Tidak } \\
\text { Setuju }\end{array}$ & \\
$\begin{array}{l}\text { Pinjaman Bank (N=3) } \\
\text { Pinjaman dari kaum kerabat (N=2) }\end{array}$ & 0 & 78 & $14 \%$ \\
\hline
\end{tabular}

Sumber Data Primer: Md Sapir, Ana Shakirah, 'Islamic Financial Literacy among Malaysian Undergraduates'

Jadual 17: Respons Mahasiswa Islam mengikut cara membelanjakan sumber kewangan pendidikan bagi soalan takaful, "Seseorang itu tidak perlu membeli takaful sebagai insuran untuk tabungan kecemasan ketika menghadapi musibah di masa hadapan. Adakah anda bersetuju dengan penyataan ini?"

\begin{tabular}{|c|c|c|c|}
\hline \multirow{2}{*}{$\begin{array}{l}\text { Cara membelanjakan sumber } \\
\text { kewangan pendidikan }\end{array}$} & \multicolumn{2}{|c|}{ Jumlah responden $(\mathrm{N}=\mathbf{2 2 4})$} & \multirow{2}{*}{$\begin{array}{c}\text { Peratusan "Setuju" } \\
\text { mengikut Cara } \\
\text { membelanjakan } \\
\text { sumber kewangan } \\
\text { pendidikan }(\%)\end{array}$} \\
\hline & Setuju & Tidak Setuju & \\
\hline Yuran pengajian $(\mathrm{N}=189)$ & 29 & 160 & $15 \%$ \\
\hline Kos Sara Hidup (N=32) & 5 & 27 & $16 \%$ \\
\hline Hiburan $(\mathrm{N}=3)$ & 0 & 3 & - \\
\hline
\end{tabular}

Sumber Data Primer: Md Sapir, Ana Shakirah, 'Islamic Financial Literacy among Malaysian Undergraduates'

Jadual 14 sehingga 17 juga memberikan satu keputusan yang luar jangkaan apabila 17\% mahasiswa jurusan Syariah, yang membiayai yuran pengajian dan kos sara hidup menggunakan tajaan 100\% daripada ibu bapa 
mereka berpendapat seseorang itu bersetuju bahawa melanggan takaful tidak diperlukan sebagai tabungan kecemasan ketika menghadapi musibah di masa hadapan. Ia juga ada kemungkinan bahawa mereka tidak memahami tentang konsep usaha, tawakal dan redha yang amat sinonim dengan objektif takaful ditubuhkan.

Pemahaman mengenai takaful sejajar dengan pemahaman sebenar konsep tawakkal. Dua perkara asas tawakkal gabungan usaha sehabis baik dan penyerahan kepada Allah SWT. Allah SWT berfirman di dalam al-Quran:

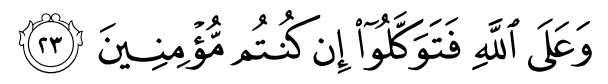

“...dan kepada Allah jualah hendaklah kamu berserah (setelah kamu bertindak menyerang), jika benar kamu orang-orang yang beriman."

(Surah al-Mā'idah, 5: 23)

Nabi SAW juga bersabda:

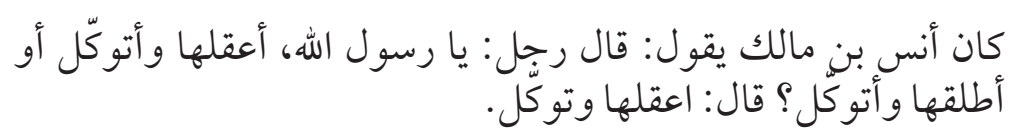

"Sayyiduna Anas meriwayatkan bahawa seorang lelaki telah bertanya kepada Rasulullah: "Adakah aku menambat (haiwanku) dan aku bertawakkal? Atau aku melepaskannya dan aku bertawakkal?" Nabi SAW menjawab: "Tambatlah ia dan bertawakkallah!"” 159

Segala bentuk perbuatan yang terjadi merupakan kehendak dan kuasa Allah tetapi masih lagi diusahakan oleh individu tersebut. Manakala redha merupakan perkara yang patut seorang mukmin lakukan selepas dirinya sudah berikhtiar dan tawakal. Syeikh Ahmad Zarruq mendefinisikan redha sebagai menerima sesuatu musibah itu dengan tenang dan berlapang dada. ${ }^{160}$

Aplikasi usaha, tawakal dan redha ini dalam melanggan takaful dapat dilihat sebagai satu usaha meminimalkan risiko yang mungkin terjadi pada masa hadapan, dan usaha ini diiringi dengan tawakal. Melanggan takaful sebagai penyediaan pada waktu kecemasan di masa hadapan dapat membuatkan

159 Muḥammad Ibn 'Īsā Ibn Sawrah al-Tirmidhī, Sunan Tirmidhī, vol. 4 (Bayrūt: Dār al-Gharb al-Islāmī, 1998), 249, 'Bāb Șifat al-Qiyāmah,' no. hadis 2517.

160 Nizār Ḥammadī, al-Ta 'rīfāt al-Zarrūqiyyah li al-Haqā'iq al-Sūfiyyah (Tunisia: Dār al-Imām Ibn 'Arafah, 2017), 42. 
seseorang itu berupaya berlapang dada dengan apa yang telah berlaku apabila sesuatu telah terjadi. ${ }^{161}$

Berdasarkan definisi tawakkal dan redha ini dapat difahami bahawa terdapat nisbah "mutlak umum dan khusus"162 antara dua perkara ini; Jika diteliti, ternyata bahawa tawakkal lebih umum kerana ia merangkumi keadaan sebelum dan ketika terjadi sesuatu, manakala redha pula hanya merangkumi keadaan ketika terjadi sesuatu. ${ }^{163}$

161 Terdapat empat nisbah antara dua lafaz yang berbeza, iaitu; a) Kontradiksi: makna sesuatu lafaz bercanggah dengan makna lafaz lain, b) Sama rata: makna sesuatu lafaz sama dengan makna lafaz lain, c) Mutlak umum dan khusus: makna sesuatu lafaz mengandungi makna lafaz lain, namun lafaz lain tidak mengandung makna lafaz tadi, d) Umum dan khusus dari satu sisi: kedua-dua lafaz mengandungi sebahagian makna lafaz lain. Lihat Muhammad Rị̣ā al-Muẓaffar, al-Manțiq (Lubnan: Dār al-Ta'rīf li al-Maṭbū'āt, 2006), 68. Ini berdasarkan pendapat yang lebih kukuh yang mengatakan bahawa redha adalah keadaan ketika ditimpa musibah, bukanlah setelah musibah tersebut berlalu. Contohnya, orang yang menerima dengan hati yang terbuka ketika mendapat perkhabaran kematian orang yang disayanginya; dikira sebagai orang yang redha, bukan yang telah meratap dan meraung terlebih dahulu, dan setelah seminggu barulah dia menerima realiti kematian itu.

162 Terdapat empat nisbah antara dua lafaz yang berbeza, iaitu; a) Kontradiksi: makna sesuatu lafaz bercanggah dengan makna lafaz lain, b) Sama rata: makna sesuatu lafaz sama dengan makna lafaz lain, c) Mutlak umum dan khusus: makna sesuatu lafaz mengandungi makna lafaz lain, namun lafaz lain tidak mengandungi makna lafaz tadi, d) Umum dan khusus dari satu sisi: kedua-dua lafaz mengandungi sebahagian makna lafaz lain. Lihat Muḥammad Rị̣a al-Muẓaffar, al-Manțiq, 68.

163 Ini berdasarkan pendapat yang lebih kukuh yang mengatakan bahawa redha adalah keadaan ketika ditimpa musibah, bukanlah setelah musibah tersebut berlalu. Contohnya, orang yang menerima dengan hati yang terbuka ketika mendapat perkhabaran kematian orang yang disayanginya; dikira sebagai orang yang reda, bukan yang telah meratap dan meraung terlebih dahulu, dan setelah seminggu barulah dia menerima realiti kematian itu. 
Rajah 1: Adaptasi Kerangka Usaha, Tawakal dan Redha dalam melanggani Takaful

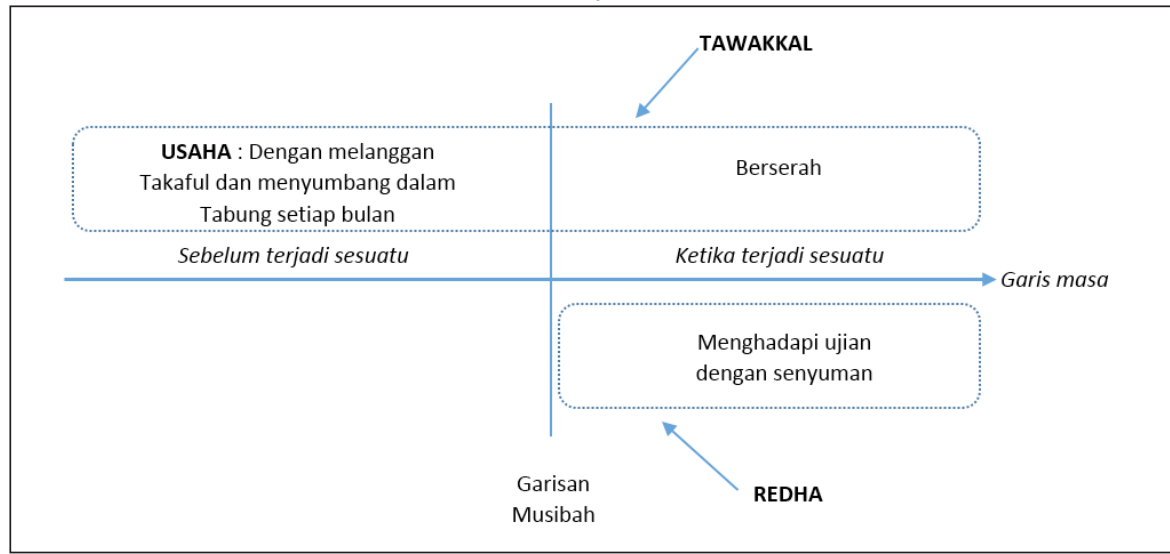

Sumber: Nizār Hammad̄̄, al-Ta'rīfāt al-Zarrūqiyyah li al-Ḥaqā’iq al-Sūfiyyah, dan Muhammad Rị̣ā al-Muẓaffar, al-Manțiq.

Seseorang itu berusaha melanggani takaful kerana ia percaya bahawa takaful adalah instrumen yang paling efektif bagi mengurangkan risiko apabila terjadinya musibah. Namun demikian, dia tidak boleh beranggapan bahawa hanya takaful saja yang mampu meminimalkan risiko sehingga menafikan alternatif dan usaha -usaha yang lain. Pada masa kini penganjuran takaful untuk diperkenalkan oleh Institusi Kewangan Islam di Malaysia didapati sebagai salah satu bentuk ikhtiar yang efektif bagi mengurangkan bebanan yang dialami setelah musibah terjadi sekaligus dapat mempraktikkan tawakkal dan redha dengan lebih berkesan.

Selain itu, secara keseluruhannya, pengkaji mendapati sambutan untuk melanggan takaful tidak menggalakkan dalam kalangan mahasiswa Akademi Pengajian Islam tanpa mengira mereka daripada latar belakang keluarga kaya atau miskin. Ini berdasarkan informasi yang terdapat di Jadual 7. Sekiranya ibu bapa mahasiswa sendiri tidak terdedah kepada Pelan Pendidikan anak-anak, ada kemungkinan bahawa mahasiswa tidak dapat memahami kepentingan untuk melanggan takaful. Di samping itu, berdasarkan Jadual 9, keutamaan untuk membiayai yuran pengajian dan kos sara hidup terutamanya bagi pelajar 
luar kampus mungkin menyebabkan hasrat mahasiswa Akademi Pengajian Islam untuk membayar langganan takaful setiap bulan dilihat membebankan. ${ }^{164}$

\section{Silang Tabulasi antara Demografik dan Pemahaman Mengenai Pinjaman Bebas Riba}

Jadual 18: Respons Mahasiswa Islam mengikut jurusan bagi soalan pinjaman, "Seseorang pelajar pengajian Islam yang miskin terpaksa menerima tajaan pinjaman pelajaran yang mempunyai unsur unsur riba kerana tidak mampu untuk membayar yuran pengajian di universiti yang mahal. Sekiranya anda berada dalam situasi ini, adakah anda juga akan menerima tajaan tersebut?"

\begin{tabular}{cccc}
\hline Jurusan & \multicolumn{2}{c}{ Jumlah responden (N=224) } & $\begin{array}{c}\text { Peratusan "Terima" } \\
\text { mengikut Jurusan } \\
\mathbf{( \% )}\end{array}$ \\
\hline Syariah (N=86) & Terima & Tidak Terima & $15 \%$ \\
Usuluddin (N=78) & 13 & 73 & $28 \%$ \\
$\begin{array}{c}\text { Pengajian \& Pendidikan } \\
\text { Islam (N=60) }\end{array}$ & 22 & 56 & $33 \%$ \\
\hline
\end{tabular}

Sumber Data Primer: Md Sapir, Ana Shakirah, 'Islamic Financial Literacy among Malaysian Undergraduates.'

* Secara spesifik, 54\% mahasiswa dari jurusan Pendidikan Islam menyatakan kesediaan untuk menerima pinjaman yang berunsurkan riba. Tetapi mereka tidak menyatakan sebabsebab penerimaan itu kerana mereka tidak faham maksud Pinjaman Konvensional dalam bidang kewangan itu membawa maksud pinjaman yang berdasar pinjaman berbunga yang diharamkan oleh Islam. Dalam hal ini, pengkaji mendapati mahasiswa yang tidak dilengkapi dengan ilmu kewangan yang lengkap bakal terdedah kepada unsur unsur kewangan yang haram di sisi Syarak.

164 Berdasarkan temu bual pengkaji dengan Perunding Takaful yang berpengalaman berurusan dengan pelanggannya yang terdiri daripada mahasiswa Akademi Pengajian Islam. Lihat Nur Farzielayati Mohamed Nawawi (Perunding Takaful, Takaful Ikhlas Berhad), dalam temu bual beliau bersama penulis pada 15 Oktober 2016. Beliau boleh dihubungi di farzieyati@gmail.com 
Jadual 19: Respons Mahasiswa Islam mengikut sumber kewangan bagi soalan pinjaman, "Seseorang pelajar pengajian Islam yang miskin terpaksa menerima tajaan pinjaman pelajaran yang mempunyai unsur unsur riba kerana tidak mampu untuk membayar yuran pengajian di universiti yang mahal. Sekiranya anda berada dalam situasi ini, adakah anda juga akan menerima tajaan tersebut?"

\begin{tabular}{lccc}
\hline Sumber kewangan pembelajaran & Jumlah responden (N=224) & $\begin{array}{c}\text { Peratusan } \\
\text { "Terima" } \\
\text { mengikut } \\
\text { sumber } \\
\text { kewangan (\%) }\end{array}$ \\
\hline & Terima & Tidak Terima & \\
$\begin{array}{l}\text { Menggunakan wang persendirian } \\
\text { N=62) }\end{array}$ & 14 & 48 & $23 \%$ \\
$\begin{array}{l}\text { Ibu Bapa menampung keseluruhan } \\
\text { pembelajaran (N=22) }\end{array}$ & 6 & 16 & $27 \%$ \\
$\begin{array}{l}\text { Mendapat tajaan biasiswa (N=41) } \\
\text { Menggunakan pelan Pendidikan } \\
\text { (N=3) }\end{array}$ & 10 & 31 & $24 \%$ \\
$\begin{array}{l}\text { Mendapat pinjaman Pendidikan } \\
(\mathrm{N}=96)\end{array}$ & 0 & 3 & - \\
\hline
\end{tabular}

Sumber Data Primer: Md Sapir, Ana Shakirah, 'Islamic Financial Literacy among Malaysian Undergraduates.'

Jadual 20: Respons Mahasiswa Islam mengikut jenis-jenis pinjaman bagi soalan pinjaman, "Seseorang pelajar pengajian Islam yang miskin terpaksa menerima tajaan pinjaman pelajaran yang mempunyai unsur unsur riba kerana tidak mampu untuk membayar yuran pengajian di universiti yang mahal. Sekiranya anda berada dalam situasi ini, adakah anda juga akan menerima tajaan tersebut?"

\begin{tabular}{lccc}
\hline \multicolumn{1}{c}{ Jenis-jenis pinjaman } & Jumlah responden (N=96) & $\begin{array}{c}\text { Peratusan } \\
\text { "Terima" } \\
\text { mengikut jenis- } \\
\text { jenis pinjaman } \\
\text { (\%) }\end{array}$ \\
\hline & Terima & Tidak Terima & \\
$\begin{array}{l}\text { Perbadanan Tabung Pendidikan } \\
\text { Tinggi Nasional (PTPTN) }(\mathrm{N}=91)\end{array}$ & 25 & 66 & $27 \%$ \\
Pinjaman Bank (N=3) & 0 & 3 & -
\end{tabular}


Pinjaman dari kaum kerabat $(\mathrm{N}=2)$

Sumber Data Primer: Md Sapir, Ana Shakirah, 'Islamic Financial Literacy among Malaysian Undergraduates.'

Jadual 21: Respons Mahasiswa Islam mengikut cara membelanjakan sumber kewangan pendidikan bagi soalan pinjaman, "Seseorang pelajar pengajian

Islam yang miskin terpaksa menerima tajaan pinjaman pelajaran yang mempunyai unsur unsur riba kerana tidak mampu untuk membayar yuran pengajian di universiti yang mahal. Sekiranya anda berada dalam situasi ini, adakah anda juga akan menerima tajaan tersebut?"

\begin{tabular}{cccc}
\hline $\begin{array}{c}\text { Cara membelanjakan } \\
\text { sumber kewangan } \\
\text { pendidikan }\end{array}$ & Jumlah responden $(\mathbf{N = 2 2 4 )}$ & $\begin{array}{c}\text { Peratusan "Terima" } \\
\text { mengikut Cara } \\
\text { membelanjakan } \\
\text { sumber kewangan } \\
\text { pendidikan (\%) }\end{array}$ \\
\hline Yuran pengajian $(\mathrm{N}=189)$ & Terima & Tidak Terima & $23 \%$ \\
Kos Sara Hidup $(\mathrm{N}=32)$ & 12 & 145 & $38 \%$ \\
Hiburan $(\mathrm{N}=3)$ & 3 & 20 & $100 \%$ \\
\hline
\end{tabular}

Sumber Data Primer: Md Sapir, Ana Shakirah, 'Islamic Financial Literacy among Malaysian Undergraduates.'

Jadual 18 hingga Jadual 21 juga memberikan satu keputusan yang luar jangkaan apabila 33\% mahasiswa Pengajian dan Pendidikan Islam yang menerima tajaan kewangan sepenuhnya untuk membiayai pendidikan mereka di kampus dan juga memprioritikan perbelanjaan mereka kepada hiburan menyatakan kesediaan mereka untuk menerima pinjaman yang berunsurkan riba untuk membayar yuran pengajian di universiti yang mahal. Keputusan ini tidak dijangkakan oleh pengkaji kerana berpendapat bahawa mahasiswa Pengajian dan Pendidikan Islam sepatutnya lebih berhati-hati agar tidak berurusan dengan sesuatu yang diharamkan oleh agama. Tambahan pula, pinjaman yang sepatutnya untuk kegunaan mendesak, dirancangkan untuk hiburan.

Berbeza dengan situasi apabila seseorang pelajar pengajian Islam yang miskin terpaksa menerima tajaan pinjaman pelajaran yang mempunyai unsur unsur riba kerana tidak mampu untuk membayar yuran pengajian di universiti yang mahal, kita perlu melihatnya dari beberapa sudut. Asas pegangan ini terdapat dalam al-Quran sepertimana berikut: 


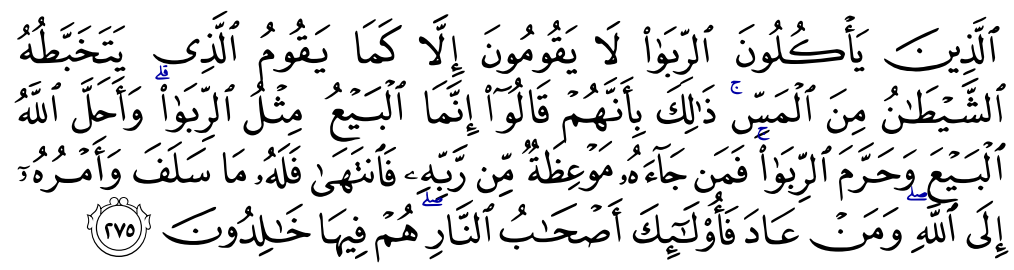

"Orang-orang yang memakan (mengambil) riba itu tidak dapat berdiri betul melainkan seperti berdirinya orang yang dirasuk Syaitan dengan terhuyung-hayang kerana sentuhan (Syaitan) itu. Yang demikian ialah disebabkan mereka mengatakan: "Bahawa sesungguhnya berniaga itu sama sahaja seperti riba". Padahal Allah telah menghalalkan berjual-beli (berniaga) dan mengharamkan riba. Oleh itu sesiapa yang telah sampai kepadanya peringatan (larangan) dari Tuhannya lalu ia berhenti (dari mengambil riba), maka apa yang telah diambilnya dahulu (sebelum pengharaman itu) adalah menjadi haknya, dan perkaranya terserahlah kepada Allah. Dan sesiapa yang mengulangi lagi (perbuatan mengambil riba itu) maka itulah ahli neraka, mereka kekal di dalamnya."

(Surah al-Baqarah, 2: 275)

Di sini jelas bahawa individu ini mungkin memahami masalah riba dalam pinjaman pendidikannya, berdasarkan ilmu yang dipelajari dalam pengajian Islam. Isu ini berkisar dalam hal berkaitan dengan fiqh dan sekiranya pakar dalam bidang fiqh kewangan membenarkannya untuk menerima tajaan itu atas faktor dharuriyyah, maka pelajar itu perlu taat akan saranan pakar tersebut. Inilah penzahiran ketaatannya kepada Allah SWT, Rasul dan ulil amri dari kalangan muslimin. Ulil amri yang dimaksudkan di sini adalah pemerintah dan para ulama.

Apabila mengambil kira sistem kewangan Islam di Malaysia yang sudah mantap dan sofistikated, ${ }^{165}$ pengkaji tidak menemui sebarang hal dharuriyyah sehingga menyebabkan mahasiswa miskin sanggup untuk membuat pinjaman pendidikan dari sistem kewangan konvensional. Apabila dibandingkan dengan $85 \%$ pelajar Syariah yang rata-rata mempunyai pengetahuan formal mengenai ilmu kewangan, pengkaji mendapati bahawa pendedahan individu Muslim terhadap ilmu kewangan juga mampu menjadi benteng kepada seseorang daripada mengambil sesuatu yang mempunyai unsur unsur yang bertentangan

165 Sistem kewangan Islam di Malaysia telah diiktiraf sebagai sistem yang terbaik di dunia. Lihat The Banker, Top Islamic Financial Institutions (Dubai: Divanna, J. \& King, James, 2015), 14. 
dengan Syarak. Pengetahuan formal mengenai ilmu kewangan ini bukan lagi dikira sebagai ilmu fardhu kifayah, tetapi ia adalah ilmu fardhu ain yang wajib dipelajari oleh individu Muslim jika dia perlu melakukan muamalat kewangan seperti pinjaman dan lain-lain. ${ }^{166}$

\section{Silang Tabulasi antara Demografik dan Perbelanjaan Berhemah}

Jadual 22: Respons Mahasiswa Islam soalan perbelanjaan berhemah, "Walaupun seseorang itu kaya dan mempunyai sumber kewangan yang banyak, dia masih lagi perlu berjimat cermat dan tidak membazir. Adakah anda bersetuju dengan penyataan ini?"

\begin{tabular}{lccc}
\hline \multicolumn{1}{c}{ Jurusan } & \multicolumn{2}{c}{ Jumlah responden (N=224) } & $\begin{array}{c}\text { Peratusan "Tidak } \\
\text { Setuju" mengikut } \\
\text { Jurusan (\%) }\end{array}$ \\
\hline & Setuju & Tidak Setuju & \\
Syariah $(\mathrm{N}=86)$ & 83 & 3 & $3 \%$ \\
Usuluddin $(\mathrm{N}=78)$ & 77 & 1 & $1 \%$ \\
$\begin{array}{l}\text { Pengajian \& Pendidikan Islam } \\
\text { (N=60) }\end{array}$ & 59 & 1 & $2 \%$ \\
\hline
\end{tabular}

Sumber Data Primer: Md Sapir, Ana Shakirah, 'Islamic Financial Literacy among Malaysian Undergraduates.'

166 Individu Muslim yang ingin melaksanakan sesuatu pekerjaan atau perbuatan wajib mengetahui batasan syariat berkaitan dengan pekerjaan atau perbuatan tersebut agar dia tidak melakukan hal yang haram di sisi syariat. Contohnya, orang yang ingin menjual insuran atau melanggannya mestilah mengetahui hukum-hakam berkaitan insuran kerana dia wajib mengikut perintah syariat dan meninggalkan hal yang dilarang dalam urusan tersebut. Kewajipan mengikut perintah dan meninggalkan larangan ini secara tidak langsung telah mewajibkan individu tersebut mempelajari ilmu berkenaan insuran dan muamalat kewangan. Dengan ini, ilmu insuran dan kewangan telah menjadi satu fardhu ain atas diri individu tersebut, tetapi tidak wajib keatas individu-individu lain yang tidak terlibat dengan sebarang urusan insuran dan kewangan. Lihat Imam al-Ghazali, Penerangan Ilmu yang Dihukumi Sebagai Fardhu Ain, dalam kitab Ihya' Ulumiddin (Jeddah: Darul Minhaj, 2011), 54-61. 
Jadual 23: Respons Mahasiswa Islam mengikut sumber kewangan bagi soalan perbelanjaan berhemah, "Walaupun seseorang itu kaya dan mempunyai sumber kewangan yang banyak, dia masih lagi perlu berjimat cermat dan tidak membazir. Adakah anda bersetuju dengan penyataan ini?"

\begin{tabular}{lccc}
\hline Sumber Kewangan Pembelajaran & Jumlah responden (N=224) & $\begin{array}{c}\text { Peratusan } \\
\text { "Tidak Setuju" } \\
\text { mengikut } \\
\text { sumber } \\
\text { kewangan (\%) }\end{array}$ \\
\hline $\begin{array}{l}\text { Menggunakan wang persendirian } \\
\text { (N=62) }\end{array}$ & Setuju & Tidak Setuju & \\
$\begin{array}{l}\text { Ibu Bapa menampung keseluruhan } \\
\text { pembelajaran (N=22) }\end{array}$ & 20 & 0 & - \\
$\begin{array}{l}\text { Mendapat tajaan biasiswa (N=41) } \\
\begin{array}{l}\text { Menggunakan pelan Pendidikan } \\
\text { (N=3) }\end{array}\end{array}$ & 39 & 2 & $9 \%$ \\
$\begin{array}{l}\text { Mendapat pinjaman Pendidikan } \\
\text { (N=96) }\end{array}$ & 3 & 0 & $5 \%$ \\
\hline
\end{tabular}

Sumber Data Primer: Md Sapir, Ana Shakirah, 'Islamic Financial Literacy among Malaysian Undergraduates'

Jadual 24: Respons Mahasiswa Islam mengikut jenis-jenis pinjaman bagi soalan perbelanjaan berhemah, "Walaupun seseorang itu kaya dan mempunyai sumber kewangan yang banyak, dia masih lagi perlu berjimat cermat dan tidak membazir. Adakah anda bersetuju dengan penyataan ini?"

\begin{tabular}{lccc}
\hline \multicolumn{1}{c}{ Jenis-jenis pinjaman } & Jumlah responden (N=96) & $\begin{array}{c}\text { Peratusan "Tidak } \\
\text { Setuju" mengikut } \\
\text { jenis-jenis pinjaman } \\
\text { (\%) }\end{array}$ \\
\hline $\begin{array}{l}\text { Perbadanan Tabung Pendidikan } \\
\text { Tinggi Nasional (PTPTN) (N=91) }\end{array}$ & 90 & 1 & $1 \%$ \\
Pinjaman Bank (N=3) & 3 & 0 & - \\
Pinjaman dari kaum kerabat (N=2) & 2 & 0 & - \\
\hline
\end{tabular}

Sumber Data Primer: Md Sapir, Ana Shakirah, 'Islamic Financial Literacy among Malaysian Undergraduates.' 
Jadual 25: Respons Mahasiswa Islam mengikut cara membelanjakan sumber kewangan pendidikan bagi soalan perbelanjaan berhemah, "Walaupun seseorang itu kaya dan mempunyai sumber kewangan yang banyak, dia masih lagi perlu berjimat cermat dan tidak membazir. Adakah anda bersetuju dengan penyataan ini?

\begin{tabular}{cccc}
\hline $\begin{array}{c}\text { Cara membelanjakan sumber } \\
\text { kewangan pendidikan }\end{array}$ & $\begin{array}{c}\text { Jumlah responden } \\
(\mathbf{N = 2 2 4 )}\end{array}$ & $\begin{array}{c}\text { Peratusan "Tidak } \\
\text { Setuju" mengikut cara } \\
\text { membelanjakan sumber } \\
\text { kewangan pendidikan (\%) }\end{array}$ \\
\hline & Setuju & $\begin{array}{c}\text { Tidak } \\
\text { Setuju }\end{array}$ & \\
Yuran pengajian (N=189) & 186 & 3 & $2 \%$ \\
Kos Sara Hidup (N=32) & 42 & 0 & - \\
Hiburan (N=3) & 3 & 0 & - \\
\hline
\end{tabular}

Sumber Data Primer: Md Sapir, Ana Shakirah, 'Islamic Financial Literacy among Malaysian Undergraduates.'

Jadual 22 sehingga Jadual 25 membicarakan tentang demografik mahasiswa dan perbelanjaan berhemah. Soalan perbelanjaan berhemah ini yang paling disepakati oleh hampir kesemua mahasiswa Akademi Pengajian Islam. Masing-masing memahami bahawa seseorang yang kaya dan mempunyai sumber kewangan yang banyak masih lagi perlu berjimat cermat dan tidak membazir sebagai satu bentuk kesyukuran kepada Allah SWT di atas segala nikmat yang dikurniakan. Hal ini merujuk kepada makna kesyukuran walaupun seseorang itu kaya dan mempunyai sumber kewangan yang banyak, dia masih lagi perlu berjimat cermat dan tidak membazir. Kesyukuran sepertimana yang didefinisikan oleh Syeikh Ibn Kiran adalah perbuatan menggunapakai kesemua anggota badan yang dikurniakan oleh pemberi nikmat pada hal-hal yang disenangi (diredhai) oleh pemberi nikmat pada setiap atau keseluruhan waktu dan ketika. Kesyukuran dengan erti kata inilah yang dinamakan sebagai ketakwaan dan istiqamah. ${ }^{167}$

Namun begitu, pihak penganjur program perancangan kewangan untuk mahasiswa pengajian Islam masih perlu memberi perhatian kepada golongan mahasiswaaristokratyangmengambiljurusan Syariahyang dibiayaisepenuhnya oleh ibu bapa, tetapi dalam masa yang sama, mendapat tajaan biasiswa untuk menampung yuran pengajian yang dilihat mempunyai pandangan berbeza

167 Muhammad Ṭayyib bin 'Abd al-Majib Ibn Kiran, Sharh Muqaddimah al-Murshīd al-Mu 'in fì al-'Aqīdah (t.t.p.: Maṭba'ah al-Tawfiq, t.t.), 10. 
mengenai perbelanjaan berhemah. Ia berkemungkinan definisi perbelanjaan berhemah bagi mereka berbeza dengan yang diperbincangkan dalam artikel ini, jadi pengkaji menyeru agar kajian di masa hadapan memfokuskan kepada mahasiswa aristokrat yang mengambil jurusan pengajian Islam.

\section{PERBINCANGAN DAN IMPLIKASI}

Berdasarkan hasil kajian ini, didapati majoriti mahasiswa di Akademi Pengajian Islam bukanlah berasal dari golongan berada dan kebanyakan mereka tidak terdedah kepada pengurusan kewangan yang mantap oleh ibu bapa mereka. Ini dapat dilihat berdasarkan kepada $94.8 \%$ daripada responden yang mempunyai komitmen pinjaman pendidikan dari PTPTN untuk membayar yuran pengajian. Bagi mereka yang terpaksa menyewa di luar kampus, pinjaman PTPTN tidak dapat menampung sewa bulanan yang menyebabkan mereka terpaksa bekerja secara separuh masa. Situasi ini akan berbeza sekiranya ibu bapa mahasiswa juga terdedah kepada Pelan Pendidikan Kewangan jangka masa panjang untuk persediaan anak-anak mereka membiayai pengajian peringkat tinggi mereka. Tetapi, berdasarkan Jadual 3, pelan pendidikan ini tidak mendapat sambutan daripada ibu bapa mahasiswa APIUM.

\section{Pemahaman Kewangan Golongan Mahasiswa Aristokrat}

Analisa silang tabulasi memberi pattern yang mengejutkan. Peratusan yang tinggi dalam kalangan golongan mahasiswa yang kaya seolah-olah menuntut hak meritokrasi, ${ }^{168}$ yang senada dengan tuntutan golongan aristokrat, ${ }^{169} \mathrm{di}$ mana penajaan zakat perlu dinilai berdasarkan kebolehan, keupayaan, kecerdasan dan merit yang dipersembahkan menerusi sistem peperiksaan di institusi. Mahasiswa aristokrat ini yang pembiayaan pengajian mereka ditanggung sepenuhnya oleh ibu bapa dilihat banyak berbeza pandangan dengan keseluruhan pemahaman mahasiswa di APIUM yang rata-ratanya dari golongan yang kurang berkemampuan. Pengkaji melihat ini dari satu sudut positif di mana mahasiswa aristokrat yang mengambil jurusan pengajian Islam ini sebenarnya amat memahami dengan konsep agihan zakat kepada asnaf $f i$ sabilillah yang tidak meletakkan syarat khas untuk golongan berpendapatan rendah sahaja.

168 Konsep yang diperkenalkan oleh Michael Young, penulis buku Rise of Meritocracy, yang menjadi rujukan utama pemerintahan di Singapura.

169 Golongan bangsawan, kaya dan mempunyai kedudukan yang tinggi dalam masyarakat. Sila lihat Cambridge Dictionary, 'Aristocrat,' https://dictionary. cambridge.org/dictionary/english/aristocrat, dicapai pada 1 Mei 2020. 
Namun pengkaji berpendapat melalui hasil kajian ini, diharapkan pihak institusi zakat dapat memastikan hanya mahasiswa jurusan Pengajian \& Pendidikan Islam yang dikategorikan sebagai asnaf fakir dan miskin sahaja dapat menerima zakat dari institusi bagi mengelakkan pertikaian dan persoalan terhadap kredibiliti institusi zakat pada masa hadapan. Manakala, pihak pentadbiran Ijazah Dasar di APIUM perlu memastikan golongan yang memerlukan sahaja layak mendapat zakat. Ini kerana terdapat mahasiswa yang berlatarbelakangkan keluarga yang kaya juga telah menerima kupon makanan. ${ }^{170}$

Corak jawapan golongan mahasiswa aristokrat dari jurusan Syariah juga ternyata berbeza dengan yang lain apabila mereka sudah berasa selesa dengan saraan yang diberikan oleh ibu bapa mereka tanpa perlu memikirkan musibah pada masa hadapan. Dengan kewangan yang banyak, kuasa pembelian takaful sebenarnya berada di tangan mereka. Pengkaji berpendapat bahawa ia berkemungkinan ibu bapa mereka sudah menyediakan hibah harta yang dapat mereka gunakan apabila kecemasan. Pemilikan harta peribadi dan mengambil jurusan Syariah ternyata membuatkan pemahaman individu mengenai kewangan ternyata berbeza kerana mereka tiada keperluan mendesak untuk melanggani takaful dan juga berkemungkinan mempunyai solusi lain yang lebih ampuh untuk mengurangkan risiko apabila ditimpah musibah.

\section{LIMITASI KAJIAN DAN CADANGAN UNTUK KAJIAN HADAPAN}

Pemilihan Mahasiswa Akademi Pengajian Islam sebagai responden tidak memberikan hasil kajian yang memberansangkan mengenai soalan zakat, takaful dan perbelanjaan berhemah. Ini kerana majoriti mahasiswa APIUM bukanlah dari golongan berada dan tidak mempunyai kuasa menentukan keputusan kewangan mereka sendiri. Tambahan pula, mereka tidak didedahkan dengan takaful dan Pelan Pendidikan Jangka Masa Panjang oleh ibu bapa mereka. Pendedahan terhadap takaful dan Pelan Pendidikan Jangka Masa Panjang amat penting bagi mengkaji pemahaman kewangan Islam mereka dari

170 Berdasarkan pemerhatian pengkaji ketika menguruskan dana zakat tajaan sebuah badan korporat pada bulan Februari tahun 2018. Terdapat beberapa mahasiswa Akademi Pengajian Islam yang menerima kupon makanan mempunyai ibu bapa yang mempunyai kewangan yang mantap. Mahasiswa ini dikategorikan sebagai penerima kupon makanan kerana ibu bapa mereka dikategorikan sebagai "bekerja sendiri" yang pada perkiraan pentadbiran; ibu bapa mahasiswa ini tidak mempunyai kewangan yang tetap, sedangkan "bekerja sendiri" juga membawa maksud mempunyai perusahaan sendiri. Sebahagian mahasiswa ini menolak untuk menerima zakat dan mendahulukan rakan-rakan mereka yang lebih memerlukan, tetapi masih ramai juga menerimanya. 
sudut praktikal. Di peringkat nasional, usaha kerajaan memperkenalkan Skim Simpanan Pendidikan Nasional (SSPN-i) ${ }^{171}$ diharapkan dapat meningkatkan kefahaman mengenai kepentingan menabung untuk pengajian tinggi anakanak. Selain itu, kebanyakan mahasiswa Akademi Pengajian Islam tidak berkemampuan untuk melanggani takaful kerana mereka perlu menumpukan sumber kewangan kepada yuran pengajian, sedangkan langganan takaful seawal mungkin amat digalakkan bagi meningkatkan jumlah sumbangan ketika berlakunya musibah.

Walau bagaimanapun, kajian ini masih dapat menemukan pemahaman kewangan yang berbeza dalam kalangan mahasiswa yang ditaja sepenuhnya oleh ibu bapa mereka. Di dalam kajian ini, pengkaji menggelarkan mereka dengan gelaran mahasiswa aristokrat yang mempunyai karakteristik kaya, berpendidikan tinggi dan berstatus sosial tinggi. Pemahaman kewangan mereka dilihat amat berbeza dapat dilihat sekiranya mahasiswa aristokrat ini mengikuti jurusan Syariah dan juga mendapat tajaan biasiswa. Walaupun golongan ini tidak mendominasi APIUM dan mempunyai peratusan yang amat kecil, tetapi tidak keterlaluan apabila pengkaji melihat ia sejajar dengan laporan Global Wealth Report 2016 bahawa golongan kaya di dunia ini hanya $10 \%$ daripada populasi dunia tetapi mereka menguasai hampir 90\% harta di dunia. ${ }^{172}$ Pengkaji berpendapat bahawa golongan mahasiswa aristokrat di APIUM adalah berlatarbelakangkan keluarga yang berpendapatan dalam braket T20. ${ }^{173}$

171 Satu skim atau instrumen simpanan yang direka khas oleh Perbadanan Tabung Pendidikan Tinggi Nasional (PTPTN) bagi tujuan pendidikan tinggi. Skim yang ditawarkan adalah patuh Syariah yang menggunakan konsep "Wakalah Bil Istithmar" di mana pendeposit melantik PTPTN untuk menguruskan deposit mereka bagi tujuan pelaburan. Mulai 1 Januari 2012, para pelajar yang ingin memohon pinjaman pendidikan bagi membiayai pengajian mereka di Politeknik, IPTA atau IPTS adalah diwajibkan mempunyai akaun SSPN-i dengan simpanan minimum sepertimana yang ditetapkan oleh PTPTN.

172 Lihat Merdeka.com., 'Fakta-fakta dunia dikuasai hanya oleh segelintir orang kaya,' https://www.merdeka.com/uang/fakta-fakta-dunia-dikuasai-hanya-olehsegelintir-orang-kaya.html, dicapai pada 1 Mei 2020.

173 Kaji Selidik Kemudahan Asas dan Pendapatan Isi Rumah 2019 mengatakan kumpulan T20 ialah kelompok 20\% teratas dalam populasi di Malaysia yang mempunyai pendapatan isi rumah median yang sekurang-kurangya RM15,301 sebulan. Lihat Jabatan Perangkaan Malaysia, 'Kaji Selidik Kemudahan Asas dan Pendapatan Isi Rumah 2019’ https://www.dosm.gov.my/v1/index.php?r=column/ pdfPrev\&id=cE13dXFSRFVQL2IrTUhJNE5vRXRXZz09, dicapai pada 1 Ogos 2020 . 
Begitu juga dengan soalan mengenai perbelanjaan berhemah di mana kajian akan lebih bermakna sekiranya responden terdiri daripada mereka yang berlatarbelakangkan orang yang berharta kerana pengkaji mahu melihat pemahaman mereka tentang keperluan berjimat cermat ketika mereka mempunyai lebihan wang dari sudut praktikal. Dengan ini, pengkaji mencadangkan agar kajian ini dapat diperluaskan kepada populasi mahasiswa pengajian Islam yang berlatarbelakangkan keluarga berada yang belajar di Institusi Pengajian Swasta (tiada mendapat bantuan biasiswa dan membiayai sepenuhnya pengajian sendiri) atau mereka yang sudah berkerjaya supaya hasil kajian yang berbeza dapat dilihat.

Pemahaman Kewangan seseorang individu ini dapat dilihat dari perbezaan yang ketara di antara mahasiswa Akademi Pengajian Islam yang mengambil jurusan Syariah dengan Pengajian \& Pendidikan Islam dan Usuluddin. Ilmu kewangan yang banyak didedahkan kepada penuntut Syariah menerusi Fiqh Muamalat menjadikan mereka lebih kuat untuk menghadapi anasir-anasir yang merosakkan akidah yang masuk melalui praktikal kewangan.

Di samping itu, kami mendapati bahawa Rajah 1 amat sesuai untuk digunapakai oleh para perunding takaful bagi memberi penerangan mengenai kepentingan melanggan takaful kepada golongan yang berlatar belakangkan pendidikan agama berasaskan tradisional. Ini kerana, berdasarkan Jadual 3, ia memberi satu klu bahawa ibu bapa mahasiswa Islam tidak didedahkan dengan Pelan Pendidikan jangka masa panjang, Rajah 1 diharapkan dapat membantu perunding takaful untuk menerangkan bahawa takaful adalah salah satu usaha yang efektif yang diperkenalkan oleh Institusi Kewangan Islam di Malaysia dan selaras dengan Falsafah Kepercayaan Islam.

Mahasiswa Akademi Pengajian Islam yang menjadi responden bagi kajian ini mungkin telah ramai yang bergraduasi dan berkerjaya kerana kajian ini dijalankan pada tahun 2016. Jadi, diharapkan ia dapat menjadi satu tanda aras bagi Persatuan Alumni Universiti Malaya (PAUM) dan Pentadbiran Universiti Malaya untuk melihat kebolehpasaran para graduan Universiti Malaya berserta dengan tabiat kewangan mereka selepas graduasi. Ini kerana tabiat kewangan yang betul dan mengikut Syarak bakal memberi manfaat kepada Universiti di dalam bentuk zakat dan wakaf. Sumber zakat dan wakaf daripada para alumni Muslim bakal memberi impak kepada pembangunan mahasiswa Islam di Universiti Malaya.

\section{RUJUKAN}

Abd. Hamid, M.H. \& Hassan, R., 'Akta Perkhidmatan Kewangan Islam 2013: Tinjauan Awal Kesannya dalam Industri Takaful,' Kanun: Jurnal Undang-Undang Malaysia, vol. 26/2 (2014): 254-267. 
Abd. Rahman, A. H., Abdullah, M.F. \& Ghazali, M.A., 'Wakalah Agihan Zakat Menerusi Perspektif Maqasid Syariah,' (Kertas kerja, $1^{\text {st }}$ Kedah International Zakat Conference, Lembaga Zakat Negeri Kedah, Kedah, 6 Ogos 2019).

Abdul Manap, N.M., 'Sustainable Food Security Through Zakat Fund in Malaysia,' (Kertas kerja, 1st Kedah International Zakat Conference, Lembaga Zakat Negeri Kedah, Kedah, 6 Ogos 2019).

Abdul Rahim, A.K., Ahmad Razimi, M.S. \& Ahmad, M.S., 'Zakat pertanian: Asas dan Perlaksanaan Semasa di Negeri Kedah Darulaman' (Kertas kerja, $1^{\text {st }}$ Kedah International Zakat Conference, Lembaga Zakat Negeri Kedah, Kedah, 6 Ogos 2019).

Abdul Rahman Hamzah \& Wan Fahmie Abdillah, 'Persepsi Pelajar Sarjana Muda Sains serta Pendidikan (Pengajian Islam) terhadap tanggungjawab kepimpinan dakwah di Universiti Teknologi Malaysia,' http://eprints. utm.my/id/eprint/10741/, dicapai pada 9 Ogos 2020.

Abdullah \& Anderson, 'Islamic Financial Literacy among Bankers in Kuala Lumpur,' Journal of Emerging Economies and Islamic Research, vol. 3/2 (2015): 1-16.

Abdullah, S., 'Zakat Harta Individu Berasaskan Nisab Emas: Kajian Syariah dan Perlaksanaannya di Selangor,' dalam Memperkasakan Kutipan dan Agihan Zakat di Malaysia, ed. Musa, Z. M., Ab Rahman, A., \& Abdul Wahab, A. (Nilai: Penerbit USIM, 2017), 217-228.

Abdullah, S., Mohammed, N.H., Salleh, S.M., Rashid, K.M. \& Kamal, S.S., 'Financial Literacy among UiTM's Students,' Journal of Applied Environmental and Biological Sciences, vol. 7/58 (2017): 31-36.

Agarwalla, S.K., Barua S.K., Jacob, J. \& Varma, J.R., 'Financial Literacy among Working Young Adults in Urban India,' World Development, vol. 67 (2015): 101-109.

Ahmad \& Wahid., 'Sumber zakat: perluasan terhadap harta yang diikhtilaf,' Jurnal Syariah, vol. 13 (2005): 135-162.

Ahmad Johari Sihes, Abdul Rahim Hamdan, Jamaluddin Ramli \& Nor Salis Samingan, 'Pengaruh pengetahuan agama ke atas amalan agama dan gaya hidup mahasiswa Islam Universiti Teknologi Malaysia,' http://eprints.utm.my/id/eprint/384/1/AhmadJohariSihes2006 Pengaruhpengetahuanagamakeatasamalan.pdf, dicapai pada 9 Ogos 2020. 
Ahmad, S., 'Agihan Zakat Merentasi Asnaf: Ke Arah Memperkasa Institusi Zakat,' (Kertas kerja, Persidangan Kebangsaan Ekonomi Malaysia, Kuantan, Pahang, 2-4 Jun 2009).

Ahmad, S.M. \& Mahadi, N.F., 'Sustainable Development Goals and The Role of Zakat' (Kertas kerja, 1st Kedah International Zakat Conference, Lembaga Zakat Negeri Kedah, Kedah, 6 Ogos 2019).

Ahmad, Shukri, Ahmad, Kamarudin, Abd Hamid, Solahuddin, Dahaman, Mohd Akram \& Mohamad Cusairi, Rafidah, 'Kedudukan Orang Kurang Upaya (OKU) dalam Agenda Kelestarian Agihan Zakat Negeri Kedah,' (Kertas kerja, 1st Kedah International Zakat Conference, Lembaga Zakat Negeri Kedah, Kedah, 6 Ogos 2019).

Ahmad-Zaluki \& Abdul Rahman, 'Kegunaan Wang Zakat untuk Pembangunan Asnaf Muallaf,' (Kertas kerja, 1 st Kedah International Zakat Conference, Lembaga Zakat Negeri Kedah, Kedah, 6 Ogos 2019).

AKPK, 'Jenis-jenis pinjaman', https://www.akpk.org.my/content/482-jenisjenis-pinjaman., dicapai pada 1 Mei 2020.

Aladdin, Y.H. \& Ahmad, A., 'Tahap Literasi Kewangan di Kalangan Mahasiswa,' (Kertas kerja, International Conference on Global Education V Global Education 2017, Commonwealth and Cultural Diversity, Universitas Ekasakti, Padang. 10-11 April 2017).

Al-Akiti, D.A., Akidah Ahli Iman (Selangor: Galeri Ilmu Sdn. Bhd., 2019).

Alhabshi, S.O., \& S. Abdul Razak, S.H., 'Takaful Insurance: Concept, History and Development Challenges.' in The Foundations of Islamic Banking: Theory, Practice and Education, ed. Mohamed Ariff \& Munawar Iqbal (Cheltenham, Glasglow: Edward Elgar Publishing Limited., 2011), 184207.

Alnaslah, E., 'M\&M's: Marriage and Money,' http://www.virtualmosque. com/islam-studies/hot-topics/mms-marriage-and-money/, dicapai pada 1 Mei 2020.

Alpari, 'Pattern' https://alpari.com/ms/beginner/glossary/pattern/, dicapai pada 1 Mei 2020.

Amiirah Raffick, 'Islamic Financial Literacy among QFIS Students' (Master Dissertation, Qatar Faculty of Islamic Studies, Hamad Bin Khalifa University, 2015).

Anjali Sane, 'Financial Literacy: Challenges for Indian Economy,' Journal of Commerce \& Management Thought, vol. 5/3 (2014): 475-487. 
Arif Fathillah Mohd Safar, 'Analisis Terhadap Elemen Maqasid Al-Syariah dalam Produk Takaful Ikhlas di Malaysia' (Disertasi Sarjana, Jabatan Fiqh and Usul, Akademi Pengajian Islam, Universiti Malaya, 2011).

Armstrong, T.S., Marlene, Z.., Cohen, K.A., Eriksen, L. \& Cleeland, C., 'Content Validity of Self-Report Measurement Instrument Instruments: An Illustration from the Development of the Brain Tumor Module of the M.D. Anderson Symptom Inventrory,' Oncology Nursing, vol. 32/3 (2005): 669-676.

Asian Institute of Finance, 'Understanding Gen Y: Bridging the Knowledge Gap of Malaysia’s Millennial,' http://www.aif.org.my/about-aif, dicapai pada 1 Mei 2020.

Asri, S., 'Budaya Menabung Rakyat Malaysia Masih Rendah,' https://www. bharian.com.my/berita/nasional/2018/09/479153/budaya-menabungrakyat-malaysia-masih-rendah, dicapai pada 1 Mei 2020.

Atkinson, Adele. \& Messy. Flore-Anne, 'Measuring Financial Literacy: Results of the OECD/International Network on Financial Education (INFE) Pilot Study,' OECD Working Papers on Finance, Insurance and Private Pensions, no. 15 (Paris, France: OECD Publishing, 2012).

Avard, S., Manton, E., English, D. \& Walker, J., 'The Financial Knowledge of College Freshmen,' College Student Journal, vol. 39, no. 2 (2005): 321-339.

Azmi, S.N., 'PTPTN tawar simpanan RM500 percuma RM500 untuk 500,000 pelajar,' https://www.bharian.com.my/bisnes/korporat/2018/05/422625/ ptptn-tawar-simpanan-rm500-percuma-rm500-untuk-500000-pelajar, diterbitkan pada 15 Mei 2018, dicapai pada 1 Mei 2020.

Bank Muamalat, 'Perbandingan antara perbankan Islam dan konvensional,' https://www.muamalat.com.my/downloads/media-room/publications/ Perbankan-ISLAM-\&-Konvensional-web.pdf, dicapai pada 1 Mei 2020.

Bankinginfo.com, ‘Apakah perbankan Islam?’ http://www1.bankinginfo.com. my/_system/media/downloadables/perbankan_islam.pdf, dicapai pada 1 Mei 2020.

Bigda, C., 'Mom Leads the Way in Shaping Financial Skills,' articles. chicagotribune.com/2011-06-17/news/sc-cons-0616-started 20110617_1_financial-skills-financial-literacy-financial-education, dicapai pada $\overline{1}$ Mei 2020. 
Calamato, M.P., 'Learning Financial Literacy in the Family,' (Master Dissertation, Department of Sociology, San José State University, California, USA, 2010).

Caldwell, 'Choosing between On and Off Campus Living Options,' https:// www.thebalance.com/choosing-between-on-and-off-campus-livingoptions-2386191, dicapai pada 1 Mei 2020.

Cambridge Dictionary, 'Aristocrat,' https://dictionary.cambridge.org/ dictionary/english/aristocrat, dicapai pada 1 Mei 2020.

Chaulagain, R. P., 'Contribution of Financial Literacy to behaviour,' Journal of Economics and Behavioral Studies, vol. 7/6 (2015): 61-71.

Chen, H. \& Volpe, R.P., 'An Analysis of Personal Financial Literacy Among College Students,' Financial Services Review, vol. 7/2 (1998): 107-128.

Clark, 'Why Fathers matter to their children's literacy,' National Literacy Trust, http://www.literacytrust.org.uk/assets/0000/0770/Father_review_2009. pdf, dicapai pada 1 Mei 2020.

Coffman, Julia, An Environmental Scan of Challenges, Criticism, Practices and Opportunities: Harvard Family Research Project (Harvard, U.S: Communications Consortium Media Center, 2002).

College Choice, 'What are the major expenses for students?' https:/www. collegechoice.net/college-life-3/what-are-the-major-expenses-forstudents/, dicapai pada 1 Mei 2020.

CompareHero.my., 'Compare Debt Consolidation Personal Loans,' https:// www.comparehero.my/personal-loan/debt-consolidation, dicapai pada 1 Mei 2020.

Cude, B.J., Lawrence,F.C., Lyons, A.C., Metzger, K., LeJeune, E., Marks, L., \& Matchtmes, K., 'College Students and Financial Literacy: What They Know and What We Need to Learn,' (Paper presented, Eastern Family Economics and Resource Management Association, Austin, Texas, 10 April 2006).

DirectLending.com.my, 'Mengapa kita membuat pinjaman?' http:/ www.insuranceinfo.com.my/learn_the_basics/types_of_takaful. php?intPrefLangID=2, dicapai pada $1 \overline{\text { Mei }} \overline{2} 020$.

Muhamad Razak Idris, 'Agamawan pemangkin majukan negara,' https:/www. bharian.com.my/kolumnis/2016/07/178595/agamawan-pemangkinmajukan-negara, dicapai pada 6 Ogos 2020.

Education planner.org (2011), 'Why save for your child's future?' www. educationplanner.org/parents/why-save.shtml, dicapai pada 1 Mei 2020. 
Eletrebi, M. F., Suleiman, H. and Abdul Aziz, M. N., 'The Developmental Objectives (Maqasid) of zakah institution in Kedah' (Kertas kerja, 1st Kedah International Zakat Conference, Lembaga Zakat Negeri Kedah, Kedah, 6 Ogos 2019).

fastweb., '31 Money saving tricks for students,' fastweb. http://www.fastweb. com/financial-aid/articles/the-31-money-saving-tricks-for-students, dicapai pada 20 Julai 2016.

Felipe, I.J.D.S, Ceribeli, H.B. \& Lana, T.Q, 'Investigating the Level of Financial Literacy of University Students,' RACE, vol. 16/2 (2017): 845-866.

FinAid, 'Defining education - related expenses,' FinAid Page,' http://www. finaid.org/educators/higher-education-expenses.phtml, dicapai pada 1 Mei 2020.

Frijins, B., Gilbert, A. \& Red, A.T., 'Learning by doing: The Role of Financial Experience in Financial Literacy,' Journal of Public Policy, vol. 34 / 1 (2013): 123-154.

Gadot, N., 'Konsep Asnaf Fisabilillah Mengikut Hukum Syarak,' (Kertas kerja, Seminar Pengagihan Zakat di bawah sinf Fisabillilah, Majlis Agama Islam Wilayah Persekutuan, Kuala Lumpur, 9 Jun 2009).

H. Rofie, A. Hamid, Dahaman, Hamid, \& A. Pozin, 'Tinjauan Awal Sorotan Karya Pengetahuan dan Pemahaman Peniaga Kecil Berkaitan Zakat Perniagaan,' (Kertas kerja, 1st Kedah International Zakat Conference, Lembaga Zakat Negeri Kedah, Kedah, 6 Ogos 2019).

Hasrul Hassan, 'Kewajipan Zakat Fitrah seorang perempuan,' https://www. hasrulhassan.com/2014/07/kewajipan-zakat-fitrah-seorang-perempuan. html, dicapai pada 6 Ogos 2020.

Hassan \& M. Nasir., 'Prioritization of Zakat Distribution in Selangor and the Federal Territory of Malaysia: Are They Following the Right Distribution Principles according to Syariah?' Intellectual Discourse, Special Issue (2016): 435-457.

Hassan, An Islamic Paradigm in Economics: Vision and Mission (Kuala Lumpur, Malaysia: Institut Kefahaman Islam Malaysia, 2012).

Hazly Takaful, 'Memahami apa itu insurans dan takaful?'https://hazlytakafulge. wordpress.com/2014/02/16/memahami-apa-itu-insurans-dan-takaful/, dicapai pada 1 Mei 2020.

Ho, Fiona, 'Wedding Loans: The Worst Decision You Could Make,' https:// www.imoney.my/articles/wedding-loans-the-worst-decision-youcould-make, dicapai pada 1 Mei 2020. 
Hung, A. A., Parker, A. M. \& Yoong, J., 'Defining and Measuring Financial Literacy,' Working Paper no. 708 (Santa Monica: Social Science Research Network, 2009).

Ibrāhim Ibn Muhammad al-Bajurī, Hāshiyah al-Bajurī 'ala Sharh al- 'Allāmah Ibn Qașīm al-Ghazzī 'ala Matn Abī Shuja', vol. 2, ed. Mạ̣mūd Șālị̣ al-Hadīd̄̄ (Jeddah: Dār al-Minhāj, 2016),

Ibrahim, M. F., 'Perbandingan Kaedah Kutipan Zakat Harta Harta oleh Institusi Zakat di Negeri-Negeri Utara Semenanjung Malaysia.' (Kertas kerja, 1 st Kedah International Zakat Conference, Lembaga Zakat Negeri Kedah, Kedah, 6 Ogos 2019).

Ibrahim, M.F. \& Sahrim, M., 'Peranan Agihan Zakat sebagai Alat Kewangan Sosial Islam bagi Melangsaikan Hutang Golongan Al-Gharimin di Malaysia,' Labuan e-Journal of Muamalat and Society, vol. 13/1 (2019): 45-53.

Imam al-Ghazali, Penerangan Ilmu yang Dihukumi Sebagai Fardhu Ain, dalam kitab Ihya' Ulumiddin (Jeddah: Darul Minhaj, 2011).

iMoney.my, 'Cagaran dan Penjamin Pinjaman Peribadi', https://www.imoney. my/articles/cagaran-dan-penjamin-pinjaman-peribadi, dicapai pada 1 Mei 2020.

Infopelajar2u, 'Derma siswa melanjutkan pelajaran ke IPT tempatan Zakat Kedah,' https://www.infopelajar2u.com/derma-siswa-melanjutkanpelajaran-ke-ipt-tempatan-zakat-kedah/, dicapai pada 1 Mei 2020.

ITS Education Asia, 'The importance of Business English in Hong Kong,' www.itseducation.asia/business-english.htm, dicapai pada 1 Mei 2020.

Jaafar, N., Abd Ghani, Z, Tibek, S. R., Mohd Nor, A. H, Gunardi, S., Ismail, N. A., Darmi, R., Mat Saad, N. S., Idrus, M. M., Abdullah, H., Ishak, M., Ismail, H., \& Sulaiman, A., 'Cabaran Institusi Pendidikan Pondok Serta Impak Terhadap Pembentukan Diri Pelajar,' Journal of Islamic, Social, Economics and Development (JISED), vol. 2/6 (2017): 223 - 235.

Jabatan Bantuan Guaman, 'Nafkah Orang Islam,' http://www.jbg.gov.my/ images/doc/risalah/nafkah-org-islam.pdf, dicapai pada 6 Ogos 2020.

Jabatan Kemajuan Islam Malaysia (JAKIM), 'e-Muamalat: Portal Rasmi Muamalat dan Kewangan Islam,' Jabatan Kemajuan Islam Malaysia (JAKIM)', http://e-muamalat.islam.gov.my/ms/soalan-lazim/takaful, dicapai pada 26 September 2019. 
Jabatan Perangkaan Malaysia, 'Kaji Selidik Kemudahan Asas dan Pendapatan Isi Rumah 2019' https://www.dosm.gov.my/v1/index.php?r=column/pd fPrev\&id=cE13dXFSRFVQL2IrTUhJNE5vRXRXZz09, dicapai pada 1 Ogos 2020.

Jomurusduit.com., 'Bila perlu ambil perlindungan Insurans/Takaful,' https:// jomurusduit.com/2016/08/bila-perlu-ambil-perlindungan-insuranstakaful.html, dicapai pada 1 Mei 2020.

Kaizan Nazlan, 'Mahasiswa Islam : Erti Seorang Muslim,' https://www. slideshare.net/kaizan/mahasiswa-islam-erti-seorang-muslim, dicapai pada 9 Ogos 2020.

Kementerian Belia dan Sukan dalam 'Draf Kajian Semula Dasar Belia Negara,' https://www.ippbm.gov.my/jdownloads/Penyelidikan/kajian-literasikomputer-di-kalangan-belia-luar-bandar.pdf, dicapai pada 1 Mei 2020.

Kementerian Kesihatan Malaysia, 'Mengharungi kehidupan di kolej dan universiti,' http://www.myhealth.gov.my/mengharungi-kehidupan-dikolej-dan-universiti/, dicapai pada 1 Mei 2020.

Kiyosaki, Robert T., Increase your financial IQ: Get Smarter with Your Money (New York, USA: Hachetter Book Group, 2008).

Kurniawan, 'Pengertian Mahasiswa menurut para ahli beserta peran dan fungsinya.' https://www.gurupendidikan.co.id/pengertian-mahasiswa/, dicapai pada 1 Mei 2020.

KWSP, 'Finance your higher education: Pursue a brighter future for you or your children,' https://www.kwsp.gov.my/member/withdrawals/partial/ education, dicapai pada 1 Mei 2020.

Lahsasna, A., 'Wealth Purification, CIWM Special Edition 2013-2015, 20-22' https:/www.inceif.org/archive/wp-content/uploads/2018/02/WealthPurification.pdf, dicapai pada 1 Mei 2020.

Lantara, I.W.N \& Kartini, N.K.R., 'Financial Literacy Among University Students: Empirical Evidence from Indonesia,' Journal of Indonesian Economy and Business, vol. 30/3 (2015): 247-256.

Laporan Bank Negara Malaysia 2016, 2017, 2018, 2019. https://www.bnm. gov.my/index.php?ch=en_publication\&pg=en_ar\&lang=en\#tab1, dicapai pada 1 Mei 2020.

Lembaga Zakat Selangor, 'Penerimaan \& Kriteria Penerimaan Zakat'https:// www.zakatselangor.com.my/agihan-zakat/penerima-kriteriapenerimaan-zakat/, dicapai pada 1 Mei 2020. 
Luksander Alexandra., Beres, Daniel., Huzdik, Katalin, \& Nemeth, Erzsebet, 'Analysis of the Factors that Influence the Financial Literacy of Young People Studying in Higher Education,' Public Finance Quarterly, vol. 3 (2014): 220-241.

Lusardi, A. \& S. Mitchell, O. \& Curlo, V., 'Financial Literacy among the Young: Evidence and Implications for Consumer Policy,' The Organisation for Economic Co-operation and Development (OECD) https://www. dartmouth.edu/ alusardi/Papers/Financial_literacy_young.pdf, dicapai pada 1 Mei 2020.

M. Shaarani, A. Z., Ahmad, R., M. Noor, A., \& Muhammad, F., 'Zakat dalam mazhab Shafi'i: Analisis kaedah istinbat hukum.' (Kertas kerja, 1st Kedah International Zakat Conference, Lembaga Zakat Negeri Kedah, Kedah, 6 Ogos 2019).

Mahalingam, 'Saving and investing for a child's education is imperative with ever-rising cost,' https://www.thestar.com.my/business/businessnews/2012/06/02/saving-and-investing-for-a-childs-education-isimperative-with-everrising-cost, dicapai pada 1 Mei 2020.

Malaysian Communications and Multimedia Commission's (MCMC), '2018 Internet Users Survey' https://www.mcmc.gov.my/skmmgovmy/media/ General/pdf/Internet-Users-Survey-2018.pdf, dicapai pada 1 Mei 2020.

Malaysian Takaful Association, 2017 Report (Kuala Lumpur: Malaysian Takaful Association, 2017).

Mat Hassan, S. H., 'Kongsi nikmat kemewahan capai kebahagiaan akhirat,' https://www.bharian.com.my/node/54930, dicapai pada 1 Mei 2020.

Md Sapir, Ana Shakirah, 'Islamic Financial Literacy among Malaysian Undergraduates,' (Master Dissertation, Faculty Business and Accountancy, University of Malaya, Kuala Lumpur, 2016).

Md Yusof, S., M. Tahir, R. and Othman, A., 'Permasalahan golongan fakir dan miskin: Kajian dalam kalangan penerima bantuan zakat di Kedah.' (Kertas kerja, 1st Kedah International Zakat Conference, Lembaga Zakat Negeri Kedah, Kedah, 6 Ogos 2019).

Md. Jaafar, F. \& Osman, R., 'Pemerkasaan agihan zakat: Medium pembangunan resiliensi asnaf muallaf.' (Kertas kerja, 1st Kedah International Zakat Conference, Lembaga Zakat Negeri Kedah, Kedah, 6 Ogos 2019).

Md.Sapir@Md.Shafik, A. and Wan Ahmad, W., 'Financial literacy among Malaysian Muslim undergraduates', Journal of Islamic Accounting and Business Research. ahead-of-print (2020). 
Merdeka.com., 'Fakta-fakta dunia dikuasai hanya oleh segelintir orang kaya,' https://www.merdeka.com/uang/fakta-fakta-dunia-dikuasai-hanyaoleh-segelintir-orang-kaya.html, dicapai pada 1 Mei 2020.

Mikail, D.S.A., \& Adekunle, S.S., 'Sustainable Financial Inclusion: A Fiqh Analysis of Zakat,' (Kertas kerja, 1st Kedah International Zakat Conference, Lembaga Zakat Negeri Kedah, Kedah, 6 Ogos 2019).

Ministry of Finance (MOF), Malaysian Economic Outlook 2019 (Putrajaya, Malaysia: Ministry of Finance, 2019).

Mohd Fauzi, Puteri, Abd Rashid, Khairuddin, Sharkawi, Azila, Hasan, Sharina, Aripin, Srazali, \& Arifin, Muhammad., 'Takaful: A review on performance, issues and challenges in Malaysia,' Journal of Scientific Research and Development, vol. 3/4 (2016): 71-76.

Mohd Khairil Ashraf \& Wan Mohd Saipuddin, 'Bijak Mengurus Wang,' (Seminar organized by University Malaya Muslim Undergraduate Students Association at BS1, Academic of Islamic Studies, University Malaya, Kuala Lumpur, 30 November 2016).

Mohd Shahrizal Nasir, ' Keperluan, bukan pilihan,' https://www.hmetro.com. my/addin/2020/01/536781/keperluan-bukan-pilihan, dicapai pada 10 Ogos 2020.

Mohd. Ali, M.N., Hairunnizam, W. \& Nor Ghani, M.N., 'Kesedaran Membayar Zakat Pendapatan Kakitangan Professional: Kajian kes di UKM,' (Kertas kerja, Seminar Kebangsaan Dasar Awam dalam Era Globalisasi: Penilaian Semula Ke Arah Pemantapan Strategi, Bangi, Selangor, 16-17 September 2003).

Muhammad bin Aḥmad al-Ṣāliḥ, al-Takāful al-Ijtimā'î fì al-Sharī'ah alIslāmiyyah (Arab Saudi: Kerajaan Arab Saudi, 1993).

Muḥammad Ibn 'Īsā Ibn Sawrah al-Tirmidh̄̄, Sunan Tirmidh̄̄, vol. 4 (Bayrūt: Dār al-Gharb al-Islāmī, 1998).

Muhammad Ibn Ismā'il al-Bukhārī, Ṣaḥ̄ḥ al-Bukhārī, vol. 1 (Bayrūt: Dār Ṭawq al-Najāh, 1422H).

Muḥammad Riḍā al-Muẓaffar, al-Manțiq (Lubnan: Dār al-Ta'rīfli al-Maṭbū'āt, 2006).

Muḥammad Ṭayyib bin 'Abd al-Majib Ibn Kiran, Sharh Muqaddimah alMurshìd al-Mu 'in fì al- 'Aqīdah (t.t.p.: Maṭba'ah al-Tawfiq, t.t.).

Nasihat kewangan, '4 langkah mudah untuk mencipta dana pendidikan anak-anak tanpa melibatkan pinjaman,' https://www.nasihatkewangan. com/2020/03/4-langkah-mudah-untuk-mencipta-dana.html, dicapai pada 1 Mei 2020. 
Nizār Hammadī, al-Ta 'rīfāt al-Zarrūqiyyah li al-Haqā ’iq al-Sūfiyyah (Tunisia: Dār al-Imām Ibn 'Arafah, 2017).

Norvilitis \& MacLean, 'The Role of Parents in College Students' Financial Behaviours and Attitude,' Journal of Economic Psychology, vol. 31 (2010): 55-63.

Patho Rohman, 'Amalan terdahulu punca PTPTN berhutang RM 40 billion,' https://www.bharian.com.my/berita/nasional/2019/05/564646/amalanterdahulu-punca-ptptn-berhutang-rm40-bilion, dicapai pada 1 Mei 2020.

Perbadanan Insurans Deposit Malaysia, 'Perlindungan bagi Sistem Perlindungan Manfaat Takaful dan Insurans,' https://www.pidm.gov.my/ ms-my/for-public/takaful-and-insurance-benefits-protection-system/ coverage-for-tips/, dicapai pada 1 Mei 2020.

Perbadanan Tabung Pendidikan Tinggi Nasional (PTPTN), 'Pembiayaan PTPTN bukan Riba', https://www.ptptn.gov.my/images/fail/siaran media/2016/sm_pembiayaan_ptptn_bkn_riba.pdf, dicapai pada $2 \overline{3}$ September 2019.

PISA. PISA 2012 Financial Literacy Assessment Framework. 12 (Paris, France: OECD Publishing, 2012).

Pusat Pungutan Zakat (PPZ MAIWP), Laporan Kewangan Zakat 2005-2017 (Kuala Lumpur, Malaysia: PPZ MAIWP, 2019)

Puspita, G. \& Isnalita, 'Financial Literacy: Pengetahuan, Kepercayaan Diri dan Perilaku Keuangan Mahasiswa Akuntasi,' Riset \& Jurnal Akuntansi, vol. 3/2 (2019): 117-128.

PWC, 'Developing a Global Financial Centre for Social Impact Investment Research Report City of London Corporation,' www.cityoflondon.gov. uk/economicresearch, dicapai pada 1 Mei 2020.

Qasim, M.I., 'The Role of Zakat in Poverty Alleviation in Nigerian Society' (Kertas kerja, 1st Kedah International Zakat Conference, Lembaga Zakat Negeri Kedah, Kedah, 6 Ogos 2019).

Remund, David. L., 'Financial Literacy Explicated: The Case for a Clearer Definition in an Increasingly Complex Economy,' The Journal of Consumer Affairs, vol. 44/1 (2010): 276-295.

Ringgitplus.com., 'Best Personal Loans, https://ringgitplus.com/en/ personal-loan/?utm_source=google $\& u t m \_$medium $=$cpa\&utm content $=348216903302 \& u t m \_$term $=\mathrm{debt} \% 20$ consolidation $\& u \mathrm{tm}_{-}$ campaign $=$ my-s-peln-gen $\&$ gclid $=$ Cj0KCQjwtLT1BRD9ARIs $\bar{A}$ MH3BtWYtQcEnUXwG3hE0fjCaYOu6R7rJXDzyIOM0B9ZkrWkeQxhf3gyv4aAiwDEALw_wcB, dicapai pada 1 Mei 2020. 
Robb, Barbiaz \& Woodyard, 'The Demand for Financial Professionals' Advice: The Role of Financial Knowledge, Satisfaction, and Confidence,' Financial Service Review, vol. 21 (2012): 291-305.

Robb, C. A. \& Sharpe, D. L., 'Effect of Personal Financial Knowledge on College Students' Credit Card Behavior,' Journal of Financial Counseling and Planning, vol. 20/1 (2009): 25-43.

Rosele, M. I., Abdullah, L. \& Md. Ariffin, F., \& Isamail, M.Z., 'Konflik Hukum Zakat Pendapatan: Satu Penilaian,' Labuan e-Journal of Muamalat and Society, vol. 11 (2017): 13-19.

Rosele, M.I., 'Prinsip Al-Nama' dan Kedudukannya Zakat Semasa: Satu Tinjauan,' dalam Menelusuri isu-isu Kontemporari Zakat, ed. Md. Jani, R., Paizin, M. N., Abdullah, L., \& Rosele, M.I. (Kuala Lumpur: Pusat Pungutan Zakat, 2016), 1-15.

Sabri, B. \& Zainuddin, N.A., 'Kos Sara Hidup Mahasiswa UPM,' Jurnal Pengguna, vol. 8/29 (2018): 117-135.

Sabri, F., C. Cook \& Clinton G., 'Financial well-being of Malaysian college students,' Asian Education and Development Studies, 1/2 (2012): 153170.

Senawi, A. R. \& Mat Isa, M.P., 'Analisis Emas sebagai Penanda Aras Nisab Zakat di Malaysia,' dalam Menelusuri Isu-Isu Kontemporari Zakat, ed. Md. Jani, R., Paizin, M. N., Abdullah, L., \& Rosele, M.I. (Kuala Lumpur: Pusat Pungutan Zakat, 2016), 203-222.

Shams al-Dīn Muḥammad al-Ramlī, Nihāyah al-Muḥtāj ila Sharḥ al-Minhaj, vol. 8 (Bayrūt: Dār al-Fikr, 1984).

Sharifah Zahidah, 'Coretan spontan tentang Syria,' https://kraj1zlwu7. cloudfront.net/budaya-suami-di-syria-beli-keperluan-dapur-adalahketua-keluarga-bukan-isteri/, dicapai pada 6 Ogos 2020.

Shim, S., Xiao, J.J., Barber, B.L. \& Lyons, A.C., 'Pathways to Life Success: A Conceptual Model of Financial Well-being for Young Adults,' Journal of Applied Developmental Psychology, vol. 30/6 (2009): 708-723.

Sinar Harian, 'Masalah Kewangan Punca Kes Cerai Tinggi,' https://www. sinarharian.com.my/article/29843/berita/Nasional/Masalah-kewanganpunca-kes-cerai-tinggi, dicapai pada 1 Mei 2020.

Student Involvement University of Nebraska-Lincoln, 'Your Vibrant Hub!' https://communityvitality.unl.edu/create-vibrant-communities, dicapai pada 1 Mei 2020. 
Tajuddin, T.S., Shamsuddin, N., \& Mat Nor, F., 'Current Methods of Business Zakat Accounting in Malaysia,' (Paper presented at the $4^{\text {th }}$ International Conference on Management and Muamalah 2017, 7-8 November 2017, Selangor, Malaysia).

Taufiq Yap, 'Islam Angkat Martabat, Hak Wanita,' https://www.hmetro.com. my/addin/2019/03/438338/islam-angkat-martabat-hak-wanita, dicapai pada 1 Mei 2020.

The Banker, Top Islamic Financial Institutions (Dubai: Divanna, J. \& King, James, 2015).

The Consumer Financial Protection Bureau, 'Measuring Financial WellBeing: A Guide to Using the CFPB Financial Well-Being Scale,' https:// www.consumerfinance.gov/data-research/research-reports/financialwell-being-scale/, dicapai pada 13 Ogos 2016.

The Organisation for Economic Co-operation and Development (OECD), 'Who we are,' https://www.oecd.org/about/, dicapai pada 6 Ogos 2020.

Thilinadan, 'Culas bayar PTPTN khianati pelajar B40,' https://www.bharian. com.my/kolumnis/2019/07/587459/culas-bayar-ptptn-khianatipelajar-b40, dicapai pada 1 Mei 2020.

Thomson Reuters, Islamic Social Finance Report 2014 (Ontario, Canada: Thomson Reuters, 2014).

Trend Remaja, 'Definisi atau Pengertian Trend' https://remajanew.blogspot. com/2015/01/Definisi-pengertian-trend.html, dicapai pada 1 Mei 2020.

USAID INDONESIA, 'Analysis of the current situation of Islamic Formal Junior Secondary Education in Indonesia,' http://datatopics.worldbank. org/hnp/files/edstats/IDNdprep07.pdf, dicapai pada 1 Mei 2020.

W. Deraman, W.J. \& Ab. Rahaman, 'Takaful Urus Risiko Ikut Prinsip Syariah,' https://www.bharian.com.my/rencana/agama/2019/03/544195/takafulurus-risiko-ikut-prinsip-syariah, dicapai pada 1 Mei 2020.

W. Hassan, W. Z., Jamsari, E.A., Muslim, N., Alias, J., Zulkifli, M. \& Ahmad, M.Y., 'The Dynamics of Zakat Distribution According to Shafii School of Law in Fatwas of Terengganu State,' International Journal of Civil Engineering and Technology, vol. 9/1 (2018): 771-783.

W. Mahmud, 'Pengurusan hutang yang efektif,' http://e-muamalat.islam.gov. my/images/pdf-bahan-ilmiah/pengurusan_hutang_yang_efektif_baru. pdf, dicapai pada 1 Mei 2020.

Wahid, H., Mohd Noor, M. A. \& Ahmad, S., 'Kesedaran Membayar Zakat: Apakah Faktor Penentunya?' International Journal of Management Studies, vol. 12/2 (2005): 171-189. 
Wan Ahmad, Wan Marhaini \& Md Sapir, Ana Shakirah, 'Women and Zakat on Banking Deposits,' dalam Muslim Women's Inspiration Towards Sustainable Development Goals, ed. Nurhafilah Musa \& Najah Nadiah Amran (Selangor: Persatuan Ulama Malaysia, 2019), 305-330.

Yakob, R., Janor, H., \& Khamis, N.A., 'Tahap Literasi Kewangan dalam Kalangan Pelajar Universiti Awam: Kajian di Universiti Kebangsaan Malaysia,' Jurnal Personalia Pelajar, vol. 18/1 (2015): 75-88.

Zafar U. Ahmed., Ishak Ismail., M. Sadiq Sohail., Ibrahim Tabsh \& Hasbalaila Alias, 'Malaysian Consumers' Credit Card Usage Behavior,' Asia Pacific Journal of Marketing and Logistics, vol. 22/4 (2010): 528-544.

\section{Statut}

Akta Takaful 1984.

\section{Temu bual}

Nur Farzielayati Mohamed Nawawi (Perunding Takaful, Takaful Ikhlas Berhad), dalam temu bual beliau bersama penulis pada 15 Oktober 2016. 
Jurnal Syariah, Jil. 28, Bil. 2 (2020) 189-262 